Prepared in cooperation with the Nebraska Department of Natural Resources, and the Upper Elkhorn, Lower Elkhorn, Upper Loup, Lower Loup, Middle Niobrara, Lower Niobrara, Lewis and Clark, and Lower Platte North Natural Resources Districts

\title{
Simulation of Ground-Water Flow and Effects of Ground- Water Irrigation on Base Flow in the Elkhorn and Loup River Basins, Nebraska
}

Scientific Investigations Report 2008-5143 
Cover: Three-dimensional shaded relief of streams draining the Sand Hills area of Nebraska. 


\section{Simulation of Ground-Water Flow and Effects of Ground-Water Irrigation on Base Flow in the Elkhorn and Loup River Basins, Nebraska}

By Steven M. Peterson, Jennifer S. Stanton, Amanda T. Saunders, and Jesse R. Bradley

Prepared in cooperation with the Nebraska Department of Natural Resources, and the Upper Elkhorn, Lower Elkhorn, Upper Loup, Lower Loup, Middle Niobrara, Lower Niobrara, Lewis and Clark, and Lower Platte North Natural Resources Districts

Scientific Investigations Report 2008-5143 


\section{U.S. Department of the Interior DIRK KEMPTHORNE, Secretary}

\section{U.S. Geological Survey \\ Mark D. Myers, Director}

\section{U.S. Geological Survey, Reston, Virginia: 2008}

For product and ordering information:

World Wide Web: http://www.usgs.gov/pubprod

Telephone: 1-888-ASK-USGS

For more information on the USGS — the Federal source for science about the Earth, its natural and living resources, natural hazards, and the environment:

World Wide Web: http://www.usgs.gov

Telephone: 1-888-ASK-USGS

Any use of trade, product, or firm names is for descriptive purposes only and does not imply endorsement by the U.S. Government.

Although this report is in the public domain, permission must be secured from the individual copyright owners to reproduce any copyrighted materials contained within this report.

Suggested citation:

Peterson, S.M., Stanton, J.S., Saunders, A.T., and Bradley, J.R., 2008, Simulation of ground-water flow and effects of ground-water irrigation on base flow in the Elkhorn and Loup River Basins, Nebraska: U.S. Geological Survey Scientific Investigations Report 2008-5143, 65 p. 


\section{Contents}

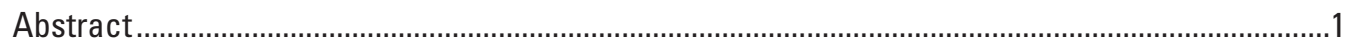

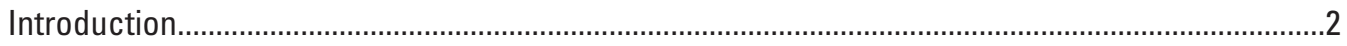

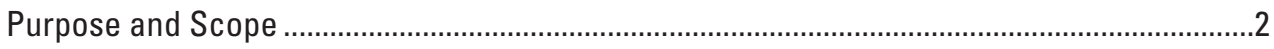

Study Area Description ................................................................................................

Water Use and Management..................................................................................

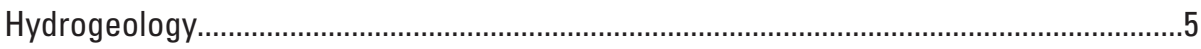

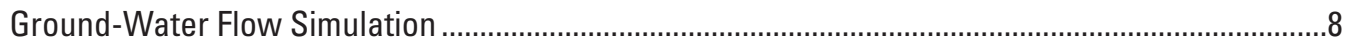

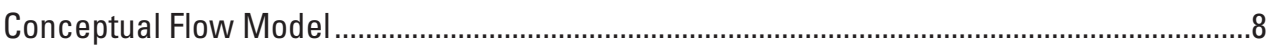

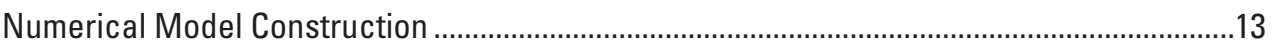

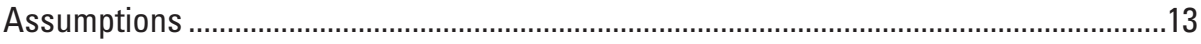

Simulation Periods ...................................................................................................

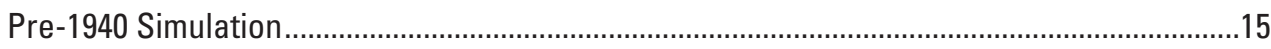

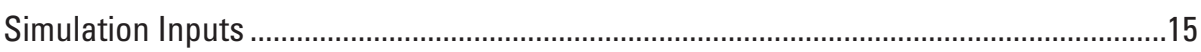

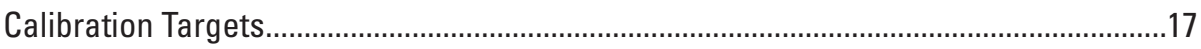

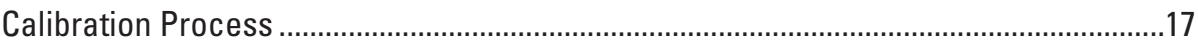

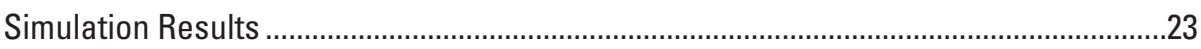

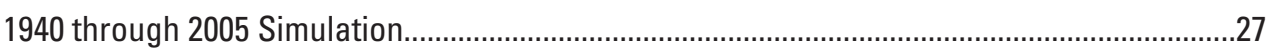

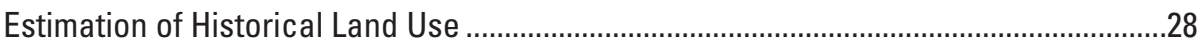

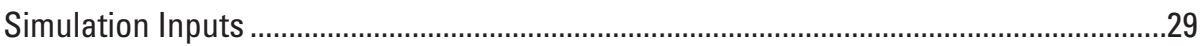

Calibration Targets.................................................................................................

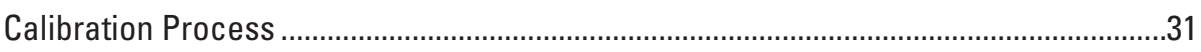

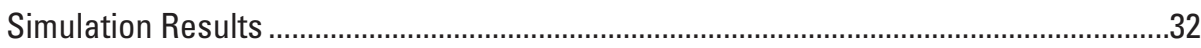

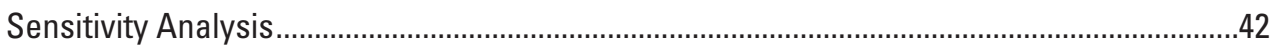

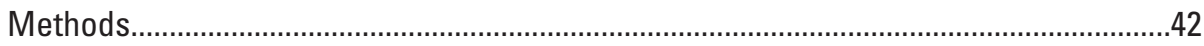

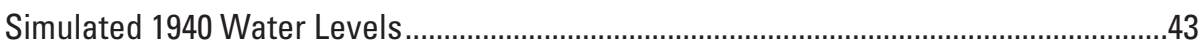

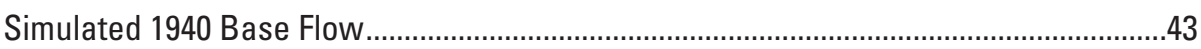

Simulated 1940 through 2005 Water-Level Changes ........................................................45

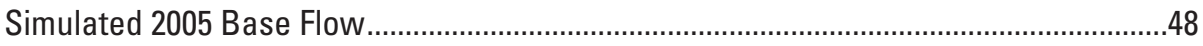

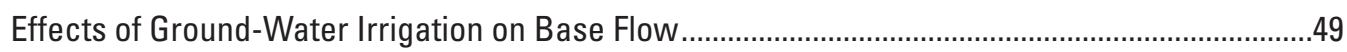

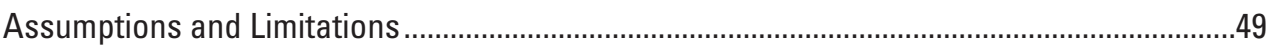

Difference in Simulated Base Flow Caused by Ground-Water Irrigation ...............................50

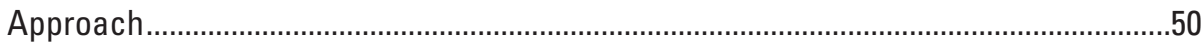

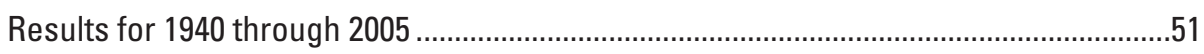

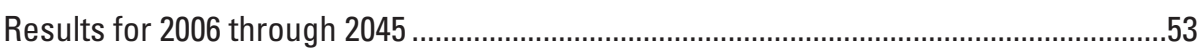

Base-Flow Depletion Percentage for a 50-Year Period........................................................58

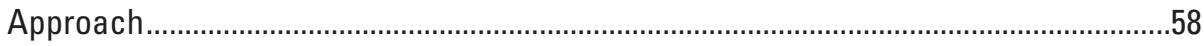

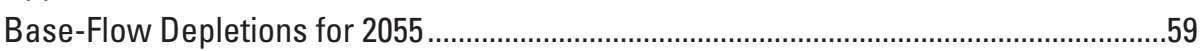

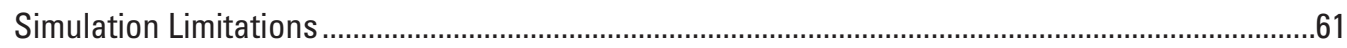

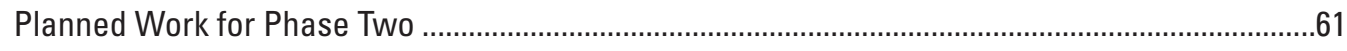

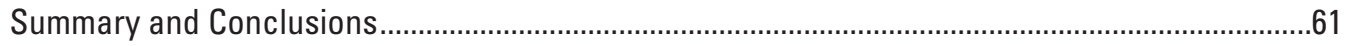

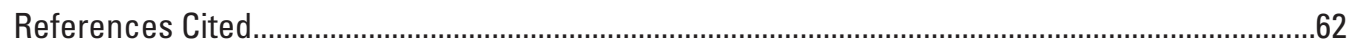




\section{Figures}

1-15. Maps showing:

1. Location of the Elkhorn and Loup River Basins study area in Nebraska, including major streams and Natural Resources Districts ......................................................................

2. Topographic regions in the Elkhorn and Loup River Basins, Nebraska ........................... 4

3. Mean annual 1961-90 precipitation and mean annual 1946-55 lake evaporation in the Elkhorn and Loup River Basins, Nebraska ...

4. Elevation of the base of the water-table aquifer, Elkhorn and Loup River Basins, Nebraska

5. Maximum saturated thickness of the water-table aquifer, using 1979 and 1995 watertable contours, and areas with little or no aquifer thickness, Elkhorn and Loup River Basins, Nebraska...

6. Configuration of water-table elevation contours in the Elkhorn and Loup River Basins, Nebraska, 1995

7. Conceptual flow model of the Elkhorn and Loup River Basins, Nebraska..

8. Canal systems and irrigation districts in the Elkhorn and Loup River Basins, Nebraska

9. Distribution of water-level measurements used to calibrate the pre-1940 simulation, and distribution of streamflow-gaging stations with base-flow estimates used to calibrate the pre-1940 simulation and 1940 through 2005 simulation, Elkhorn and Loup River Basins, Nebraska..

10. Calibrated hydraulic conductivity, Elkhorn and Loup River Basins, Nebraska ...............20

11. Calibrated pre-1940 recharge from precipitation, Elkhorn and Loup River Basins, Nebraska.

12. Calibrated streambed conductance, Elkhorn and Loup River Basins, Nebraska...........22

13. Calibrated maximum annual evapotranspiration rates, Elkhorn and Loup River Basins, Nebraska.

14. Differences between measured water level and simulated 1940 water level, Elkhorn and Loup River Basins, Nebraska.

15. Simulated 1940 water-level elevation contours and published 1979 water-level elevation contours, Elkhorn and Loup River Basins, Nebraska.

16-17. Graphs showing:

16. Yearly estimated pumpage for corn, soybeans, and total pumpage, Elkhorn and Loup River Basins, Nebraska, 1940 through 2005

17. Estimated recharge from canal and lateral seepage, 1940 through 2005, Elkhorn and Loup River Basins, Nebraska.

18-24. Maps showing:

18. Differences between measured and simulated water-level changes, Elkhorn and Loup River Basins, Nebraska, 1945-55

19. Differences between measured and simulated water-level changes, Elkhorn and Loup River Basins, Nebraska, 1955-65.

20. Differences between measured and simulated water-level changes, Elkhorn and Loup River Basins, Nebraska, 1965-75

21. Differences between measured and simulated water-level changes, Elkhorn and Loup River Basins, Nebraska, 1975-85.

22. Differences between measured and simulated water-level changes, Elkhorn and Loup River Basins, Nebraska, 1985-95

23. Differences between measured and simulated water-level changes, Elkhorn and Loup River Basins, Nebraska, 1995-2005... 
24. Differences between measured and simulated water-level changes, Elkhorn and Loup River Basins, Nebraska, 1945-2005.

25. Map and hydrographs showing calibration results for the 1940 through 2005 simulation, Elkhorn and Loup River Basins, Nebraska

26-29. Graphs showing:

26. Sensitivity of the simulated 1940 water levels to changes in simulation inputs, Elkhorn and Loup River Basins, Nebraska

27. Sensitivity of the simulated 1940 base flow of selected streams to changes in simulation inputs, Elkhorn and Loup River Basins, Nebraska.

28. Sensitivity of the simulated 1940 through 2005 water-level changes to changes in simulation inputs, Elkhorn and Loup River Basins, Nebraska

29. Sensitivity of the 2005 simulated base flow of selected streams to changes in simulation inputs, Elkhorn and Loup River Basins, Nebraska..

30. Map showing zones used for analysis of the effects of ground-water irrigation on base flow, Elkhorn and Loup River Basins, Nebraska.

31-34. Graphs showing:

31. Cumulative effects of ground-water irrigation on simulated base flow, Elkhorn and Loup River Basins, Nebraska, 1940 through 2005.

32. Annual rate of effects of ground-water irrigation on simulated base flow, Elkhorn and Loup River Basins, Nebraska, 1940 through 2005.

33. Cumulative effects of ground-water irrigation on simulated base flow, Elkhorn and Loup River Basins, Nebraska, 2006 through $2045 .$.

34. Annual rate of effects of ground-water irrigation on simulated base flow, Elkhorn and Loup River Basins, Nebraska, 2006 through 2045.

35. Map showing base-flow depletion percentage for the Elkhorn and Loup River Basins, simulated for 2006 through 2055

\section{Tables}

1. Estimated recharge from canal and lateral seepage during the pre-1940 simulation, Elkhorn and Loup River Basins, Nebraska

2. Estimated minimum and maximum base flow compared with simulated 1940 and 2005 base flow, Elkhorn and Loup River Basins, Nebraska

3. Simulated ground-water budget for the pre-1940 simulation, Elkhorn and Loup River Basins, Nebraska.....

4. Statistical summary of calibration for selected time periods of the 1940 through 2005 simulation, Elkhorn and Loup River Basins, Nebraska.

5. Average annual simulated ground-water budget for the 1940 through 2005 simulation, Elkhorn and Loup River Basins, Nebraska

6. Sensitivity of simulated 1940 water levels and 1940 through 2005 water-level changes to changes in simulation inputs, Elkhorn and Loup River Basins, Nebraska.

7. Sensitivity of simulated 1940 and 2005 base flow to changes in simulation inputs, Elkhorn and Loup River Basins, Nebraska.

8. Comparison of simulated base flow for simulations with and without ground-water irrigation, 2005, 2045, 2055, Elkhorn and Loup River Basins, Nebraska..... 


\section{Conversion Factors}

\begin{tabular}{|c|c|c|}
\hline Multiply & By & To obtain \\
\hline \multicolumn{3}{|c|}{ Length } \\
\hline inch (in.) & 2.54 & centimeter $(\mathrm{cm})$ \\
\hline inch (in.) & 25.4 & millimeter $(\mathrm{mm})$ \\
\hline foot (ft) & 0.3048 & meter $(\mathrm{m})$ \\
\hline mile (mi) & 1.609 & kilometer $(\mathrm{km})$ \\
\hline yard $(y d)$ & 0.9144 & meter $(\mathrm{m})$ \\
\hline \multicolumn{3}{|c|}{ Area } \\
\hline acre & 4,047 & square meter $\left(\mathrm{m}^{2}\right)$ \\
\hline acre & 0.004047 & square kilometer $\left(\mathrm{km}^{2}\right)$ \\
\hline square foot $\left(\mathrm{ft}^{2}\right)$ & 0.09290 & square meter $\left(\mathrm{m}^{2}\right)$ \\
\hline square inch $\left(\mathrm{in}^{2}\right)$ & 6.452 & square centimeter $\left(\mathrm{cm}^{2}\right)$ \\
\hline square mile $\left(\mathrm{mi}^{2}\right)$ & 2.590 & square kilometer $\left(\mathrm{km}^{2}\right)$ \\
\hline \multicolumn{3}{|c|}{ Volume } \\
\hline gallon (gal) & 3.785 & liter $(\mathrm{L})$ \\
\hline million gallons (Mgal) & 3,785 & cubic meter $\left(\mathrm{m}^{3}\right)$ \\
\hline cubic foot $\left(\mathrm{ft}^{3}\right)$ & 28.32 & cubic decimeter $\left(\mathrm{dm}^{3}\right)$ \\
\hline cubic foot $\left(\mathrm{ft}^{3}\right)$ & 0.02832 & cubic meter $\left(\mathrm{m}^{3}\right)$ \\
\hline cubic yard $\left(\mathrm{yd}^{3}\right)$ & 0.7646 & cubic meter $\left(\mathrm{m}^{3}\right)$ \\
\hline acre-foot (acre-ft) & 1,233 & cubic meter $\left(\mathrm{m}^{3}\right)$ \\
\hline \multicolumn{3}{|c|}{ Flow rate } \\
\hline acre-foot per day (acre-ft/d) & 0.01427 & cubic meter per second $\left(\mathrm{m}^{3} / \mathrm{s}\right)$ \\
\hline acre-foot per year (acre-ft/yr) & 1,233 & cubic meter per year $\left(\mathrm{m}^{3} / \mathrm{yr}\right)$ \\
\hline foot per second $(\mathrm{ft} / \mathrm{s})$ & 0.3048 & meter per second $(\mathrm{m} / \mathrm{s})$ \\
\hline foot per day $(\mathrm{ft} / \mathrm{d})$ & 0.3048 & meter per day $(\mathrm{m} / \mathrm{d})$ \\
\hline foot per year $(\mathrm{ft} / \mathrm{yr})$ & 0.3048 & meter per year $(\mathrm{m} / \mathrm{yr})$ \\
\hline cubic foot per second $\left(\mathrm{ft}^{3} / \mathrm{s}\right)$ & 0.02832 & cubic meter per second $\left(\mathrm{m}^{3} / \mathrm{s}\right)$ \\
\hline cubic foot per day $\left(\mathrm{ft}^{3} / \mathrm{d}\right)$ & 0.02832 & cubic meter per day $\left(\mathrm{m}^{3} / \mathrm{d}\right)$ \\
\hline gallon per minute (gal/min) & 0.06309 & liter per second $(\mathrm{L} / \mathrm{s})$ \\
\hline gallon per day (gal/d) & 0.003785 & cubic meter per day $\left(\mathrm{m}^{3} / \mathrm{d}\right)$ \\
\hline million gallons per day (Mgal/d) & 0.04381 & cubic meter per second $\left(\mathrm{m}^{3} / \mathrm{s}\right)$ \\
\hline mile per hour $(\mathrm{mi} / \mathrm{h})$ & 1.609 & kilometer per hour $(\mathrm{km} / \mathrm{h})$ \\
\hline \multicolumn{3}{|c|}{ Crop water usage per unit area } \\
\hline inches per year (in/yr) & 25.4 & millimeter $(\mathrm{mm} / \mathrm{yr})$ \\
\hline \multicolumn{3}{|c|}{ Specific capacity } \\
\hline gallon per minute per foot $[(\mathrm{gal} / \mathrm{min}) / \mathrm{ft})]$ & 0.2070 & liter per second per meter $[(\mathrm{L} / \mathrm{s}) / \mathrm{m}]$ \\
\hline \multicolumn{3}{|c|}{ Hydraulic conductivity } \\
\hline foot per day $(\mathrm{ft} / \mathrm{d})$ & 0.3048 & meter per day $(\mathrm{m} / \mathrm{d})$ \\
\hline \multicolumn{3}{|c|}{ Hydraulic gradient } \\
\hline foot per mile ( $\mathrm{ft} / \mathrm{mi})$ & 0.1894 & meter per kilometer $(\mathrm{m} / \mathrm{km})$ \\
\hline \multicolumn{3}{|c|}{ Transmissivity* } \\
\hline foot squared per day $\left(\mathrm{ft}^{2} / \mathrm{d}\right)$ & 0.09290 & meter squared per day $\left(\mathrm{m}^{2} / \mathrm{d}\right)$ \\
\hline
\end{tabular}


Temperature in degrees Celsius $\left({ }^{\circ} \mathrm{C}\right)$ may be converted to degrees Fahrenheit $\left({ }^{\circ} \mathrm{F}\right)$ as follows:

$$
{ }^{\circ} \mathrm{F}=\left(1.8 x^{\circ} \mathrm{C}\right)+32
$$

Temperature in degrees Fahrenheit $\left({ }^{\circ} \mathrm{F}\right)$ may be converted to degrees Celsius $\left({ }^{\circ} \mathrm{C}\right)$ as follows:

$$
{ }^{\circ} \mathrm{C}=\left({ }^{\circ} \mathrm{F}-32\right) / 1.8
$$

Vertical coordinate information is referenced to the National Geodetic Vertical Datum of 1929 (NGVD 29).

Horizontal coordinate information is referenced to the North American Datum of 1983 (NAD 83).

Altitude, as used in this report, refers to distance above the vertical datum.

*Transmissivity: The standard unit for transmissivity is cubic foot per day per square foot times foot of aquifer thickness $\left[\left(\mathrm{ft}^{3} / \mathrm{d}\right) / \mathrm{ft}^{2}\right] \mathrm{ft}$. In this report, the mathematically reduced form, foot squared per day $\left(\mathrm{ft}^{2} / \mathrm{d}\right)$, is used for convenience. 



\title{
Simulation of Ground-Water Flow and Effects of Ground- Water Irrigation on Base Flow in the Elkhorn and Loup River Basins, Nebraska
}

\author{
By Steven M. Peterson, Jennifer S. Stanton, Amanda T. Saunders, and Jesse R. Bradley ${ }^{1}$
}

\section{Abstract}

Irrigated agriculture is vital to the livelihood of communities in the Elkhorn and Loup River Basins in Nebraska, and ground water is used to irrigate most of the cropland. Concerns about the sustainability of ground-water and surfacewater resources have prompted State and regional agencies to evaluate the cumulative effects of ground-water irrigation in this area. To facilitate understanding of the effects of groundwater irrigation, a numerical computer model was developed to simulate ground-water flow and assess the effects of ground-water irrigation (including ground-water withdrawals, hereinafter referred to as pumpage, and enhanced recharge) on stream base flow.

The study area covers approximately 30,800 square miles, and includes the Elkhorn River Basin upstream from Norfolk, Nebraska, and the Loup River Basin upstream from Columbus, Nebraska. The water-table aquifer consists of Quaternary-age sands and gravels and Tertiary-age silts, sands, and gravels. The simulation was constructed using one layer with 2-mile by 2 -mile cell size.

Simulations were constructed to represent the groundwater system before 1940 and from 1940 through 2005, and to simulate hypothetical conditions from 2006 through 2045 or 2055. The first simulation represents steady-state conditions of the system before anthropogenic effects, and then simulates the effects of early surface-water development activities and recharge of water leaking from canals during 1895 to 1940. The first simulation ends at 1940 because before that time, very little pumpage for irrigation occurred, but after that time it became increasingly commonplace. The pre-1940 simulation was calibrated against measured water levels and estimated long-term base flow, and the 1940 through 2005 simulation was calibrated against measured water-level changes and estimated long-term base flow. The calibrated 1940 through 2005 simulation was used as the basis for analyzing hypothetical

${ }^{1}$ Nebraska Department of Natural Resources scenarios to evaluate the effects of ground-water irrigation on stream base flow for 1940 through 2005 and for 2006 through 2045. Simulated base flows were compared for scenarios that alternately did or did not include a representation of the effects of ground-water irrigation. The difference between simulated base flows for the two scenarios represents the predicted effects of ground-water irrigation on base flow.

Comparison of base flows between simulations with ground-water irrigation and no ground-water irrigation indicated that ground-water irrigation has cumulatively reduced streamflows from 1940 through 2005 by 888,000 acre-feet in the Elkhorn River Basin and by 2,273,000 acre-feet in the Loup River Basin. Generally, predicted cumulative effects of ground-water irrigation on base flow were 5 to 10 times larger from 2006 through 2045 than from 1940 through 2005, and were 7,678,000 acre-feet for the Elkhorn River Basin and 14,784,000 acre-feet for the Loup River Basin.

The calibrated simulation also was used to estimate base-flow depletion as a percentage of pumping volumes for a 50-year future time period, because base-flow depletion percentages are used to guide the placement of management boundaries in Nebraska. Mapped results of the base-flow depletion analysis conducted for most of the interior of the study area indicated that pumpage of one additional theoretical well simulated for a future 50-year period generally would result in more than 80 percent depletion when it was located close to the stream, except in areas where depletion was partly offset by reduced ground-water discharge to evapotranspiration in wetland areas. In many areas, depletion for the 50 -year future period composed greater than 10 percent of the pumped water volume for theoretical wells placed less than 7 or 8 miles from the stream, though considerable variations existed because of the heterogeneity of the natural system represented in the simulation.

For a few streams, predicted future simulated base flows declined substantially. In two streams, the simulated results indicated that a gaining stream in 2005 would be a losing stream in 2055. For three streams simulated base flows in 2055 were absent. No further base-flow depletion occurred once simulated base flow was absent; therefore, base-flow 
depletion as a percentage of the volume pumped more than 50 years declined from the time the stream went dry until the end of the analysis period. Additional depletion as a percentage of pumping would be expected if base flow was present through 2055.

\section{Introduction}

In central and eastern Nebraska, the Elkhorn and Loup Rivers provide surface-water flows for irrigation, recreation, hydropower production, and aquatic life. In addition, outflows of the Elkhorn and Loup Rivers merge with the Platte River near Waterloo, Nebraska, and Columbus, Nebraska (fig. 1), respectively, and support in-stream flow appropriations (such as Nebraska Game and Parks Commission In-Stream Appropriation A-17331 (Nebraska Department of Natural Resources, 2008). Outflows from the Elkhorn and Loup Rivers also recharge the aquifer used by large municipal water systems that pump ground water near the Platte River. Pumpage for irrigation, in turn, is vital to agricultural productivity, and hence the livelihood, of the communities in the ElkhornLoup Model study area (fig. 1). Recent drought (2000-06) has amplified concerns about the long-term sustainability of surface- and ground-water resources in the area, as well as concerns about the effect of ground-water irrigation on streamflow. Further, newly adopted state legislation requires a sustainable balance between long-term water supplies and uses of surface and ground water (Nebraska Department of Natural Resources, 2007). Thus, the U.S. Geological Survey (USGS), the Nebraska Department of Natural Resources (NDNR), and the Upper Elkhorn, Lower Elkhorn, Upper Loup, Lower Loup, Middle Niobrara, Lower Niobrara, Lewis and Clark, and Lower Platte North Natural Resources Districts (NRDs) (collectively referred to hereinafter as ELM NRDs) agreed to cooperatively study water resources in these basins. The Elkhorn-Loup Model (ELM) study area covers approximately 30,800 square miles $\left(\mathrm{mi}^{2}\right)$, and extends from the Niobrara River in the north to the Platte River in the south (fig. 1). The western boundary coincides roughly with the western boundary of the Upper Loup NRD, and the eastern boundary coincides roughly with the approximate location of the westernmost extent of glacial till in eastern Nebraska (Conservation and Survey Division, 2005d). The study will assist NDNR and the ELM NRDs in developing long-term strategies for management of hydrologically connected water supplies.

The goals of the study were to construct and calibrate a regional ground-water flow simulation of the study area, and to use the simulation as a tool to assess the past and future effects of ground-water irrigation on ground-water discharge to streams (hereinafter referred to as base flow). The study is anticipated to proceed in two phases. Phase one, documented in this report, focused mainly on using largely pre-existing data to develop a regional ground-water flow simulation. Phase two is planned to focus on refining the ground-water flow simulation using newly collected data and supporting analyses performed in 2007 and 2008. Both phases are intended to provide information that will assist state and regional agencies with water management efforts.

\section{Purpose and Scope}

The purpose of this report is to document the methodology and results of a simulation of ground-water flow and effects of ground-water irrigation on base flow in the ELM area at the completion of its first phase. The goal of the ELM project was to study surface- and ground-water resources in the Elkhorn River Basin upstream from Norfolk, Nebraska, and the Loup River Basin upstream from Columbus, Nebraska (fig. 1). The report describes the construction and calibration of the phase one regional ground-water flow simulation for the study area. Results from simulating hypothetical scenarios of past and future periods for conditions with and without ground-water irrigation are presented and compared. Differences in simulated base flows are interpreted as the effects of ground-water irrigation. Base-flow depletion for a 50-year period is calculated and presented as a percentage of well pumping volumes.

\section{Study Area Description}

About 60 percent of the Elkhorn-Loup Model area is overlain by the Nebraska Sand Hills (including Sand Hills lakes) (fig. 2), the largest sand-dune area in the Western Hemisphere (Keech and Bentall, 1971). The Sand Hills consist of various types of sand dunes, mostly stabilized with grasses, frequently with inter-dunal lakes. Soils in the Sand Hills are coarser-grained than in the rest of the ELM area, providing "a far greater rate of recharge than in any other upland area of comparable size in the High Plains region" (Keech and Bentall, 1971). Land in the Sand Hills is largely either undeveloped or used only for grazing livestock; row-crop agriculture is uncommon (Patti Dappen, Center for Advanced Land Management Information Technologies (CALMIT), University of Nebraska-Lincoln, written commun., 2006).

Other topographic regions present in the area are wet meadows and marsh plains, loess hills, river valleys, transitional sandy plains, dissected loess plains, plains, and river breaks (U.S. Environmental Protection Agency, 2003). Areas classified as river valleys or plains typically are flat or gently sloping, and mostly are used for row-crop agriculture.

Major streams in the area are the Elkhorn River and its tributaries upstream from Norfolk, Nebraska, and the Loup River and its tributaries upstream from Columbus, Nebraska (fig. 1). The part of the Elkhorn River Basin in the study area is approximately 2,700 $\mathrm{mi}^{2}$ in size; the Elkhorn River flows from west-northwest to east-southeast, draining wet meadows, plains, and marshy plains east of the Sand Hills. The Loup River Basin within the study area is approximately $14,500 \mathrm{mi}^{2}$ in size and includes numerous large tributary streams (such as 


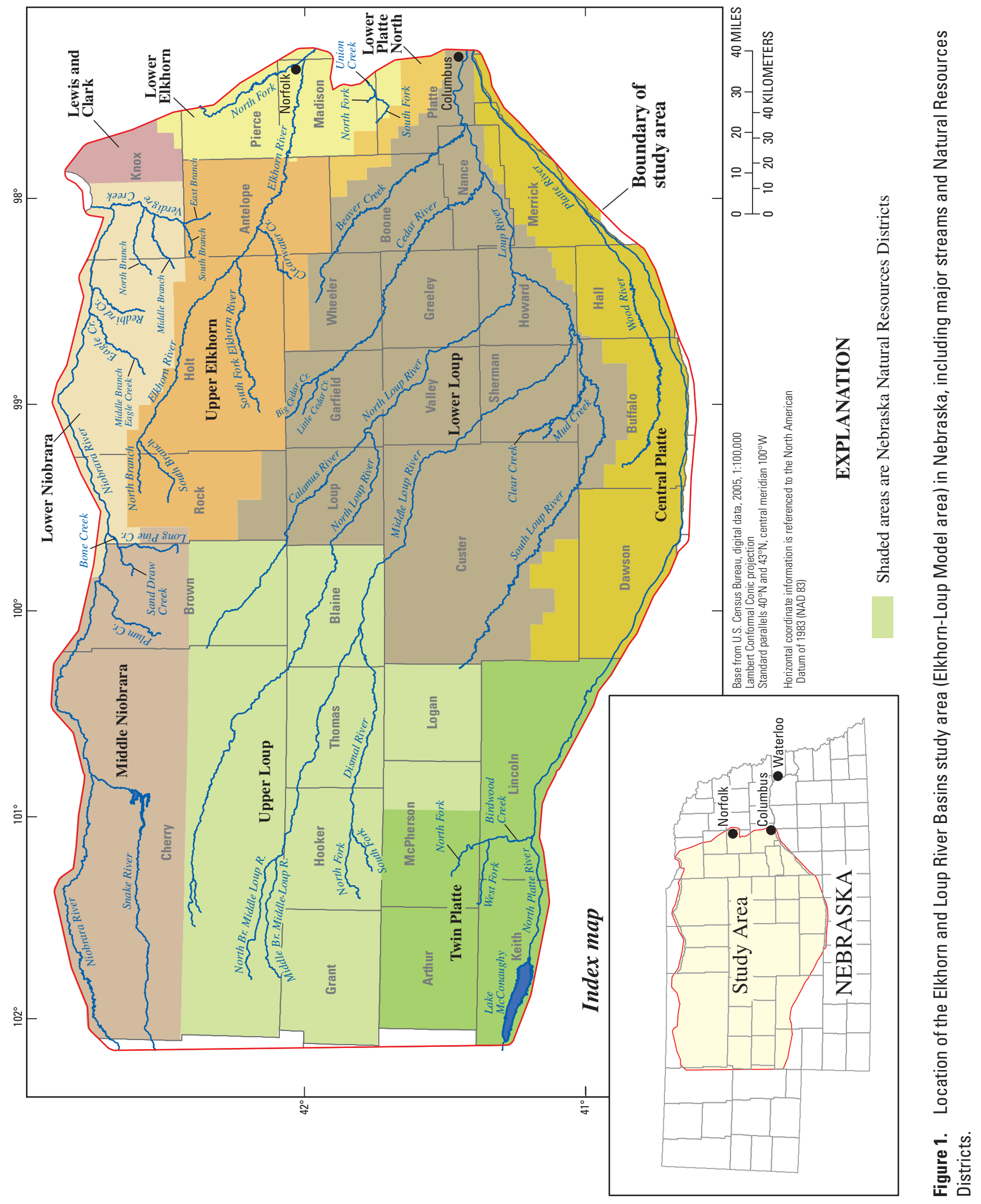




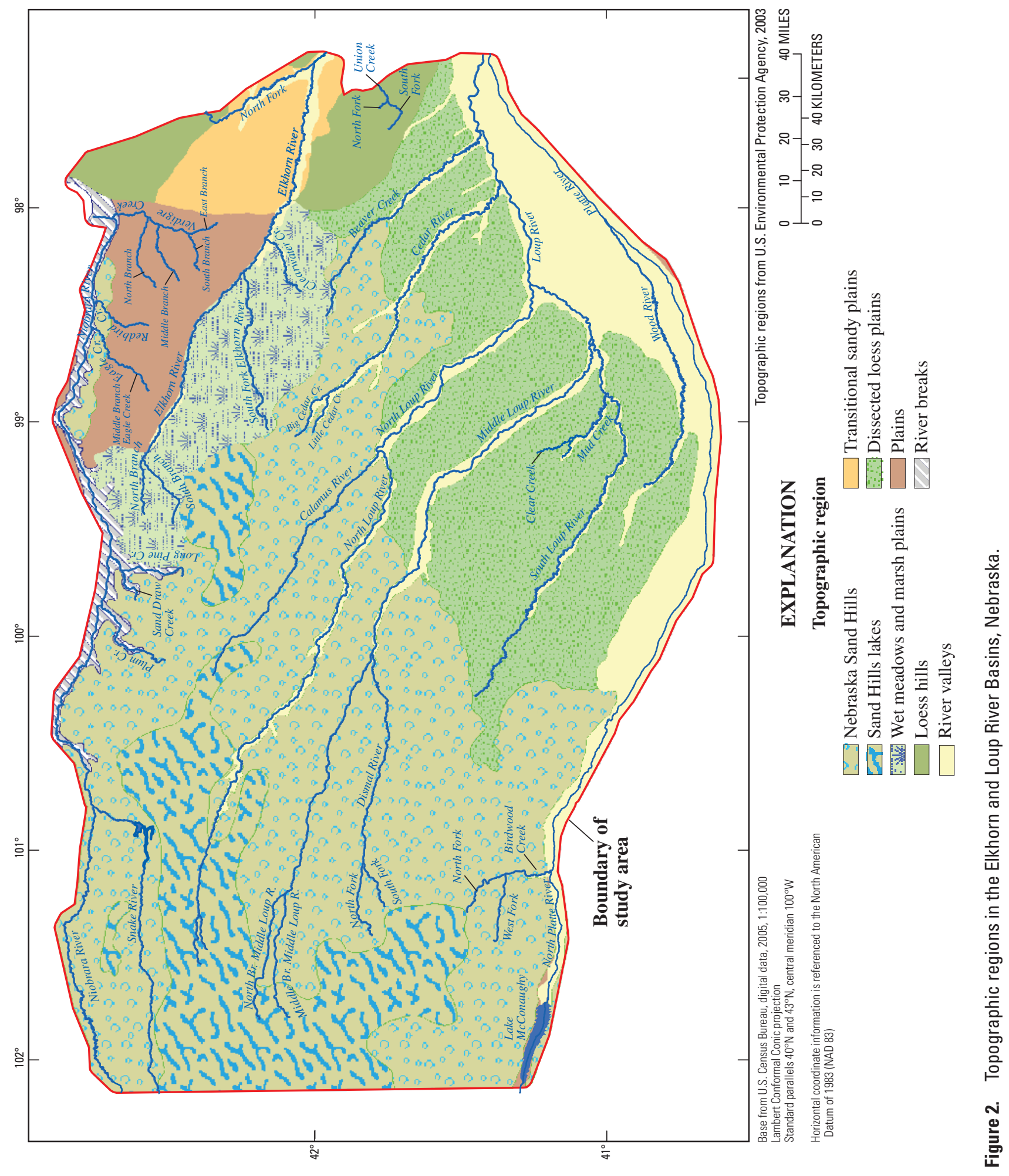


the North Loup River, Middle Loup River, and Cedar River) that originate in or at the boundary of the Sand Hills. Tributaries to the Loup River flow from northwest to southeast draining the Sand Hills and dissected loess plains. The Loup River flows either east or east-northeast through the large river valley region shared with the Platte River to the south.

\section{Water Use and Management}

Base flow is the primary component of streamflow in the Elkhorn and Loup River Basins. Based on ongoing surfacewater modeling work for the ELM area (Kellan Strauch, U.S. Geological Survey, oral commun., 2007) approximately 66 percent of the annual flow in the Elkhorn River is derived from ground-water discharge, whereas about 87 percent of the Loup River total annual flow is derived from ground-water discharge. Szilagyi and others (2003) also reported that base flow composed a large part of total flow in this area, ranging from more than 90 percent of total flow in the central Sand Hills to at least 50 percent in the rest of the ELM area, though values were not reported for specific streams.

Agriculture is vital to the livelihood of the communities within the ELM area, and irrigation is common because of large rates of evaporation and small rates of precipitation (fig. 3). In 2005, there were more than 2.8 million acres of irrigated agriculture within the ELM area (Patti Dappen, CALMIT, University of Nebraska-Lincoln, written commun., 2006). Surface water was used to irrigate more than 488,000 acres (Rick Vollertsen, Nebraska Department of Natural Resources, written commun., 2005; Allan Schmidt, Middle Loup Public Power and Irrigation District, written commun., 2006; Mel Brozek, Sargent Irrigation District, written commun., 2006; Jack Wergen, Bureau of Reclamation, written commun., 2006; Darwin Lee, Farwell Irrigation District, written commun., 2006; William Peck, U.S. Bureau of Reclamation, written commun., 2006; Ron Wolfe, Twin Loups Irrigation District, written commun., 2006); ground water was used to irrigate the remaining 2.3 million acres. Most surface-water irrigation takes place in the Loup River Basin, whereas no large irrigation diversions occur in the Elkhorn River Basin.

According to the Nebraska Natural Resources Commission (1998), total annual ground-water use in 1995 was 634,000 acre-feet (acre-ft) and 830,000 acre-ft in the Elkhorn and Loup River Basins, respectively. Ground-water pumpage (hereinafter referred to as pumpage) for agricultural land irrigation was 86 percent of total pumpage in the Elkhorn River Basin and 94 percent of total pumpage in the Loup River Basin. Recent drought (2000-06; National Climatic Data Center, 2006) has amplified concerns about long-term water-use sustainability in the Elkhorn and Loup Rivers, sustainability of the ground-water resources, interaction of surface and ground water, and the effect of pumpage on base flow.

In Nebraska, the responsibility for administration of ground-water and surface-water quantity laws is assigned to two separate governmental entities. Ground water primarily is managed by 23 NRDs (Neb. Rev. Stat. 2-3213 and
2-3229, Reissue 1997). NRDs are regional government entities whose boundaries are based generally on major surfacewater divides, though multiple NRDs exist within most major river basins. Surface water is managed by a state entity, the Nebraska Department of Natural Resources (NDNR). Doctrines governing ground-water and surface-water management differ as well. Ground water is governed by correlative rights, "share and share alike," whereas surface water is governed by the prior appropriations doctrine, "first in time, first in right."

In an effort to proactively resolve potential conflicts that may result between ground-water and surface-water users, state legislation was enacted in 2004 to ensure that long-term supplies of ground water and surface water are in balance with long-term demands. As part of this proactive approach, the NDNR is charged with conducting an annual evaluation of each river basin within the state, including the Elkhorn and Loup River Basins. This evaluation includes an assessment of the long-term effects of ground-water use on surface-water flows in areas where the aquifer is hydrologically connected to the stream. NDNR defines hydrologically connected areas as those areas within which pumping of a well for 50 years will deplete base flow by at least 10 percent of the pumped volume (Nebraska Department of Natural Resources, 2007).

If the results of the NDNR's analysis indicate that long-term mean streamflows are insufficient to meet longterm demands in a basin based on current ground-water and surface-water use, that basin is declared fully appropriated. This designation results in a moratorium being placed on new wells, new surface-water appropriations, and expansion of irrigated acres. In addition, the NDNR and the NRDs within the hydrologically connected areas determined to be fully appropriated must jointly develop an integrated management plan (IMP; Nebraska Department of Natural Resources, 2007). The primary objective of an IMP is to achieve a sustainable balance of water demands and water supplies of the surface- and ground-water system in the short and long term. The results of phase one of the ELM project, documented herein, could be used to assist the NDNR in conducting its annual evaluation.

\section{Hydrogeology}

Quaternary-age wind-deposited loess and fine-grained sand, alluvial silt, sand, and gravel, and Tertiary-age silts, sands, and gravels of the Ogallala Group (Condra and Reed, 1943) constitute the important geologic deposits forming the water-table aquifer in the ELM area. The Ogallala Group overlies silts of the Tertiary-age Arikaree Group across the western one-half of the ELM area, and otherwise generally overlies poorly permeable Cretaceous-age shale and limestone (Conservation and Survey Division, 1998). The base of the aquifer slopes gently to the east at about 8 feet per mile (ft/mi), and contains fairly wide paleo-valleys that also predominantly drain eastward (fig. 4). The Quaternary- and Tertiary-age geologic units in the area generally are unconsolidated and are simulated as one hydrostratigraphic unit (and one simulation layer) because they function as one continuous, connected, 


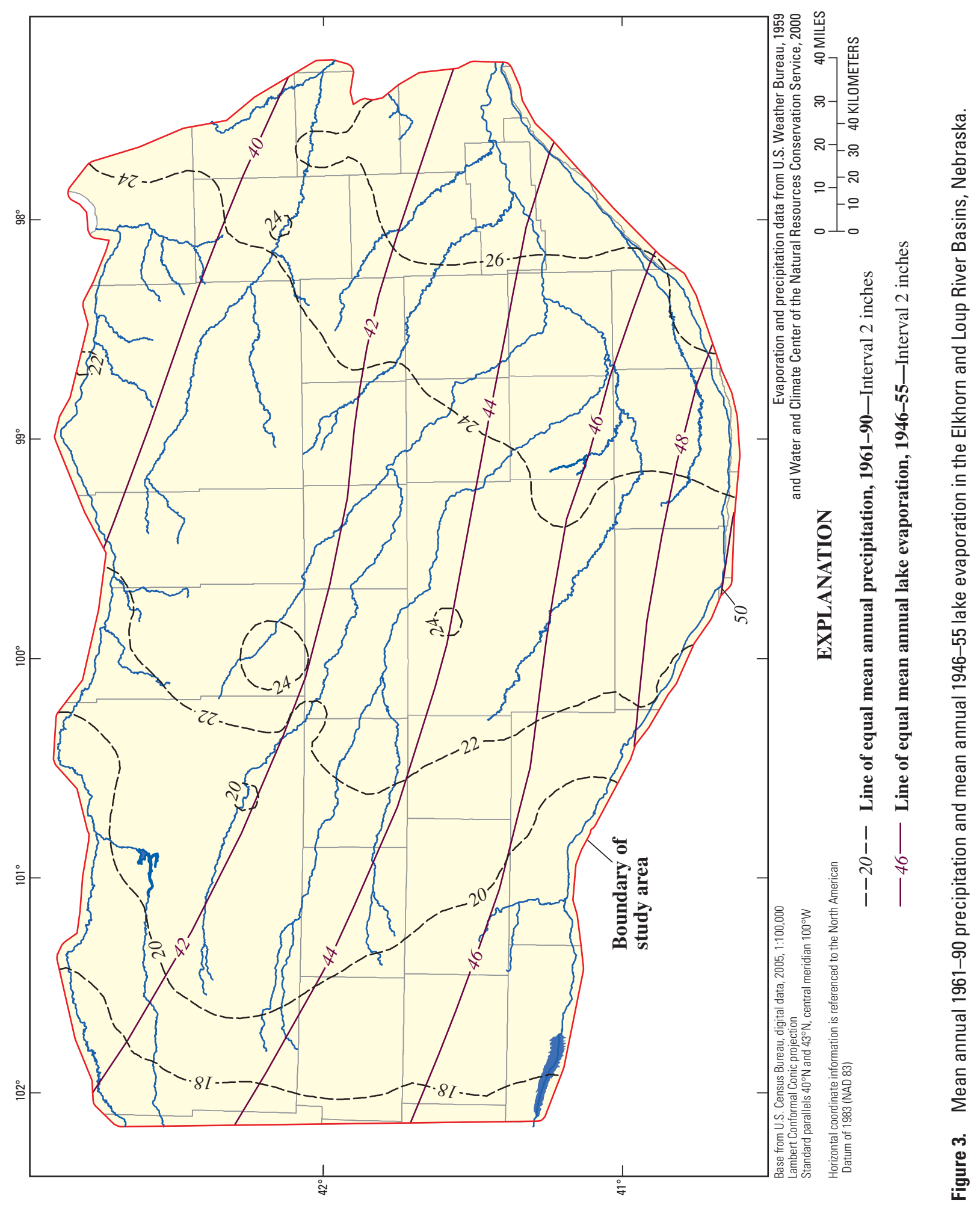




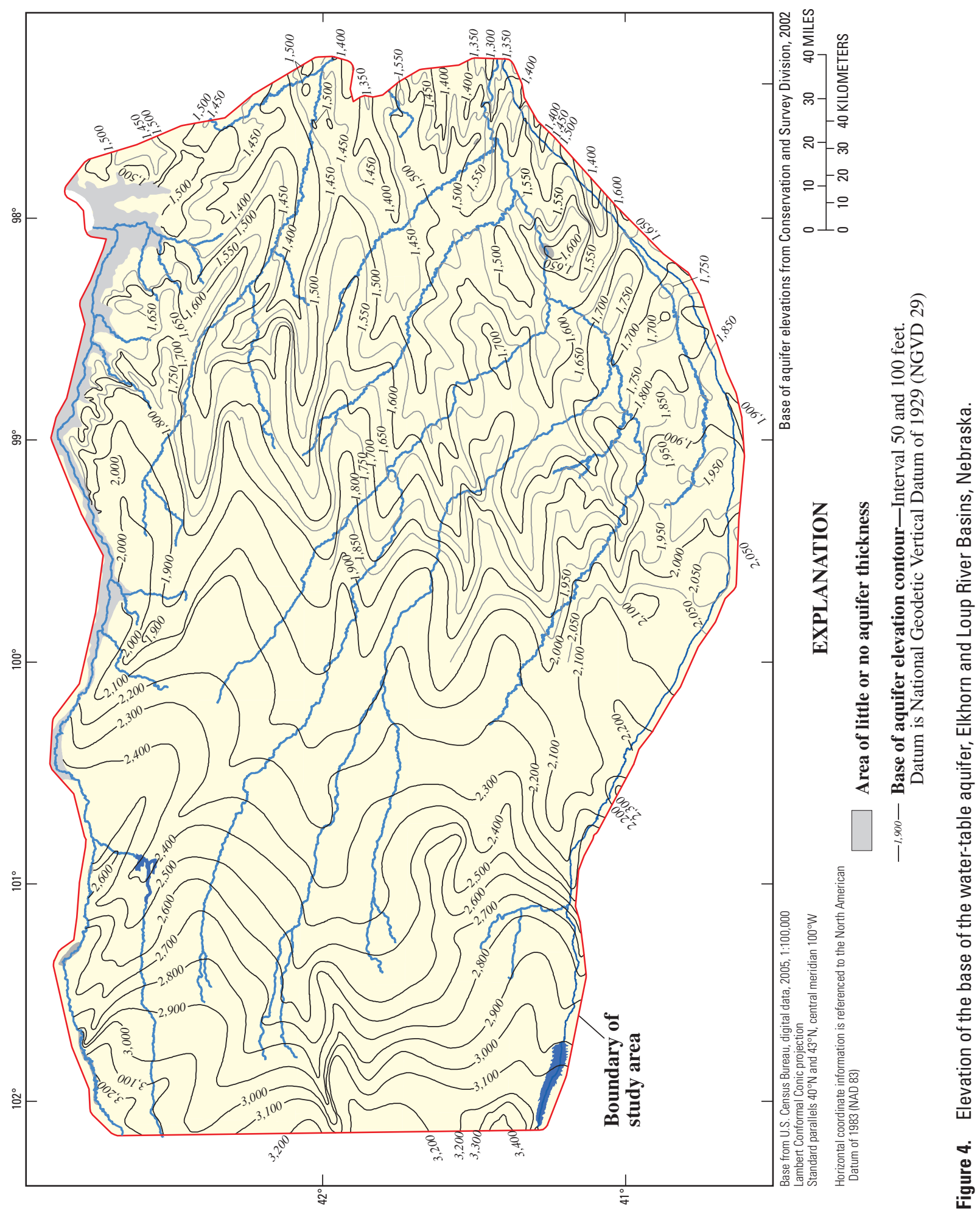


water-table aquifer on the regional scale. However, they are distinct geologically, both in terms of their depositional characteristics and hydrogeologic properties, which control how water locally flows through them.

Quaternary-age deposits are composed of wind-deposited silts or fine-grained sands (usually referred to as loess), or alluvial silt, sand, and gravel. Wind-deposited sands of the Nebraska Sand Hills overlie about 60 percent of the study area but mostly are above the regional water table, as are Quaternary-age loess deposits. Quaternary-age deposits have sufficient saturated thickness to be developed as a source of ground water in most of the ELM area, and can be as much as 700 feet (ft) thick but more commonly are found to be 150 to $200 \mathrm{ft}$ thick, with an average thickness of $144 \mathrm{ft}$ (Conservation and Survey Division, 2006). The Quaternary-age deposits usually are the coarsest deposits found in the study area and can support sustained pumping rates in excess of 1,000 gallons per minute (gal/min) (Nebraska Department of Natural Resources, 2005a). The only part of the ELM area where the Quaternary-age deposits generally are absent is near the Niobrara River (fig. 5), where Cretaceous-age deposits outcrop near land surface.

Ogallala Group deposits are present in most of the study area and are composed of clays, silts, sands, gravels, and poorly consolidated sandstone and siltstone. Ogallala Group deposits are absent where they have been eroded away near the Niobrara River along the northern study area boundary, near the eastern boundary of the study area, and along the Platte River in the southeast part of the study area. Ogallala Group deposits tend to be finer-grained than the Quarternaryage deposits, but frequently have much larger saturated thicknesses (fig. 5) (Conservation and Survey Division, 2005b), so yields of ground water to wells generally are sufficient for agricultural irrigation. Maximum Ogallala Group thicknesses described in test holes in the ELM area were around $700 \mathrm{ft}$, with an average thickness of about $170 \mathrm{ft}$ (Conservation and Survey Division, 2006); however, many of these test holes were not drilled all the way to the base of the Ogallala Group. Furthermore, the parts of the ELM area where the Ogallala Group deposits tend to be thickest actually contain the fewest number of test holes; therefore, the average thickness in test holes probably is not representative of the true average thickness in the study area.

Ground water in the ELM area generally flows from west to east with an average water-table slope of about $10 \mathrm{ft} / \mathrm{mi}$ (fig. 6) (Conservation and Survey Division, 2003). The water-table gradient tends to be larger in the Sand Hills, averaging $14 \mathrm{ft} / \mathrm{mi}$, and is less in the rest of the area, averaging 8 to $9 \mathrm{ft} / \mathrm{mi}$. Locally, such as near the Niobrara River, watertable gradients can be in excess of $10 \mathrm{ft} / \mathrm{mi}$, and range from 20 to $80 \mathrm{ft} / \mathrm{mi}$ as ground water moves from an upper, gently eastward-sloping plateau toward deeply incised valleys of the Niobrara River and its tributaries.

\section{Ground-Water Flow Simulation}

\section{Conceptual Flow Model}

A conceptual flow model is a narrative and schematic description of a ground-water flow system, and construction of a conceptual flow model is an important step in the process of building a ground-water flow model. In simple terms, the conceptual flow model describes how the ground-water flow system of an area is believed to behave; therefore, a conceptual model will contain information believed to be important to the occurrence and movement of ground water. The two most important components of a conceptual flow model are the boundaries and the water budget. The boundaries represent different parts of the flow system and how they interact with the ground water, and the water budget describes how much of the total water in the flow system is accounted for by each of the boundaries. Components of a conceptual flow model will vary depending on the system in question and study objectives.

Boundaries are critical to proper model design (Anderson and Woessner, 1992). A boundary is a physical feature that has an effect on the simulated flow system that can be measured or estimated, and thus be represented in the simulation (Reilly, 2001). Boundaries are both internal and external; internal boundaries are features 'inside' the simulation domain, such as a representation of streams or evapotranspiration areas, and external boundaries are those at the lateral or vertical extent of the simulated domain. Time also is a boundary, because the conditions simulated may depend on the time period of interest; however, time is addressed in the "Numerical Model Construction" section of this report (see the Simulation Periods subsection) because it is a special kind of boundary.

For the ELM study, the lateral external boundaries of the simulation consisted of either a drain boundary or zero-flow boundary along the northern boundary, combined zero-flow boundaries or fixed water-level boundaries for the eastern and western boundaries, and a fixed water-level boundary for most of the southern boundary, except at the western end where for some simulation periods it is a general-head boundary (fig. 7). The bottom (vertical) boundary of the simulation is the base of the water-table aquifer, and the upper vertical boundary is the water table. Areas that had been previously categorized as having no aquifer present or having a very thin aquifer (Conservation and Survey Division, 2002) were not included in the simulation (fig. 7).

Because the boundaries and their function are a major part of the conceptual flow model, each type of boundary is described in greater detail in the following paragraphs, grouped by boundary type. The specific implementation of these boundaries into the ground-water flow simulation are described in the "Numerical Model Construction" section of this report. 


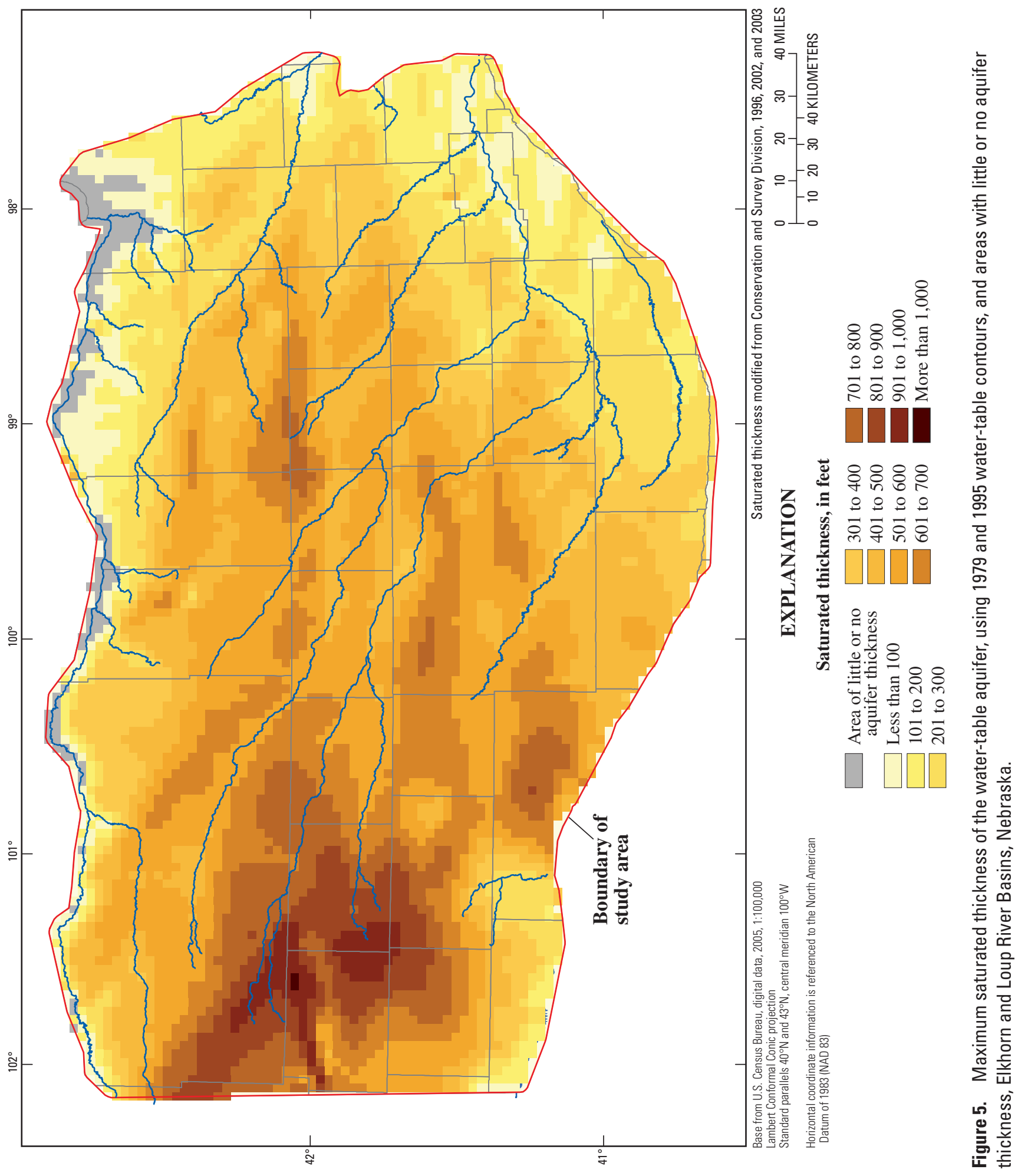




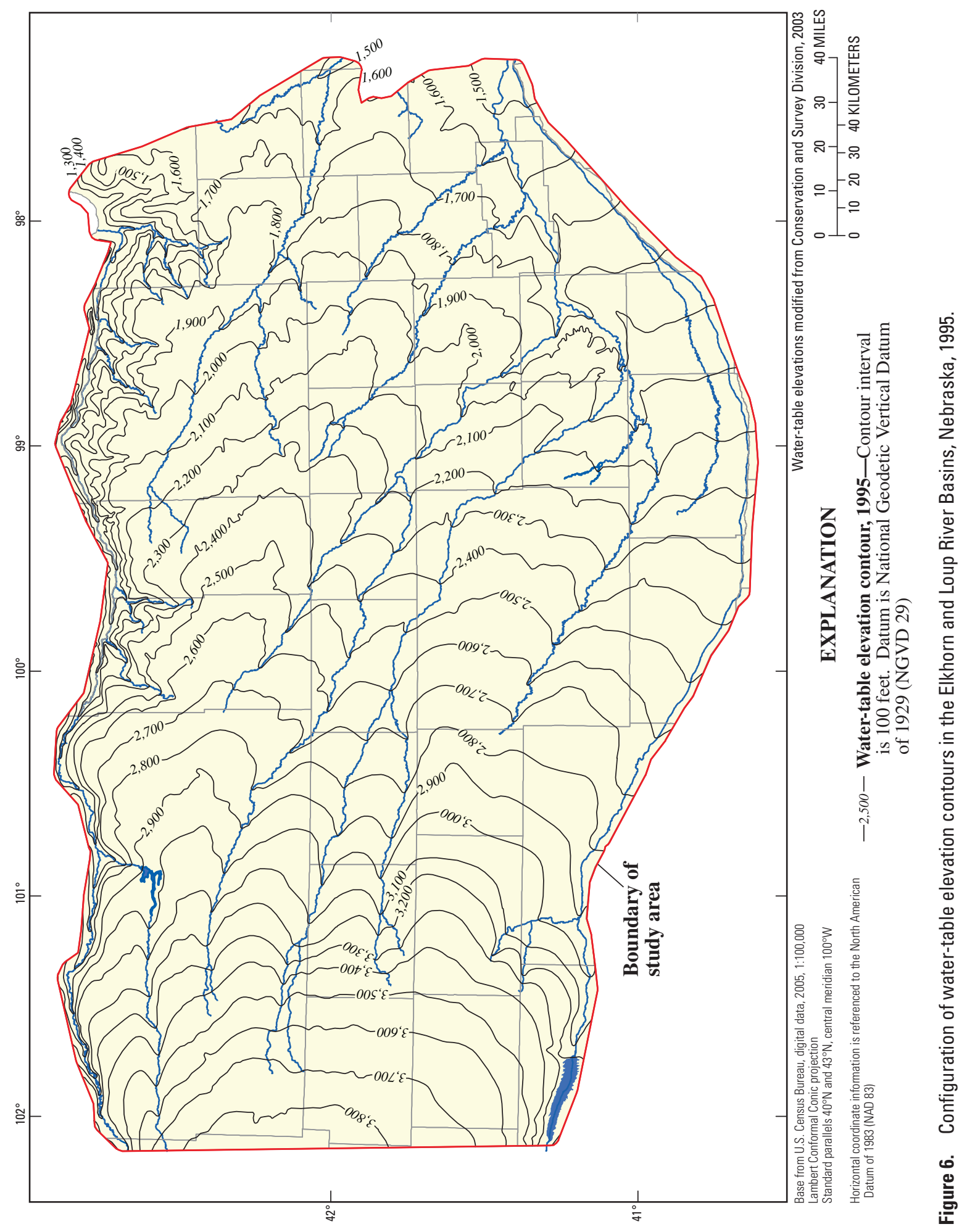


A zero-flow boundary represents a hydrologic condition whereby no water flows across the boundary in any direction. A zero-flow boundary was used for several parts of the external boundary, as well as for the bottom boundary at the base of the aquifer. A zero-flow boundary was used for some reaches of the northern external boundary because the watertable aquifer thins from south to north and in some areas is absent near the Niobrara River valley (fig. 7). In some areas of the valley, the water-table aquifer is thin or absent, and the Niobrara River generally flows across poorly permeable Cretaceous-aged bedrock (Conservation and Survey Division, 1996a; 1996b). A zero-flow boundary also was used for parts of the eastern and western simulation boundaries where flow was dominantly parallel to the external boundary, thus no flow crosses the external boundary. Flow directions near these external boundaries were interpreted from a 1995 water-table contour map (Conservation and Survey Division, 2003). A zero-flow boundary also was used for the northern part of the eastern boundary, where the water-table aquifer is extremely thin and has a low hydraulic conductivity, indicating that flow is negligible for the regional system (Conservation and Survey Division, 2005b).

Fixed water-level boundaries were used for the central part of the eastern and western external simulation boundaries. In these areas, cross-boundary ground-water flow is likely to occur based on interpretations from 1995 water-table contours (Conservation and Survey Division, 2003). A fixed water-level boundary means that the initial water levels assigned to that boundary always are maintained. As water flows from a fixed water-level boundary downgradient, or as upgradient water flows to fixed water-level boundaries, water is either added to or removed from the simulated flow system to maintain the water level at the assigned elevation. Fixed water-level boundaries potentially could either add or remove large amounts of ground water from the simulated flow system because the assigned water level always is maintained. Therefore, it is common practice (Anderson and Woessner, 1992) to review the simulation outputs to verify that the amounts added or removed by a fixed-water level boundary are consistent with the gradient and transmissivity of the water-table aquifer in those areas. A fixed water-level boundary also was used for the southern external simulation boundary to represent ground-water discharge to the Platte River, or in some cases, water being lost by the Platte River to the ground-water system. In the long-term, water-levels in this area near the Platte River are stable; therefore, use of a fixed water-level boundary seemed appropriate and unlikely to affect simulation results in the interior of the simulation.

A drain boundary was used for some of the northern external simulation boundary and represents parts of the Niobrara River that may have sufficient saturated thickness in the river valley alluvium to allow interaction between the river and the ground-water system. A drain boundary removes water from a simulated ground-water flow system based on the difference between elevations assigned to the drain boundary and the simulated ground-water elevation, and based on physical properties describing the geometry and hydraulic conductivity of a hypothetical bed layer (McDonald and Harbaugh, 1988).

This hypothetical bed layer may not always exist in nature, but if the actual streambed contained finer-grained sediments than those in the water-table aquifer, the conductance assigned to that drain boundary could be reduced to decrease the simulated flow from ground water to the drain boundary. Drain boundaries were used to simulate stream-aquifer interaction in the Niobrara River Basin (except the Snake River) because large gradients in simulated water levels in this area caused stability issues (the computer model could not iterate to a numerical solution) when stream boundaries were used to simulate stream-aquifer interaction. Niobrara River tributaries simulated with drain boundaries include Eagle Creek, Long Pine Creek, Plum Creek, Redbird Creek, Sand Draw Creek, and Verdigre Creek (fig. 7). These streams predominantly are gaining streams in nature, that is, most of their flow arises from ground-water discharge to the stream (base flow) (Kellan Strauch, U.S. Geological Survey, written commun., 2008); therefore, it is appropriate to simulate these streams using a drain boundary.

Stream boundaries were used to simulate most of the streams in the ELM area. Similar to drain boundaries, stream boundaries can remove water from the simulated groundwater flow system. The amount of water removed is controlled by the conductance of the hypothetical streambed layer and relative elevations of the stream stage and the simulated ground-water elevation (Prudic, 1989). However, stream boundaries also route the water removed from the water-table aquifer downstream based on Manning's equation (Prudic, 1989) and inputs describing the gradient and width of the channel, which is assumed to be rectangular. The simulated stream may contribute the routed water back to the water-table aquifer when the simulated ground-water elevation under the streambed is less than the simulated stream stage. The amount of loss is controlled by the difference in the elevations and conductance specified for the hypothetical streambed layer. Stream boundaries were used to simulate perennial reaches of Birdwood Creek, Cedar Creek, the Cedar River, the Calamus River, Clearwater Creek, the Dismal River, the Elkhorn River, the Loup River, the Middle Loup River, Mud Creek, the North Fork of the Elkhorn River, the North Loup River, the Snake River, the South Loup River, the South Fork of the Elkhorn River, Union Creek, and the Wood River (fig. 7). The Snake River was simulated using a stream boundary even though drain boundaries were used to simulate the rest of the streams in the Niobrara River Basin because water-level gradients in the Snake River area were smaller than they were in the rest of the Niobrara River Basin, and the water-table aquifer was thicker. Stream reaches not shown in figure 7 were not included in the simulation.

A general-head boundary was used to simulate Lake McConaughy (fig. 7) for 1940 through 2005. General-head boundaries are similar to fixed-water level boundaries, except that the interaction of the boundary with the simulated groundwater system is controlled by a conductance term, similar to 


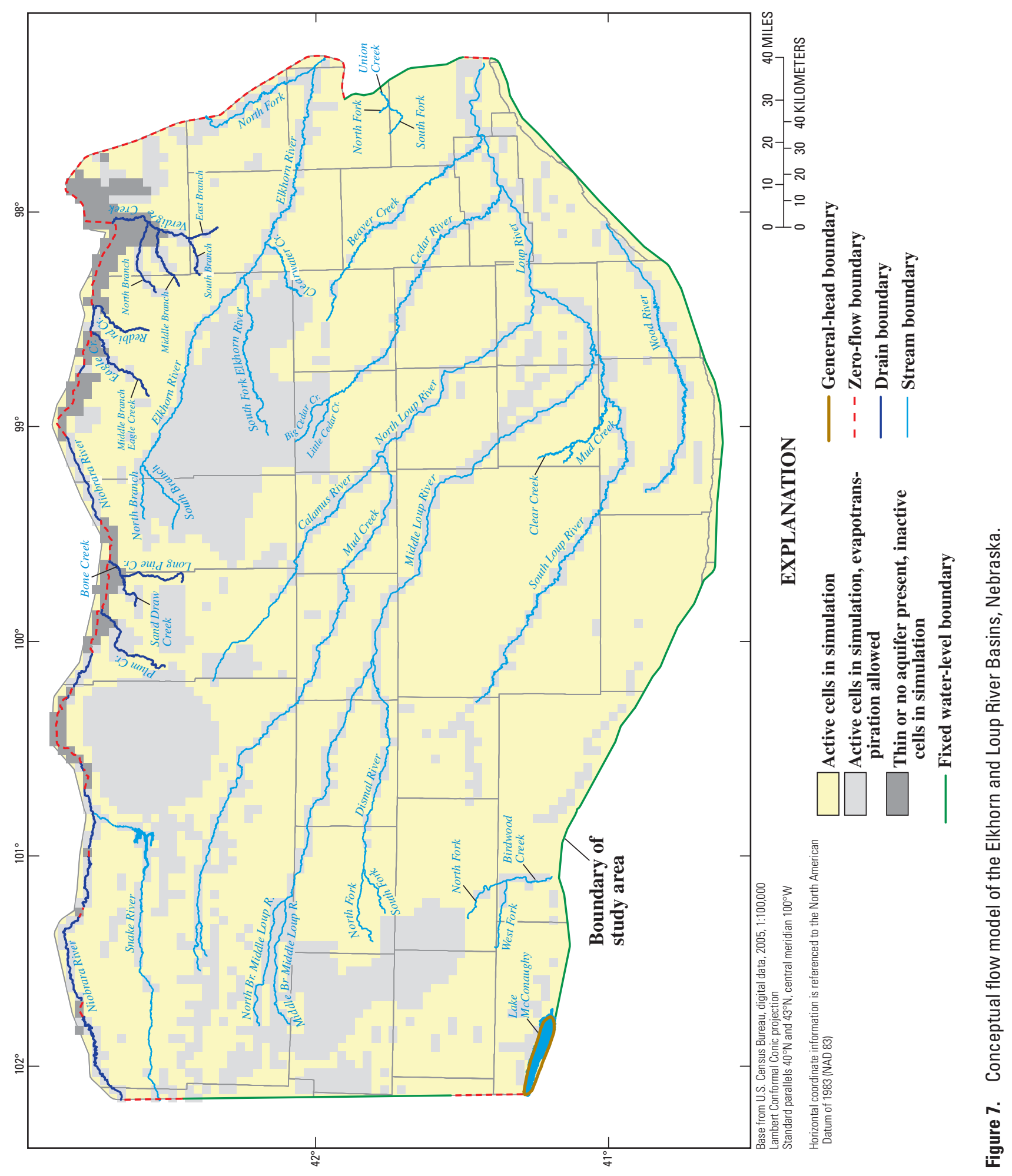


the term used for drain and stream boundaries (McDonald and Harbaugh, 1988). General-head boundaries commonly are used to simulate lakes, although, as with fixed-water level boundaries, care must be taken to ensure that the amount of water exchanged between the general-head boundary and the ground-water system is realistic, as must be done for all assigned boundaries (Reilly and Harbaugh, 2004).

Simulated evapotranspiration was used to represent the sum of transpiration of ground water by plants and evaporation of ground water near or at land surface. In some areas, evapotranspiration can remove large amounts of ground water at or near land surface; therefore, evapotranspiration was included in the ground-water flow simulation. The rate at which evapotranspiration can occur is controlled by the assigned maximum evapotranspiration rate, the relative elevation of the simulated ground-water levels and the assigned evapotranspiration elevation, and the input extinction depth, which is the depth below the evapotranspiration elevation at which evapotranspiration does not occur. Evapotranspiration was specified to occur near major streams and in areas mapped as wetlands or riparian areas (U.S. Fish and Wildlife Service, 2005), and the maximum evapotranspiration rate was set to zero in all other areas of the simulation. Simulated evapotranspiration for this report is specific to ground water and should not be confused with evapotranspiration of soil moisture or other sources of water not in connection with the regional water-table aquifer.

Recharge is the amount of water that infiltrates land surface and moves downward below the root zone and eventually crosses the regional water table; thus the term "recharge" is always used in this report to mean, more specifically, recharge to ground water. Recharge from precipitation was simulated as occurring nearly everywhere in the ELM, except on bluffs and escarpments, using the conceptual approach that recharge would be larger on coarser-grained soils than on finer-grained soils, and that it would be larger on level areas than on more steeply sloping areas. Recharge was not simulated on bluffs and escarpments because precipitation that falls on bluffs and escarpments likely becomes runoff instead of recharge.

The hydrologic budget consists of inflow and outflow components. The inflow budget components in the ELM were (1) ground water that had been released from storage (resulting in water-level declines), (2) ground-water flow into the study area from the west and from the Platte River, (3) seepage from Lake McConaughy, (4) recharge from canal and lateral seepage (alternately referred to as canal-seepage recharge), (5) additional recharge applied to irrigated cropland areas, (6) additional recharge applied to nonirrigated cropland areas, (7) additional recharge applied to Hall and Buffalo Counties, (8) recharge from precipitation, and (9) inflows of base flow from stream boundaries. The outflow budget components in the ELM were (1) ground-water outflow to storage (resulting in water-level rises), (2) ground-water flow out of the study area to the east and to the Platte River, (3) seepage to Lake McConaughy, (4) outflows to stream base flow, (5) outflows to stream base flow for streams represented by drain boundaries, (6) evapotranspiration, (7) pumpage for irrigation, and (8) pumpage for municipal use.

The relative magnitude of the conceptual flow model budget was estimated. The largest inflow component of the conceptual flow model budget was recharge from precipitation, and other inflow components were expected to be a small part of the overall budget. Stream base flow was expected to be the largest outflow, followed by evapotranspiration. Other budget components were expected to be a small part of the overall budget. Quantitative volumetric flow rates for each budget component were not available to compare to the conceptual flow model budget. However, our qualitative assessment of relative flow rates is our best representation of the budget given the data available and our current (2007) understanding of the ground-water flow system.

\section{Numerical Model Construction}

MODFLOW (McDonald and Harbaugh, 1988) and its revisions (Harbaugh and others, 2000; Harbaugh, 2005) are the most commonly used finite-difference ground-water flow model software. Simulations were built for this study using MODFLOW-2000, through the GMS 6.0 pre- and post-processor (Environmental Modeling Systems, Inc., 2007). The study area was simulated using a uniformly spaced grid consisting of 81 rows and 124 columns of 2 mi by 2 mi cells, and areas where the aquifer was thin or absent (Conservation and Survey Division, 2002) were not included in the simulation. The single vertical layer was simulated as an unconfined aquifer. Ground-water flow equations were solved using a geometric multigrid solver (GMG) (Wilson and Naff, 2004).

\section{Assumptions}

Whereas using MODFLOW and simulation of groundwater flow systems through finite-difference solution techniques implies many assumptions (McDonald and Harbaugh, 1988), some primary assumptions important for ELM study objectives are presented here.

1. Regionally, flow predominantly is horizontal and the water-table aquifer is unconfined. There is neither evidence for vertical ground-water flow or confining conditions in most of the simulation area nor regionally important confining units that might prevent full connection between deposits composing the water-table aquifer. Therefore, the system can be appropriately simulated with a single vertical simulation layer.

2. Water flows through the water-table aquifer according to Darcian flow principles. That is, the water in the watertable aquifer is incompressible, the water-table aquifer is homogeneous and isotropic, and behaves as if it is infinite in areal extent. Flow is laminar rather than turbulent. 
3. The water-table aquifer can be appropriately simulated using grid cells that are 2 mi by 2 mi in size, and watertable aquifer properties are uniform within the area of each grid cell. It is recognized that some system properties change over distances less than $2 \mathrm{mi}$, but this assumption is appropriate for simulations meant to be used for regional management scenarios. In addition, using a relatively large cell size allowed simulations to run more quickly; shorter execution times improved efficiency of the simulation effort, to more effectively meet study objectives.

4. Sources and sinks of water that have an important effect on the ground-water flow system, such as streams, pumpage, and recharge, can be appropriately simulated using grid cells that are 2 mi by 2 mi in size. It is recognized that streams in the area actually occupy areas much less than 2 mi wide, but as with assumption 3, it is acceptable for simulations meant to be used for regional management scenarios. This assumption also means that this simulation cannot be used to analyze features that are within $1 \mathrm{mi}$ of streams, because when aggregated to $2 \mathrm{mi}$ cells, those features may be in the same grid cell as the stream. In some situations, the valleys of small streams may not be represented in the inputs to the much larger grid cells, and if the stream is controlled in nature entirely by processes that occur within the valley, the simulation may not correctly represent that stream. Lastly, land-use data in part control the pumpage and recharge used in the simulations, and land-use data were available at a finer resolution than the selected grid size, but any errors caused by aggregation of these data to $2 \mathrm{mi}$ by $2 \mathrm{mi}$ grid cells would be negligible in these simulation results. The selection of the grid cell size for building a simulation for this area was guided by the desire for simplicity, because simplicity enhances model transparency and helps keep model execution time short; short execution times facilitate completion of the numerous simulations needed to characterize and understand system behavior, and test models against data (Hill, 2006).

5. The ground-water flow system before major anthropogenic effects was in long-term equilibrium, which can be approximated using a steady-state simulation. As no anthropogenic effects would have been present in the system at that time, and ground-water levels would represent the integration of climate effects that occurred during the previous decades or centuries, this assumption is thought to be appropriate.

6. Water that leaks from canals and eventually reaches the water table can be appropriately simulated as recharge. Whereas this assumption may not be true for short periods, such as days or weeks, or for small areas, it is appropriate for a simulation spanning years and for regional ground-water flow systems.

\section{Simulation Periods}

As mentioned in the "Conceptual Flow Model" section of this report, time is a special simulation boundary that must be carefully considered when constructing a simulation. To represent time, ground-water systems can be simulated either under 'steady-state' or 'transient' conditions. A steady-state simulation represents an instantaneous snapshot of a groundwater system in equilibrium with all inflows and outflows. The simulated steady-state water level for a particular grid cell is independent of the assigned starting water level and does not change with time, rather it depends only on the properties assigned to the cell, the interaction with surrounding cells, and the sources and sinks affecting that cell, such as recharge or evapotranspiration.

In contrast, a transient simulation represents a specified period of elapsed time, such as a number of days, weeks, months, or years, broken up into "time steps" for each of which the solution is calculated. Generally, transient simulations are used to simulate some aspect of the system that is time-dependent, such as development of pumpage for irrigation that may begin and end in different places at different times; a transient simulation also might be used to simulate the effects of canal-seepage recharge as a new canal system begins operations or changes operations. Another difference from steady-state simulations is that a transient simulation calculates only the changes from the initial water levels because of the simulation stresses, so erroneous starting water levels can strongly affect simulation results (Reilly and Harbaugh, 2004). For some simulations, especially those of large regions, the amount of time for which non-equilibrium starting water levels could affect the simulation could be hundreds or even thousands of years.

For the ELM study, the primary goal was to simulate recent conditions, perhaps of the last few decades, accurately enough that the simulation could be used as a tool to evaluate system behavior during those last few decades, as well as to evaluate system response under assumed future conditions. The first surface-water diversions for irrigation began in the ELM area around 1895; pumpage for irrigation was becoming increasingly more common near the Platte River in the 1940s and expanded considerably during the 1950s, 1970s, and continued until current times (Nebraska Department of Natural Resources, 2005a). Water levels measured during these times were in a state of flux and not reliable to use as starting water levels. Therefore, a pre-1895 simulation was constructed to represent the system in long-term equilibrium before the onset of anthropogenic effects. Water levels from the pre-1895 simulation could then be used as reliable starting water levels for the pre-1940 transient simulation, and simulated 1940 water levels could be used as reliable starting water levels for the 1940 through 2005 simulation. Because major changes in land-use practices occurred from 1895 to 1940 and from 1940 through 2005, these were selected as critical periods for which to build separate transient simulations. 
Following the pre-1895 steady-state simulation, transient simulations of 1895 to 1940 and 1940 through 2005 represented the effects of new activities that were changing the system. The simulation of 1895 to 1940 included the processes active during the long-term equilibrium of the steady-state simulation, but with added recharge of water that leaked from canals during this time. This simulation included two stress periods and 500 time steps, so each time step represented approximately 32.9 days. The simulation of 1940 through 2005 included pumpage for irrigation, canal-seepage recharge, additional recharge from precipitation on nonirrigated and irrigated cropland areas, and additional recharge applied to Hall and Buffalo Counties. The 1940 through 2005 period was simulated using annual (66) stress periods, each with 20 time steps of 18.3 days. Shorter time steps were used for 1940 through 2005 because it was expected that with the extra stresses applied to the system to simulate pumpage for irrigation, shorter time steps would improve the accuracy of the solution.

\section{Pre-1940 Simulation}

\section{Simulation Inputs}

This section describes simulation inputs that were not adjusted as part of the calibration process, including the water levels at fixed water-level boundaries, base of the watertable aquifer, specific yield, specific storage, canal-seepage recharge, stream and drain boundary inputs other than conductance, and evapotranspiration inputs other than the maximum evapotranspiration rate. Inputs that were adjusted for the subsequent transient simulation are described under "Simulation Inputs" in the "1940 through 2005 Simulation" section of this report.

Fixed water levels for the southern boundary were assigned based on simulated 1895 water levels from simulations built for the Platte River Basin (Clint Carney, Nebraska Public Power District, written commun., 2007). For the other fixed water-level boundaries, water levels were assigned based on the 1979 and 1995 water-table contour maps (Conservation and Survey Division, 1996c, 2003).

The base of water-table aquifer (lower boundary of the simulation) was derived from an elevation contour map created by the Conservation and Survey Division (2002) and additional test-hole drilling logs made available by the University of Nebraska (Conservation and Survey Division, 2006). Highest elevations (about 3,500 ft) are in the west and generally decrease to the east (to about 1,200 ft; fig. 4).

Specific yield values, representing water obtained by draining the aquifer pores (Fetter, 1994), were interpolated from points and contour lines obtained from the Conservation and Survey Division (2005c). Interpolated values ranged from 0.01 to 0.3 with a mean of 0.14 . Smaller values were located in the northeast part of the study area in the Niobrara
River valley. Areas of larger specific yield were located in the southwest (Arthur, Grant, Hooker, and McPherson Counties; fig. 1) and the southeast (primarily Boone, Merrick, and Platte Counties). Specific storage reflects the amount of water that is obtained as an aquifer undergoes decompression when water is removed (Fetter, 1994); though typically this is ignored for a regional unconfined flow system because it is much smaller than the amount of water yielded through aquifer drainage. For this simulation specific storage was set to a constant value of $0.00001 \mathrm{ft}^{-1}$.

Recharge from leakage of the Cozad, Dawson, Elm Creek, Gothenburg, and Kearney canal systems (fig. 8) was simulated during the pre-1940 period (table 1) with MODFLOW's recharge (RCH) package. Cozad, Dawson, Gothenburg, and Kearney canal systems began operation around 1895. The Elm Creek canal system began operation in 1929. Because neither measurements of canal seepage nor volumes of water delivered to fields were available for these canal systems, recharge from canal and lateral seepage was estimated to be 43 percent of the yearly water diverted from the Platte River, minus any water returned back to the Platte River, based on previous work (Duane Woodward, Central Platte NRD, oral commun., 2002). Canal-seepage recharge does not include enhanced recharge that may occur because of overirrigation, that is, the application of surface water in excess of what the crops could use. Over-application could increase recharge or runoff from fields but was assumed to have minimal effect. Information describing over-application was not available. Recharge caused by leakage from each canal system was distributed evenly across the simulation grid cells within the extent of its delivery area.

Streambed elevations for streams simulated with MODFLOW's stream (STR) package were assigned from a digital elevation model (DEM) (Nebraska Department of Natural Resources, 1997) queried at regular intervals along each stream reach, and values were interpolated linearly between the assigned elevations in GMS 6.0 (Environmental Modeling Systems, Inc., 2007). Streambed width and elevation are used by the stream-routing package to compute streamflow volumes and stages (Prudic, 1989). Streambed width and elevation should not be confused with terms used related to conductance or stream leakage; readers desiring additional information regarding stream package terms are directed to Prudic (1989). The width of each stream reach was determined either from measurements made at stream-gaging stations or USGS 1:24,000-scale topographic maps. The stream bottom elevation partially controls the simulated interaction of the stream with the ground-water system; it was assigned to be $1 \mathrm{ft}$ below the streambed elevation throughout the simulation domain. For streams simulated as drain boundaries using MODFLOW's drain (DRN) package, drain elevations were assigned by querying a DEM (Nebraska Department of Natural Resources, 1997) at regular intervals along each drain reach, and values were interpolated linearly between the manually assigned elevations in GMS 6.0. 


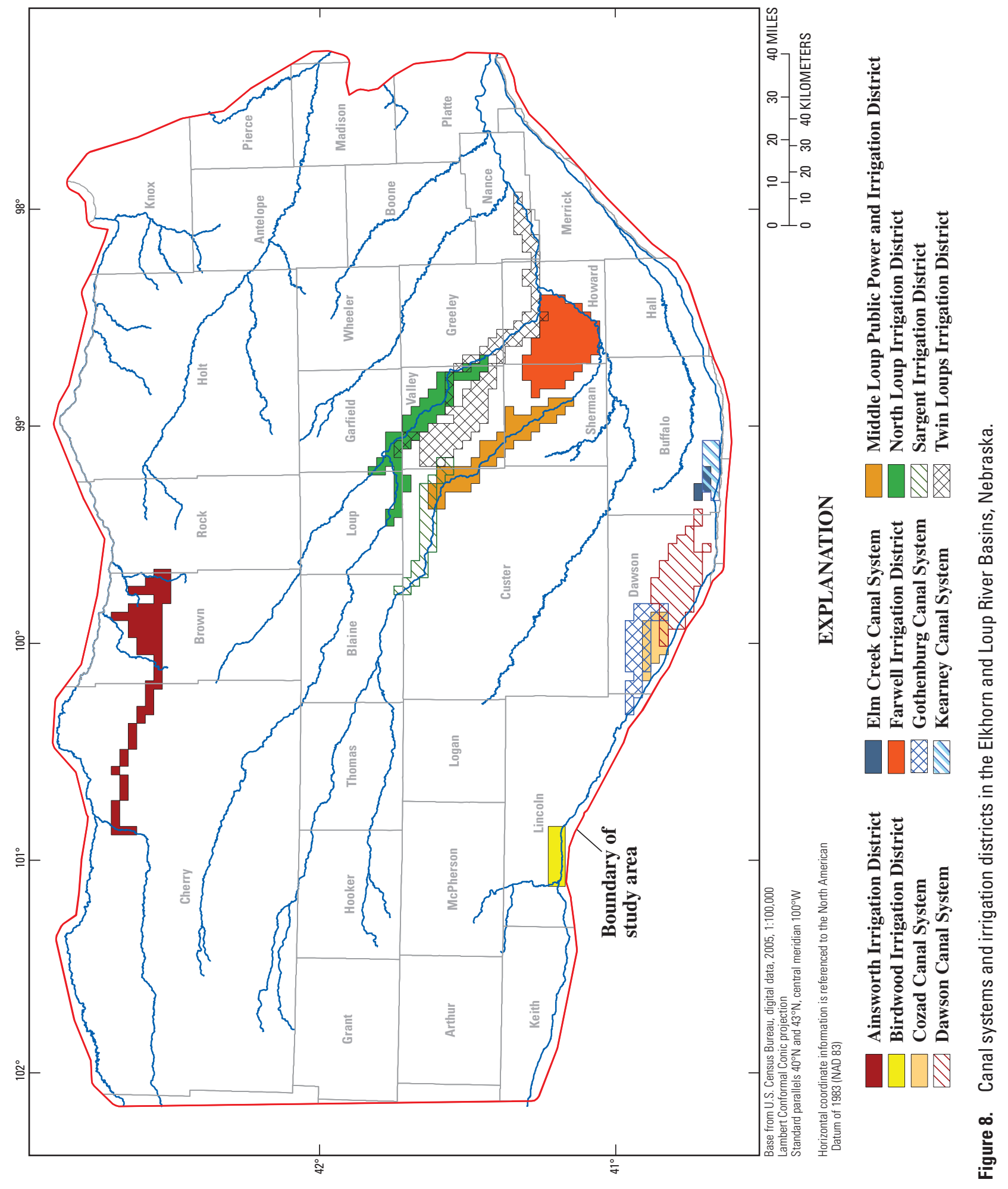


Table 1. Estimated recharge from canal and lateral seepage during the pre-1940 simulation, Elkhorn and Loup River Basins, Nebraska.

\begin{tabular}{lccc}
\hline Canal system & $\begin{array}{c}\text { First year of } \\
\text { operation }\end{array}$ & $\begin{array}{c}\text { Estimated annual } \\
\text { seepage, in cubic } \\
\text { feet }\end{array}$ & $\begin{array}{c}\text { Estimated } \\
\text { annual } \\
\text { seepage, in } \\
\text { acre-feet }\end{array}$ \\
\hline Cozad & 1895 & $506,777,047$ & 11,634 \\
Dawson & 1895 & $1,093,051,096$ & 25,093 \\
Gothenburg & 1895 & $1,508,221,462$ & 34,624 \\
Kearney & 1895 & $214,968,603$ & 4,935 \\
Elm Creek & 1929 & $134,382,602$ & 3,085 \\
\hline
\end{tabular}

Evapotranspiration was simulated using MODFLOW's evapotranspiration (ET) package. Evapotranspiration removes ground water at a specified maximum rate when the simulated water level is at or above a specified elevation, usually assigned as land-surface elevation. An extinction depth also is specified, and when the simulated water level is at or below this depth, evapotranspiration does not remove ground water from the simulation. Between the specified elevation and the extinction depth, the rate at which water is removed varies linearly between the maximum rate and zero (McDonald and Harbaugh, 1988). Extinction depth was set to a constant value of $5 \mathrm{ft}$. In nature, evapotranspiration may remove ground water more than $5 \mathrm{ft}$ deep, but it is assumed that most groundwater discharge to evapotranspiration occurs within the top $5 \mathrm{ft}$ and is minimal below that depth. The specified elevation for evapotranspiration was set to the 25th percentile of land-surface elevation in each grid cell as determined from a DEM having 30-m resolution (Nebraska Department of Natural Resources, 1997). The 25th percentile of land-surface elevations was used because evapotranspiration typically is confined to the lower elevations of a grid cell where ground water most likely is near the land surface.

\section{Calibration Targets}

Ground-water level measurements were obtained from the USGS National Water Information System (U.S. Geological Survey, 2005). Measurements generally were not widely made during the pre-1940 period. Therefore, observed groundwater levels used for calibrating this simulation were the earliest available measurements considered to have water levels unaffected by ground-water irrigation.

The first criteria applied to determine if a water-level measurement may have been affected by ground-water irrigation was whether or not the well was located on irrigated cropland. Initially, 934 wells within the study area were selected because they were not on parcels of land identified as irrigated in 2005. Subsequently, these 934 wells were filtered by removing all water levels that had been measured within $4 \mathrm{mi}$ of an active irrigation well to reduce potential effects of pumping. This resulted in 546 water-level measurements being used for calibration of the pre-1940 simulation (fig. 9).

The 546 water-level measurements used for calibration were collected between 1928 and 2002, with a mean collection year of 1959. The distribution of water-level measurements was fairly consistent across the study area (fig. 9), though the measurements were more widely distributed in the south. Most water-level data that had been collected in later decades, such as from 1980 to 2002, were from Arthur and McPherson Counties, which were still mostly undeveloped for agriculture in 2005 .

Estimated long-term base flow was determined using streamflow data recorded at 22 USGS streamflow-gaging stations (fig. 9) during the fall (October and November), using the entire period of record for each station. Fall discharge data were chosen because streamflows are less affected by diversions, riparian evapotranspiration, and runoff, and were therefore more likely to represent the base-flow component of streamflow. Methods used to estimate base-flow values have been described by Peterson and Carney (2002). A statistical or other detailed analysis of base-flow trends was beyond the scope of the study, but because the base-flow estimates were computed using the entire period of record, which in many cases includes several decades from about the 1930s to 2000s, the base-flow estimates are regarded as indicative of long-term base-flow conditions. Therefore, the approach to base-flow calibration was that if the 1940 simulated base flows were about the same as the "long-term" estimated base flows, the simulation was considered calibrated with respect to those base flows.

\section{Calibration Process}

In addition to the simulation inputs that were fixed during construction, some simulation inputs were adjusted through a trial-and-error approach to improve the match between the simulated and measured water levels, as well as the match between simulated and estimated long-term base flow. Model inputs that were adjusted during the calibration process included aquifer hydraulic conductivity, recharge from precipitation, stream-boundary conductance, drain-boundary conductance, and the maximum evapotranspiration rate.

Initial values of horizontal hydraulic conductivity $(H K)$ were assigned based on a conceptual distribution. This conceptual distribution was based on expected regional trends of hydraulic conductivity represented by drawing polygons to assign one value of hydraulic conductivity for each polygon, interpreted to be contiguous areas of similar lithology. The initial $H K$ values assigned to each polygon were from scientific literature (Fetter, 1994). The simplicity of this distribution enhanced convergence for the initial simulations. A second data set of $H K$ was later derived from transmissivity contour maps and points provided by Conservation and Survey Division (Conservation and Survey Division, 2005b; Rick Vollertsen, Nebraska Department of Natural Resources, written commun., 2005) and aquifer saturated thickness in 1979 and 


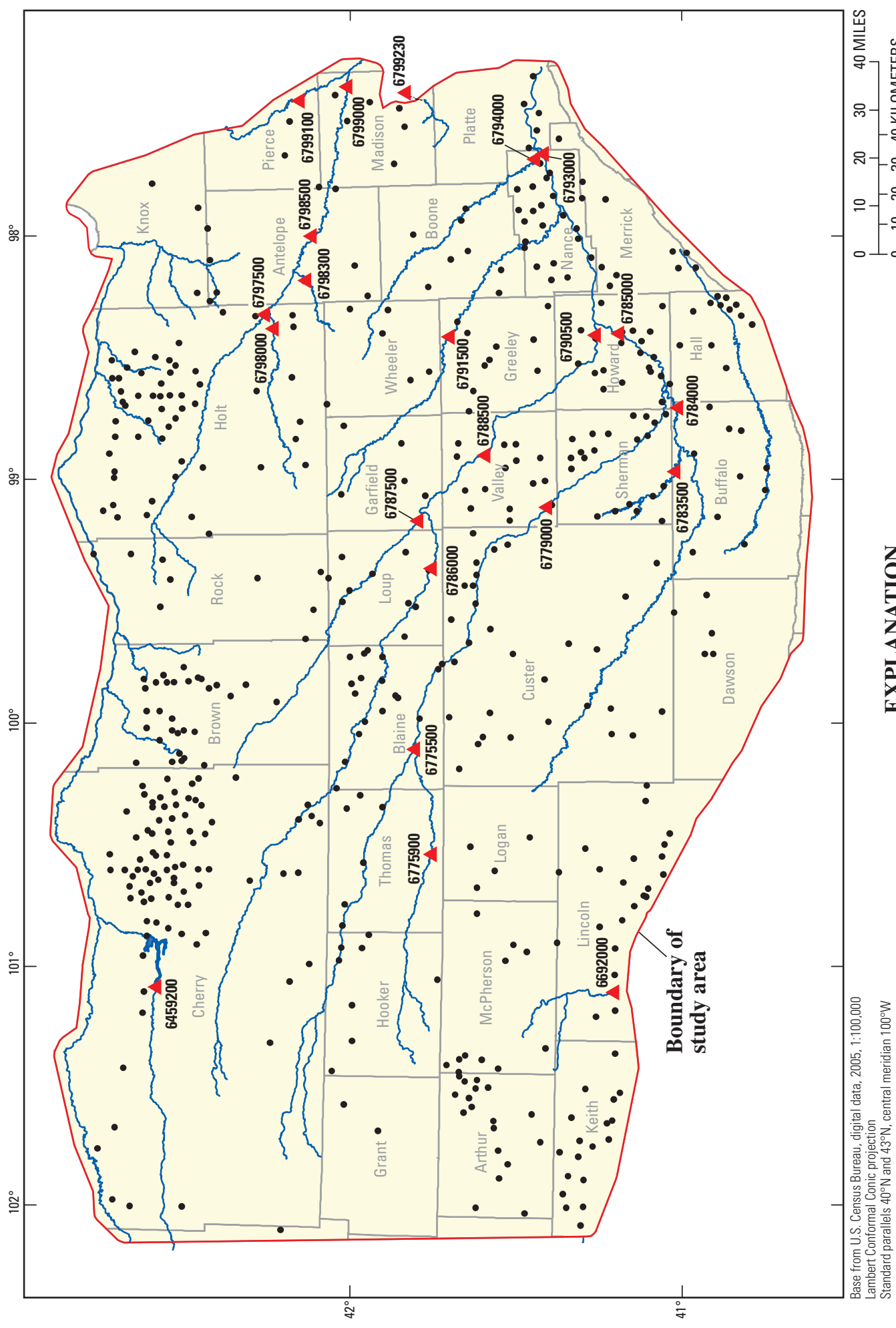

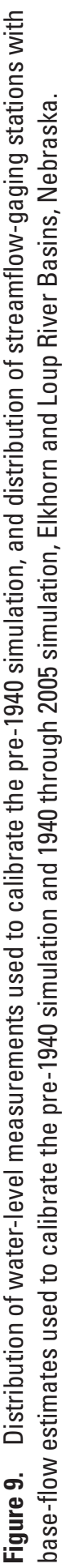


1995 (Conservation and Survey Division, 1996c, 2003). The second $H K$ data set was calculated by dividing transmissivity by saturated thickness. The saturated thickness was calculated by subtracting the interpolated aquifer base from the maximum water-table elevation from either 1979 or 1995 . The maximum water-table elevation from 1979 or 1995 was used to avoid potentially small saturated thicknesses causing unreasonably large $H K$ values. During the calibration process, the $H K$ values represented by regional zones were refined locally using spatially varying values derived from the transmissivity maps and points, except in areas where the water-table aquifer is thin and in narrow buffer zones near most streams. In addition, one area in northeastern Custer, northern Valley, and northern Greeley Counties was assigned a uniform $H K$ that improved simulated water levels and simulated base flow, though that assigned value did not agree with the spatially varying values derived from transmissivity maps (fig. 10). The $H K$ value assigned to that area was 5 feet per day $(\mathrm{ft} / \mathrm{d})$, whereas interpolated $H K$ values in that area were near $20 \mathrm{ft} / \mathrm{d}$. In another area, reported to have high hydraulic conductivities surrounding a low-conductivity area caused by a bedrock high, a more detailed map of $H K$ was used (Cannia and others, 2006) (Buffalo County, western edge of Hall County). The calibrated values of HK are shown in figure 10.

The distribution of recharge from precipitation primarily was based on topographic regions (Conservation and Survey Division, 1997). The largest values of recharge were assigned to areas with sandy soils and level terrain, and the smallest recharge from precipitation was assigned to areas with fine-grained soils and steep slopes. This resulted in a recharge potential for topographic regions being ranked as follows (descending from highest): Sand Hills, valleys, plains, dissected plains, rolling hills, and bluffs and escarpments. The regions shown in figure 2 are from a different source (U.S. Environmental Protection Agency, 2003), but are approximately equivalent to those in Conservation and Survey Division (1997), so an equivalent ranking using regions from figure 2 would be Sand Hills and Sand Hills lakes (Sand Hills), river valleys (valleys), plains and transitional sandy plains (plains), wet meadows and marsh plains (plains), dissected loess plains (dissected plains), loess hills (rolling hills), and river breaks (bluffs and escarpments).

Recharge from precipitation was calibrated by individual topographic regions while maintaining this ranking system, so recharge assigned to the Sand Hills region always was greater than that assigned to the valleys, which was greater than that assigned to the plains, and so forth. This step of the calibration was completed early in the overall calibration process and represented the primary part of the recharge calibration. Recharge assigned to topographic regions was later slightly modified according to average precipitation between 1895 and 2006 (National Climatic Data Center, 2006). Average precipitation for each of the seven climate divisions was used to modify recharge assigned to topographic regions so that areas with smaller or larger long-term average precipitation were assigned smaller or larger recharge values, while maintaining the ranking assigned based on topographic regions. Changes to recharge based on long-term average precipitation were much smaller than changes to recharge based on topographic regions and less important to overall calibration. The ranking of each climate division, from greatest 1895-2006 average annual precipitation to least, was division 6 , division 3 , division 8 , division 5 , division 2 , division 7 , and division 1 . The largest calibrated recharge from precipitation was 3.1 inches per year (in/yr) in the Sand Hills, where recharge ranged from 2.4 to $3.1 \mathrm{in} / \mathrm{yr}$, and ranged from 0.0 to $1.8 \mathrm{in} / \mathrm{yr}$ among the remaining regions (fig. 11).

In order to assign streambed and drain boundary conductance, streams were grouped into three classes according to estimated long-term base flow. The stream group with the largest estimated base flow was assigned the largest conductance value, the stream group with the lowest estimated base flow was assigned the lowest initial conductance, and the remainder of the streams were assigned a value of conductance between the other two values. The streambed conductance values were adjusted for each group individually based on the response of simulated water levels and base flow, while maintaining the ordinal relations among the groups. The conductance assigned to each group was adjusted iteratively, and the values that improved calibration the most were retained.

For the Dismal and Snake Rivers (fig. 12), conductance subsequently was individually calibrated because the simulated base flow initially was too high. For Birdwood Creek, the Elkhorn River, Mud Creek, Plum Creek, and the Snake River, calibration improved when conductance was adjusted to be lowest at the upstream end and increase downstream. As a result of the calibration process, conductance (per foot length in each grid cell) ranged from 0.20 to $31.50 \mathrm{ft} / \mathrm{d}$ (fig. 12). The units of feet per day listed for conductance are not the standard version used in MODFLOW; conductance takes into account the width, thickness, length, and hydraulic conductivity, and has units of square feet per day $\left(\mathrm{ft}^{2} / \mathrm{d}\right)$. However, because GMS 6.0 calculates the length of the stream in each grid cell and applies that to a unit-length conductance assigned to the streambed (fig. 12), the reduced units become feet per day. Smaller streams generally had smaller values.

The maximum annual evapotranspiration rate initially was set uniformly to $14 \mathrm{in} / \mathrm{yr}$, the value estimated at Odessa, Nebr., from measured evapotranspiration rates (Matt Landon, U.S. Geological Survey, oral commun., 2004). During the calibration process, several variations of maximum evapotranspiration rate were tested. Maximum evapotranspiration rates were expected to vary because of climatic conditions across the study area. Therefore, lake evaporation contours (fig. 3; U.S. Weather Bureau, 1959) were used in conjunction with the measured evapotranspiration rate at Odessa to create a spatially variable maximum evapotranspiration rate for input into the simulation. The lake evaporation contours indicate rates are largest in the south and decrease about $10 \mathrm{in} / \mathrm{yr}$ to the smallest rates in the northeast. The mapped variation was combined with the measured evapotranspiration rates at Odessa to generate the maximum evapotranspiration rates for 


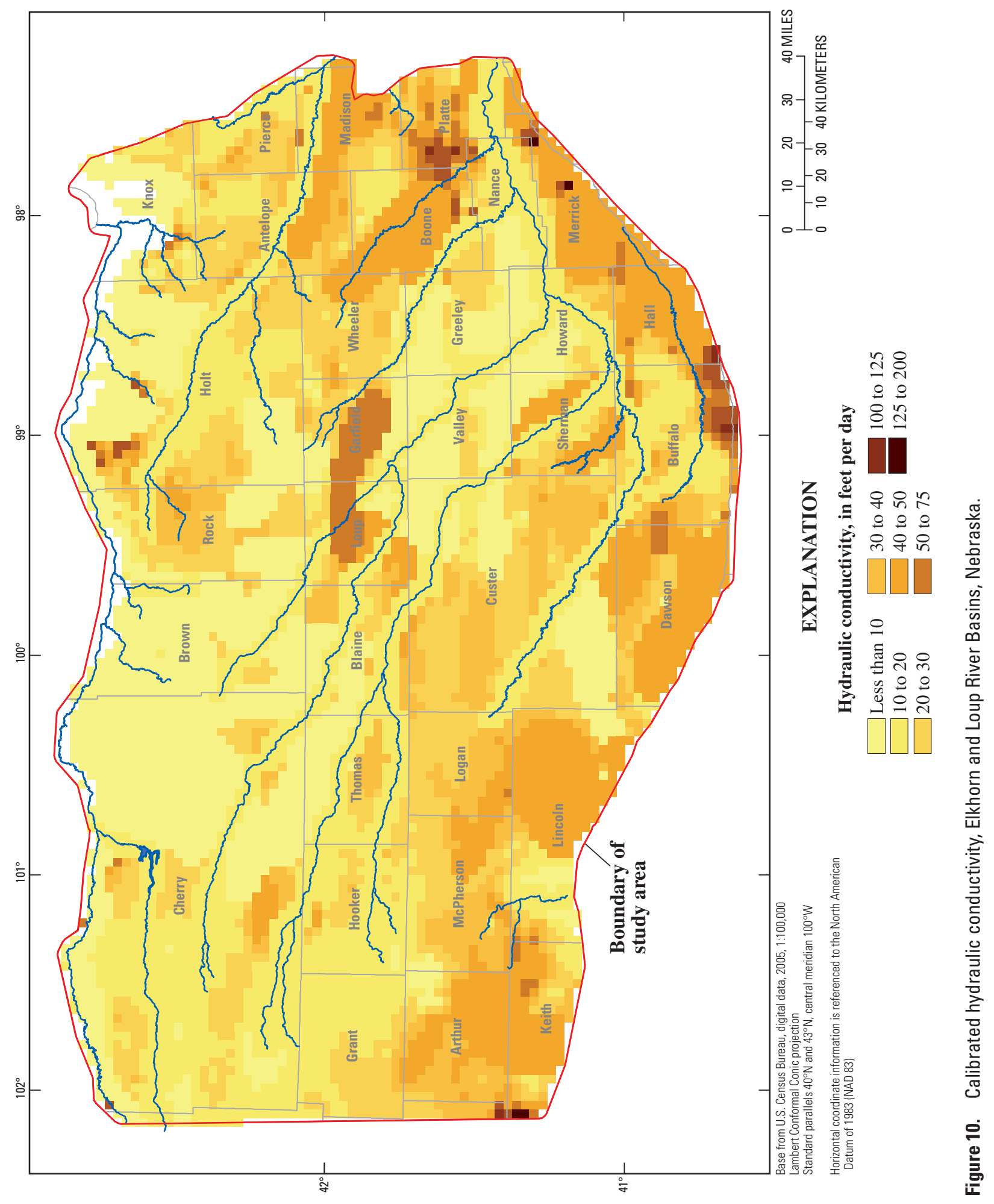




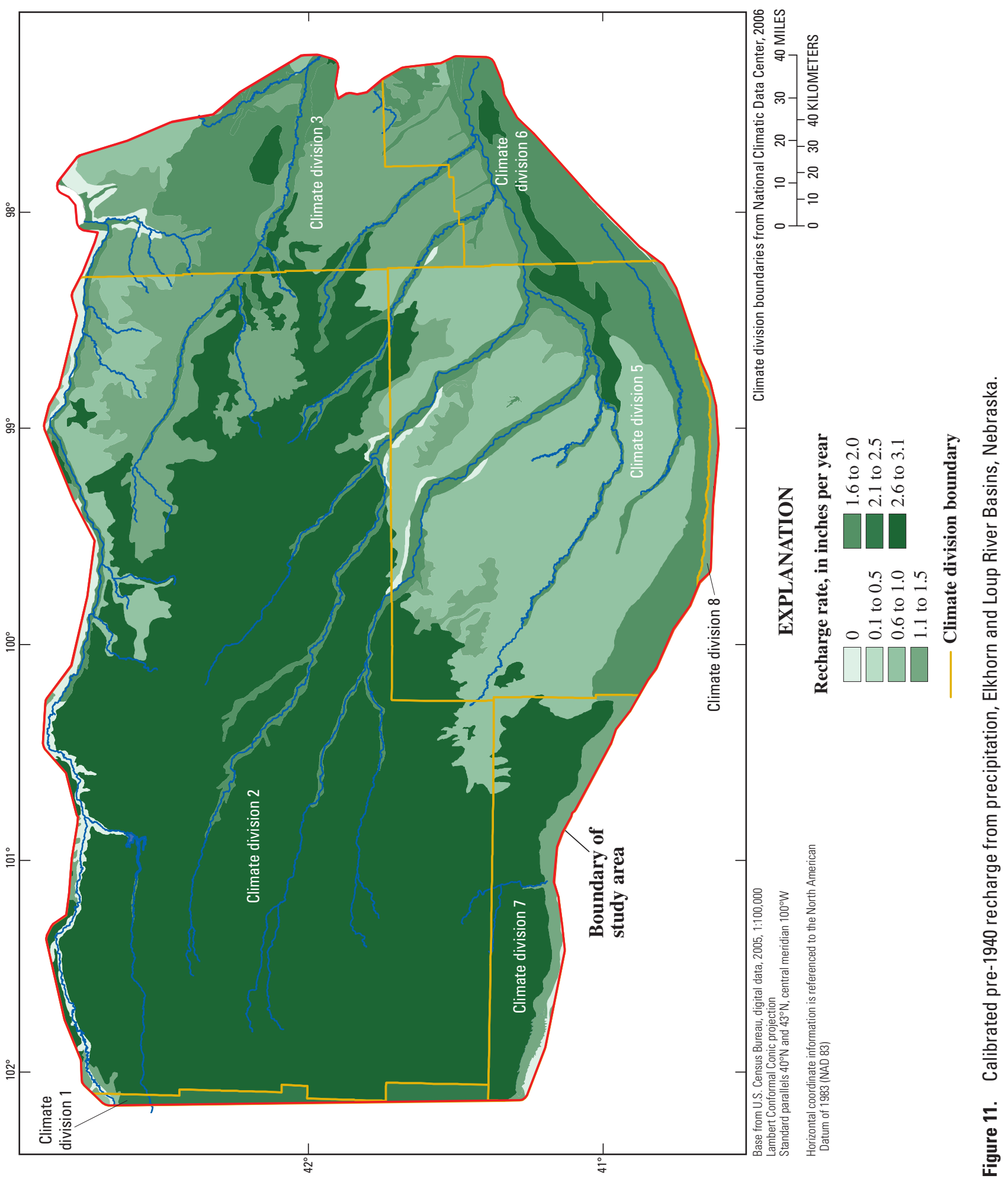




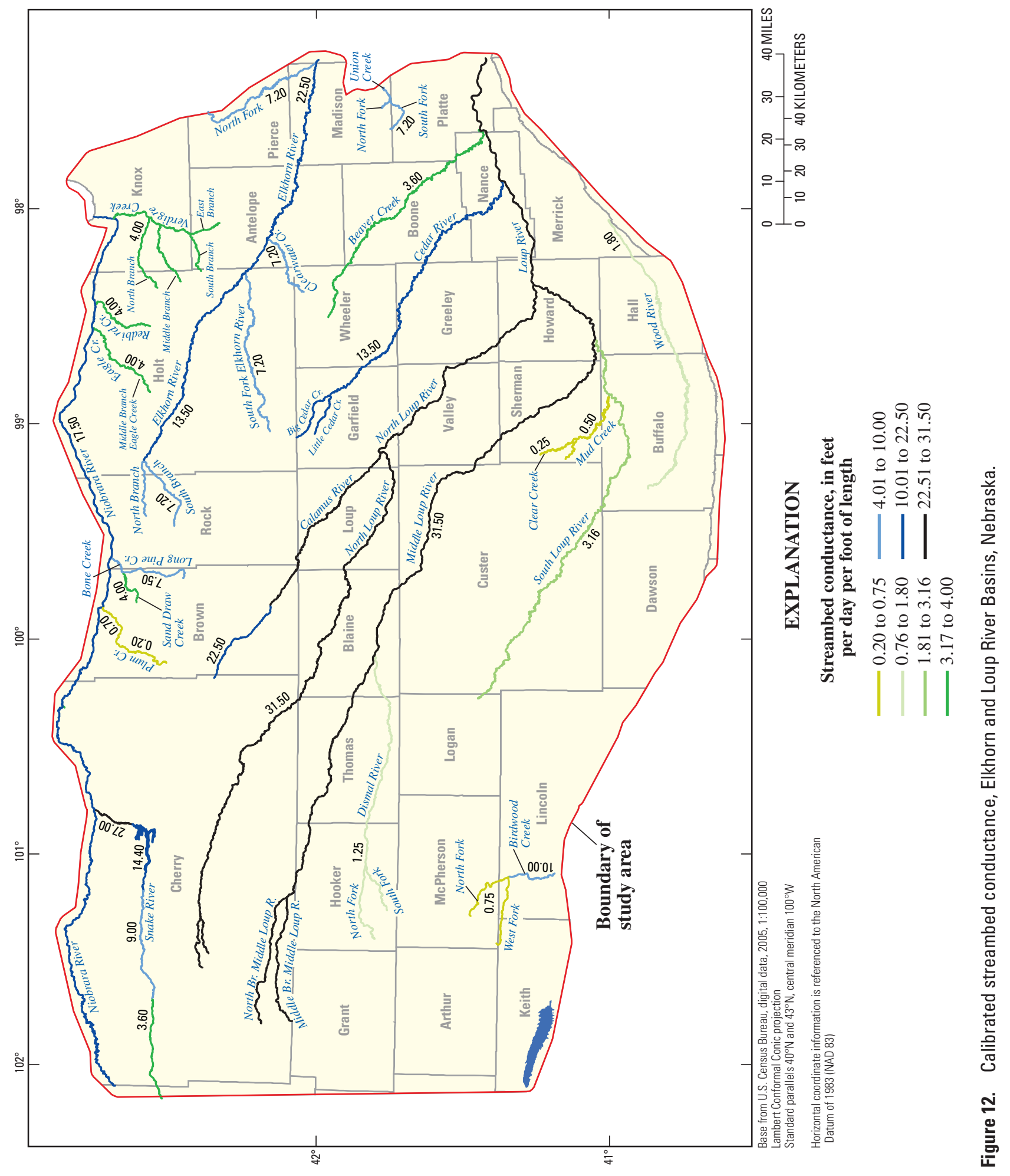


the simulation, which ranged from nearly $15 \mathrm{in} / \mathrm{yr}$ at Odessa to less than $4 \mathrm{in} / \mathrm{yr}$ in the northeast part of the ELM area (fig. 13). Using the mapped contours tied to the measured evapotranspiration rates at Odessa produced a better match between simulated and observed water levels and base flow than using a uniform maximum evapotranspiration rate for the entire area.

\section{Simulation Results}

Simulated steady-state results of the pre-1895 period were not compared to calibration targets because there was not sufficient calibration data against which to check the simulation results. However, 1895 simulated water levels were used as starting water levels for the 1895-1940 simulation, and 1940 simulation results were compared against measured water levels and estimated base flows. The 1940 simulation results were nearly the same as the 1895 results, except in areas affected by canal-seepage recharge included in the 1895 to 1940 simulation, which occurred in only Dawson and Buffalo Counties.

For 45 of the 546 water-level measurements, the observation location was either within a part of the model specified as inactive (fig. 7), or were too near the edge of the simulation for GMS to interpolate a comparison. Simulated 1940 water level was within $30 \mathrm{ft}$ of measured water level for 384 of the remaining 501 points (77 percent) (fig. 14). Simulated 1940 water level was within $60 \mathrm{ft}$ of measured water level at 471 points (94 percent). Differences between simulated and measured water level ranged from -385 to $243 \mathrm{ft}$. Many of the largest differences were near the northern boundary of the ELM area where steep hydraulic gradients exist that may be difficult to simulate accurately with 2-mi grid cells.

Three types of statistical summaries commonly are employed to measure differences between simulated and measured water levels - the mean difference, the mean absolute difference, and the root mean squared (RMS) difference. The mean difference is the mean of all differences between simulated and measured water levels. The mean absolute difference is the mean of the absolute value of the difference between simulated and measured water levels. The RMS difference commonly is referred to as the standard deviation, and is the square root of the mean squared differences between simulated and measured water levels.

The mean difference between the 1940 simulated water level and measured water level was $-3.4 \mathrm{ft}$, indicating that measured water levels generally were higher than simulated water levels. The mean absolute difference was $22.1 \mathrm{ft}$, and the RMS difference was $37.9 \mathrm{ft}$. It generally is accepted that the RMS difference should be a small percentage of the total variation in simulated water levels for the problem domain (Anderson and Woessner, 1992). The RMS difference for this simulation, at $37.9 \mathrm{ft}$, is 1.5 percent of the total variation in simulated water levels, and 1.4 percent of the total relief of the water table in 1979 (about 2,650 ft) (Conservation and Survey Division, 1996c).
Simulated water-level contours for 1940 are shown alongside published interpolated water-level contours for 1979 (Conservation and Survey Division, 1996c) in figure 15. This comparison shows that simulated water levels generally match the published contours; however, the simulated water-level contours are more generalized and fail to represent localized relief in some areas, particularly along the northern boundary of the study area. In some areas, the failure of the simulated contours to match observed water-level contours can be at least partly explained because observed water levels had changed between 1940 and 1979, particularly near canal delivery areas. In addition, the published contours represent a hand-drawn interpretation of water-level data, which therefore also has associated subjectivity; the simulated 1940 contours conversely, were generated using GMS 6.0 and a modified inverse-distance weighted algorithm, and have similar subjectivity though the source of the subjectivity is different. Therefore, differences in the two sets of contours were expected.

Simulated 1940 base flow was compared to estimated long-term base flow for reaches ending at 22 USGS streamflow-gaging stations (table 2). ZONEBUDGET (Harbaugh, 1990) was used to retrieve simulated base flows from the simulation outputs for comparison, with the zones corresponding to the stream cells in between or upstream from streamflow-gaging stations (fig. 9) for which base-flow values were estimated (table 2). Surface-water features in the Niobrara River Basin were not considered as part of the analysis, except for the Snake River. The Snake River is the largest Niobrara River tributary included in the simulation, and was considered large enough to be comparable to the discretization of the regional model; therefore, base flow to the Snake River was considered during calibration. For some of the other Niobrara River tributaries, the regional aquifer may be absent under some parts of the streams, and the base flow of these smaller streams could be controlled by local hydrology not represented in the regional ground-water flow simulation, so these other streams were not considered during calibration.

For ten (45 percent) of the stream reaches considered during calibration, simulated 1940 base flow was within the estimated long-term base-flow range. At four (18 percent) of the reaches, simulated 1940 base flow was larger than the maximum estimated base flow. Simulated 1940 base flow was within 8 percent of the maximum estimate for three of those four reaches. However, the simulated 1940 base flow at Mud Creek near Sweetwater was 95 percent greater than the maximum estimated base flow. For eight (36 percent) of the reaches, simulated 1940 base flow was less than the minimum estimated base flow. Simulated 1940 base flow ranged from 2 to 53 percent less than the minimum estimated base flow. Streams with the smallest volume of estimated base flow had the largest underpredictions. Because these comparisons were calculated as a percentage, streams with smaller base flows mathematically are more likely to have larger errors. In addition, smaller streams are more likely to be simulated poorly with the 2 mi by 2 mi grid spacing used for these simulations. 


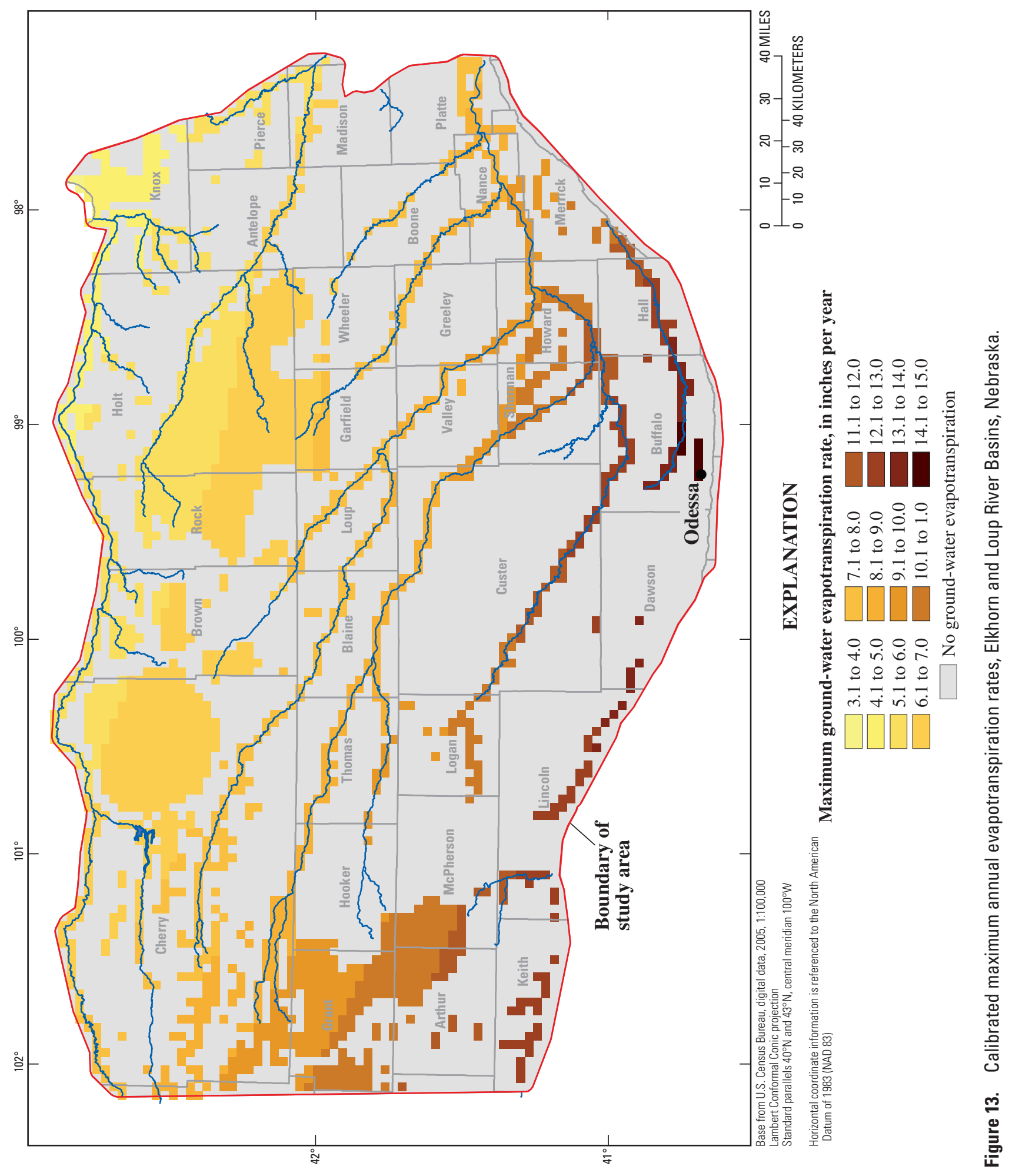




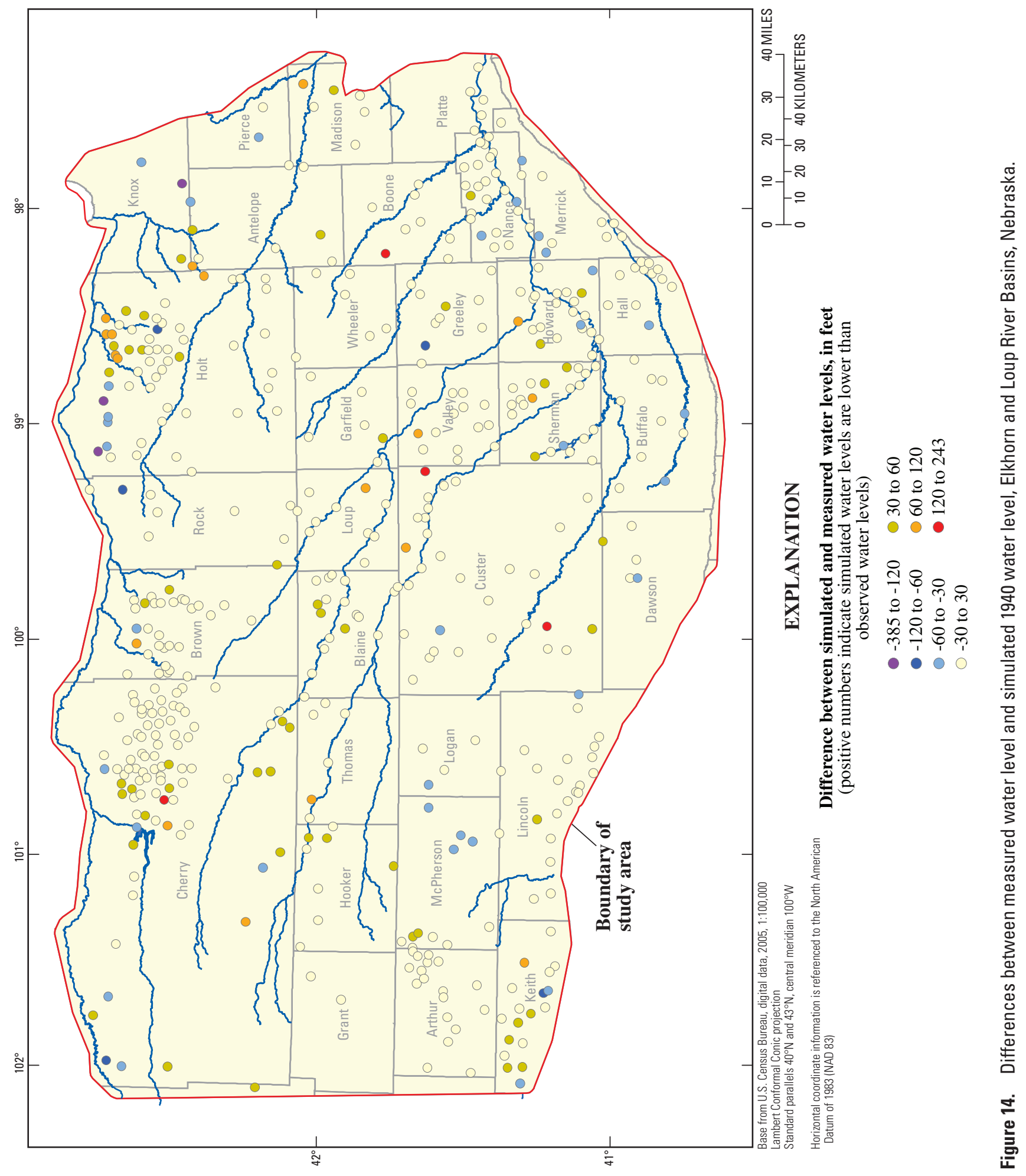




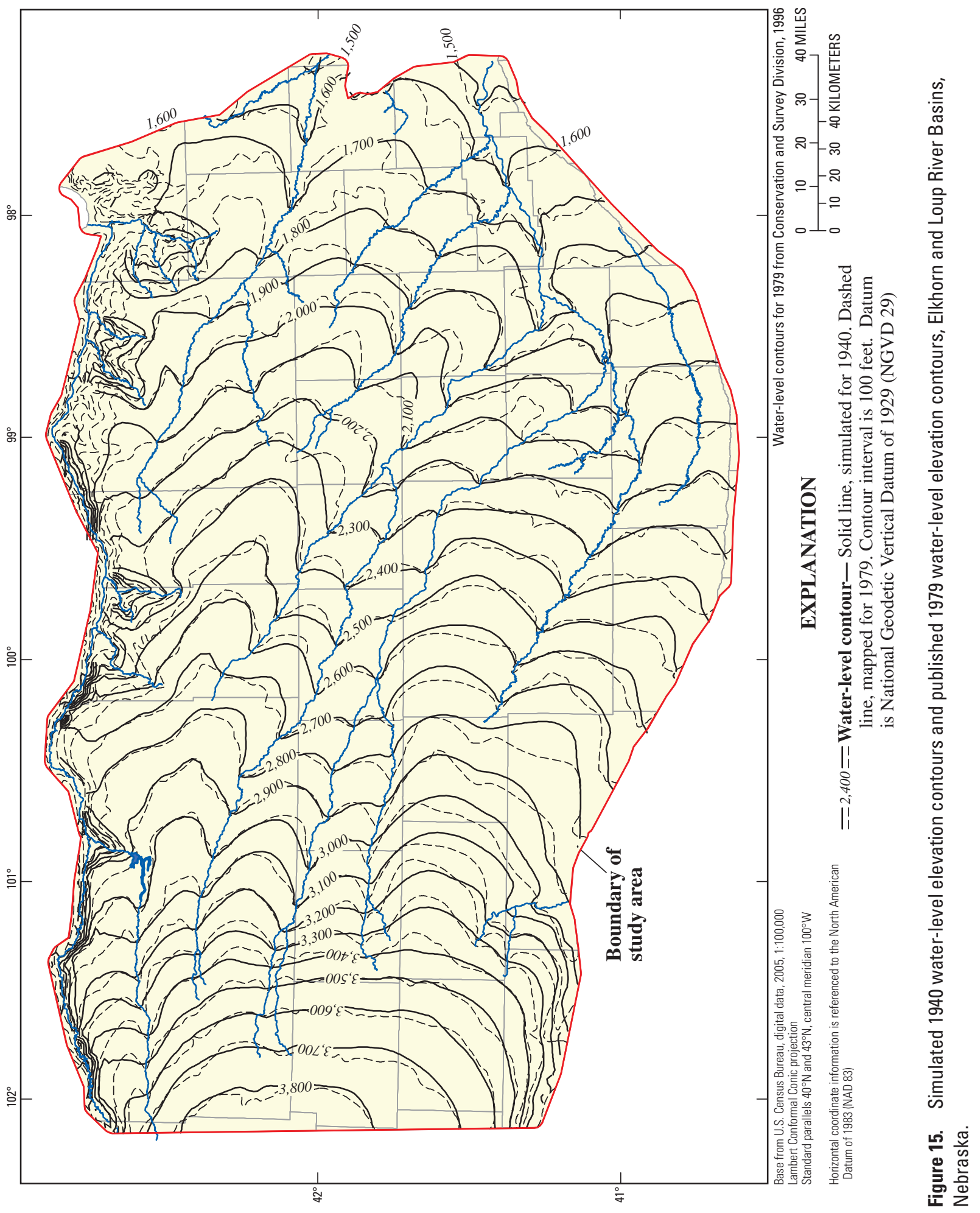


Table 2. Estimated minimum and maximum base flow compared with simulated 1940 and 2005 base flow, Elkhorn and Loup River Basins, Nebraska.

[( ) number in parentheses indicates that stream had a net loss of water to the aquifer]

\begin{tabular}{|c|c|c|c|c|c|}
\hline \multirow{2}{*}{$\begin{array}{l}\text { U.S. Geological Survey streamflow-gaging } \\
\text { station and number }\end{array}$} & \multicolumn{2}{|c|}{$\begin{array}{l}\text { Estimated long-term base } \\
\text { flow, in acre-feet per year }\end{array}$} & \multirow{2}{*}{$\begin{array}{c}\text { Period of record } \\
\text { (start year, end year, } \\
\text { number of years of data) }\end{array}$} & \multicolumn{2}{|c|}{$\begin{array}{c}\text { Simulated base flow, in } \\
\text { acre-feet per year }\end{array}$} \\
\hline & Minimum & Maximum & & $\begin{array}{l}\text { To streams } \\
\text { in } 1940\end{array}$ & $\begin{array}{l}\text { To streams } \\
\text { in } 2005\end{array}$ \\
\hline \multicolumn{6}{|c|}{ Niobrara River Basin } \\
\hline Snake River above Merritt Reservoir (06459200) & 135,000 & 138,000 & $(1963,1980,18)$ & 135,000 & 139,000 \\
\hline South Fork Elkhorn River at Ewing (06798000) & 21,200 & 23,000 & $(1947,1990,32)$ & 19,000 & 18,400 \\
\hline Clearwater Creek near Clearwater (06798300) & 16,400 & 17,100 & $(1961,1990,17)$ & 10,300 & 9,290 \\
\hline Elkhorn River at Neligh (06798500) & 9,530 & 44,800 & $(1931,1992,60)$ & 28,700 & 29,200 \\
\hline Elkhorn River at Norfolk (06799000) & 59,000 & 94,000 & $(1896,2003,59)$ & 57,100 & 60,300 \\
\hline Middle Loup River at Dunning (06775500) & 276,000 & 283,000 & $(1946,2003,58)$ & 279,000 & 280,000 \\
\hline Dismal River near Thedford (06775900) & 138,000 & 140,000 & $(1967,2003,37)$ & 140,000 & 141,000 \\
\hline Middle Loup River at Arcadia (06779000) & 85,000 & 240,000 & $(1937,1995,57)$ & 126,000 & 153,000 \\
\hline Mud Creek near Sweetwater (06783500) & 7,750 & 7,900 & $(1946,1994,48)$ & 15,400 & 14,600 \\
\hline South Loup River at St. Michael (06784000) & 100,000 & 131,000 & $(1944,2003,60)$ & 139,000 & 132,000 \\
\hline Middle Loup River at St. Paul (06785000) & $(101,000)$ & 182,000 & $(1928,2003,75)$ & 42,900 & 78,700 \\
\hline North Loup River at Taylor (06786000) & 303,000 & 321,000 & $(1937,2003,67)$ & 305,000 & 312,000 \\
\hline Calamus River near Burwell (06787500) & 179,000 & 192,000 & $(1941,1995,55)$ & 175,000 & 179,000 \\
\hline Birdwood Creek near Hershey (06692000) & 98,500 & 102,000 & $(1931,1990,59)$ & 103,000 & 104,000 \\
\hline
\end{tabular}

For the calibrated pre-1940 simulation, 83 percent of water entering the water-table aquifer (inflow) was from recharge from precipitation (table 3). Other sources of water were loss of stream base flow (13 percent), canal-seepage recharge ( 3 percent), and fixed water-level boundaries ( 1 percent). Ground-water discharge to stream base flow accounted for 61 percent of the water leaving the water-table aquifer (outflow). Water also was lost from the water-table aquifer by evapotranspiration (22 percent), fixed water-level boundaries ( 8 percent), base flow to drain boundaries ( 7 percent), and water entering storage (1 percent).

\section{0 through 2005 Simulation}

The 1940 through 2005 transient simulation included inputs associated with ground-water irrigation, in addition to simulation inputs used to simulate the pre-1940 period. The 1940 through 2005 simulation also included additional recharge from precipitation applied to nonirrigated and irrigated cropland areas, additional recharge applied to Hall and Buffalo Counties, canal-seepage recharge from existing canals (as well as recharge resulting from canals that began operation after 1940), pumpage for irrigation, pumpage for municipal water supplies, and a general-head boundary simulating seepage to and from Lake McConaughy. 
Table 3. Simulated ground-water budget for the pre-1940 simulation, Elkhorn and Loup River Basins, Nebraska.

[--, not applicable]

\begin{tabular}{|c|c|c|c|c|}
\hline \multirow[b]{2}{*}{ Budget component } & \multicolumn{2}{|c|}{ Inflows } & \multicolumn{2}{|c|}{ Outflows } \\
\hline & $\begin{array}{c}\text { Thousands of acre-feet } \\
\text { per year }\end{array}$ & Percent of budget & $\begin{array}{c}\text { Thousands of acre-feet } \\
\text { per year }\end{array}$ & Percent of budget \\
\hline Fixed-water level boundaries & 42 & 1 & 343 & 8 \\
\hline All recharge & 3,546 & 86 & -- & -- \\
\hline Base flow to/from stream boundaries & 528 & 13 & 2,529 & 61 \\
\hline Base flow to drain boundaries & -- & -- & 298 & 7 \\
\hline Evapotranspiration & -- & -- & 898 & 22 \\
\hline TOTAL & 4,116 & 100 & 4,116 & 199 \\
\hline
\end{tabular}

${ }^{1}$ Does not total 100 percent because of rounding.

\section{Estimation of Historical Land Use}

Estimated pumpage for irrigation and a part of the recharge applied to the 1940 through 2005 simulation were dependent on the annual distribution of land-use classes. However, previously existing land-use data did not provide information about the distribution of crops irrigated with ground water or surface water or the distribution of nonirrigated crops, so these distributions had to be estimated.

Historical estimates of the distribution of these three land- and water-use categories were determined from a combination of data sources. Mapped locations of rangeland and cropland obtained from the National Agricultural Statistics Service (NASS) provided the basic distribution of land use within each grid cell in 2005 (U.S. Department of Agriculture, 2006). However, the NASS map did not classify irrigated and nonirrigated crops separately, as was necessary for the simulation. Therefore, the initial NASS data were evaluated by grid cell and compared to maps of surface-water irrigation districts, whereby some acres were classified as surface-water irrigated. Some acres were then assigned as irrigated with ground water using other data, and the remainder of the crop acres was classified as nonirrigated.

Maps of surface-water irrigated areas and tables of total acres irrigated by surface water were provided by Rick Vollertsen (Nebraska Department of Natural Resources, written commun., 2005), Allan Schmidt (Middle Loup Public Power and Irrigation District, written commun., 2006), Mel Brozek (Sargent Irrigation District, written commun., 2006), Jack Wergen (U.S. Bureau of Reclamation, written commun., 2006), Darwin Lee (Farwell Irrigation District, written commun., 2006), William Peck (U.S. Bureau of Reclamation, written commun., 2006), and Ron Wolfe (Twin Loups Irrigation District, written commun., 2006). The district boundaries (assigned to grid cells, fig. 8) and number of irrigated acres within each surface-water district are thought to be reasonably accurate, but the distribution of these acres within the boundaries of some of the districts is not well defined. For surfacewater districts where the distribution of irrigated acres within the district was not well constrained, the acres were divided evenly among all grid cells within the district area.

To classify cropland acres as nonirrigated, surface-water irrigated, or ground-water irrigated, surface-water irrigated acres were first subtracted from each grid cell. The remaining cropland acres in the cell, which had the potential to be irrigated by ground water, were separated into nonirrigated and ground-water irrigated land by comparing the location of the cropland against the locations of active registered irrigation wells and the number of acres reported as irrigated in the well registration database (Nebraska Department of Natural Resources, 2005a). If the number of cropland acres in the cell was less than the acres attributed to registered irrigation wells in that grid cell, then all the remaining cropland acres were classified as ground-water irrigated; if the number of irrigated acres in the registered-well database was less than the remaining cropland in the cell, then the number of ground-water irrigated acres for that cell was set equal to the number of irrigated acres in the registered-well database, and the remainder was classified as nonirrigated. In addition, to limit potential errors that could have been caused by the assumptions implicit in using the irrigated acres associated with registered wells, the number of acres classified as ground-water irrigated in each county in 2005 was adjusted later to match the county totals from the 2005 land-use map (Center for Advanced Land Management Information Technologies, 2007), which was not available during the initial land-use estimation process.

Pre-2005 land-use data were estimated based on countylevel crop statistics in the Census of Agriculture (U.S. Department of Agriculture, variously dated). The Census of Agriculture provided the number of nonirrigated and irrigated acres for each crop grown in each county every 5 years from 1950 to 2002. To produce the annual data required for the 1940 
through 2005 simulation, yearly county-level values were interpolated between the data values provided every 5 years for 1950 to 2002. Crop acres from 1940 to 1949 were set to 1950 values. The mapped land use for 2005 was adjusted by a multiplier so that the total for each county for 2004 and preceding years matched the data interpolated from the Census of Agriculture data for each year. In the final data set used for the simulation, the number of acres assigned to each classification in each county matched the Census of Agriculture county-level statistics or the interpolation between the published years. If a county was only partially within the study area, the number of acres of each irrigated and nonirrigated crop was reduced by the proportion of the county that was outside the study area.

\section{Simulation Inputs}

This section describes simulation inputs that were not adjusted during calibration, including pumpage for irrigation, pumpage for municipal uses, canal-seepage recharge, and elevation assigned to a general head boundary representing Lake McConaughy. Unless described here or in the "Calibration Process" section, all other inputs remained the same as those used in the pre-1940 simulation.

The amount of pumpage for irrigation in the study area historically has not been measured. Therefore, annual pumpage for irrigation was estimated to be equal to the expected crop-water demand minus growing-season effective precipitation (the amount of precipitation available for crop consumption). The growing season is defined to be approximately May through September; effective precipitation is total precipitation minus the part that becomes runoff.

Crop-water requirements for each grid cell were based on the number of acres of each crop grown and the amount of water required to produce each of those crops (University of Nebraska, 1990 and 2002). Individual crop requirements were $25.5 \mathrm{in} / \mathrm{yr}$ for corn, $22 \mathrm{in} / \mathrm{yr}$ for soybeans, $20.5 \mathrm{in} / \mathrm{yr}$ for sorghum, $15.5 \mathrm{in} / \mathrm{yr}$ for dry beans, $33.5 \mathrm{in} / \mathrm{yr}$ for alfalfa, $23.2 \mathrm{in} / \mathrm{yr}$ for potatoes, and $17 \mathrm{in} / \mathrm{yr}$ for small grains and sunflowers. Individual crop water requirements were summed to yield a total water requirement for ground-water irrigated crops in each cell. All pumpage was calculated as net pumpage, which is the portion actually used by the crops and therefore lost to the system. Actual pumpage probably would be higher than net pumpage because of on-farm losses of pumped water before it could be applied to the crops. However, it was assumed that the major portion of the on-farm losses returns to the ground-water system as recharge, so on-farm losses were ignored for these calculations. The crops grown in each grid cell were estimated as described in the "Estimation of Historic Land Use" section of this report. Pumpage for irrigation was assigned only where the estimation indicated ground-water irrigated crops were present.

Estimated effective precipitation (precipitation that does not run off) was calculated for each year from 1940 through 2005 by adjusting growing season precipitation in each climate division (National Climatic Data Center, 2006) with
Soil Conservation Service (SCS) rainfall-runoff curves for soil class A (U.S. Department of Agriculture, 1986; Woodward and others, 2002). Soil classes B, C, and D were assigned the same adjusted effective precipitation values as soil class A because soil class B data were not substantially different than soil class A data and because soil classes $\mathrm{C}$ and $\mathrm{D}$ did not compose large parts of the study area. The estimated effective precipitation for each growing season (defined in this report as May through September) was subtracted from the total water requirement of all crops to calculate the actual amount of water needed by crops that had been unmet by precipitation. Negative values indicated that the total water requirement for that cell would have been met by effective precipitation, in which case pumpage was set to zero.

Calculated pumpage for irrigation was then compared with available measured pumpage for 2005 (Russ Callan, Lower Loup Natural Resources District, written commun., 2007; Tylr Naprstek, Upper Elkhorn Natural Resources District, written commun., 2007) to determine whether or not the estimated pumpage rates should be adjusted. The average calculated volume of water pumped for corn in 2005 of $9.9 \mathrm{in} / \mathrm{yr}$ was compared to the average measured volume of water pumped for corn in 2005 minus an efficiency factor to account for on-farm losses, or about $6.5 \mathrm{in} / \mathrm{yr}$. The original effective precipitation values were then modified by the difference between the calculated and measured pumping volumes for corn for 2005 (3.4 in/yr), for all years from 1940 through 2005. Finally, the modified effective precipitation values were subtracted from the combined water requirement for all crops to yield the final estimate of pumpage for irrigation for all years. Negative values indicated that the total water requirement for that cell would have been met by effective precipitation, in which case pumpage was set to zero. Total estimated yearly pumpage and the parts for corn and soybeans are shown in figure 16.

The amount of pumpage for municipal water supplies was obtained from the measured pumpage reported by municipalities in the study area (Shuhai Zheng, Nebraska Department of Natural Resources, written commun., 2007). Most of the reported pumpage data were from 2004; however, some values were from 2001 to 2003 or 2005 . The reported pumpage rates were applied as a constant value to all years in the simulated 1940 through 2005 period.

In addition to the five canal systems in operation during the pre-1940 period, seven irrigation districts began operating new canal systems during the 1940 through 2005 period. The Birdwood Irrigation District started diverting water in 1946, Middle Loup Public Power and Irrigation District and North Loup Irrigation District started in 1947, Sargent Irrigation District started in 1957, Farwell Irrigation District started in 1963, Ainsworth Irrigation District started in 1965, and the Twin Loups Irrigation District started in 1987 (fig. 8). The only canal system that ceased operation during the 1940 through 2005 period was Elm Creek Canal (in 1962).

Calculated canal and lateral losses (canal seepage) based on water-mass balance were available for at least part of the 


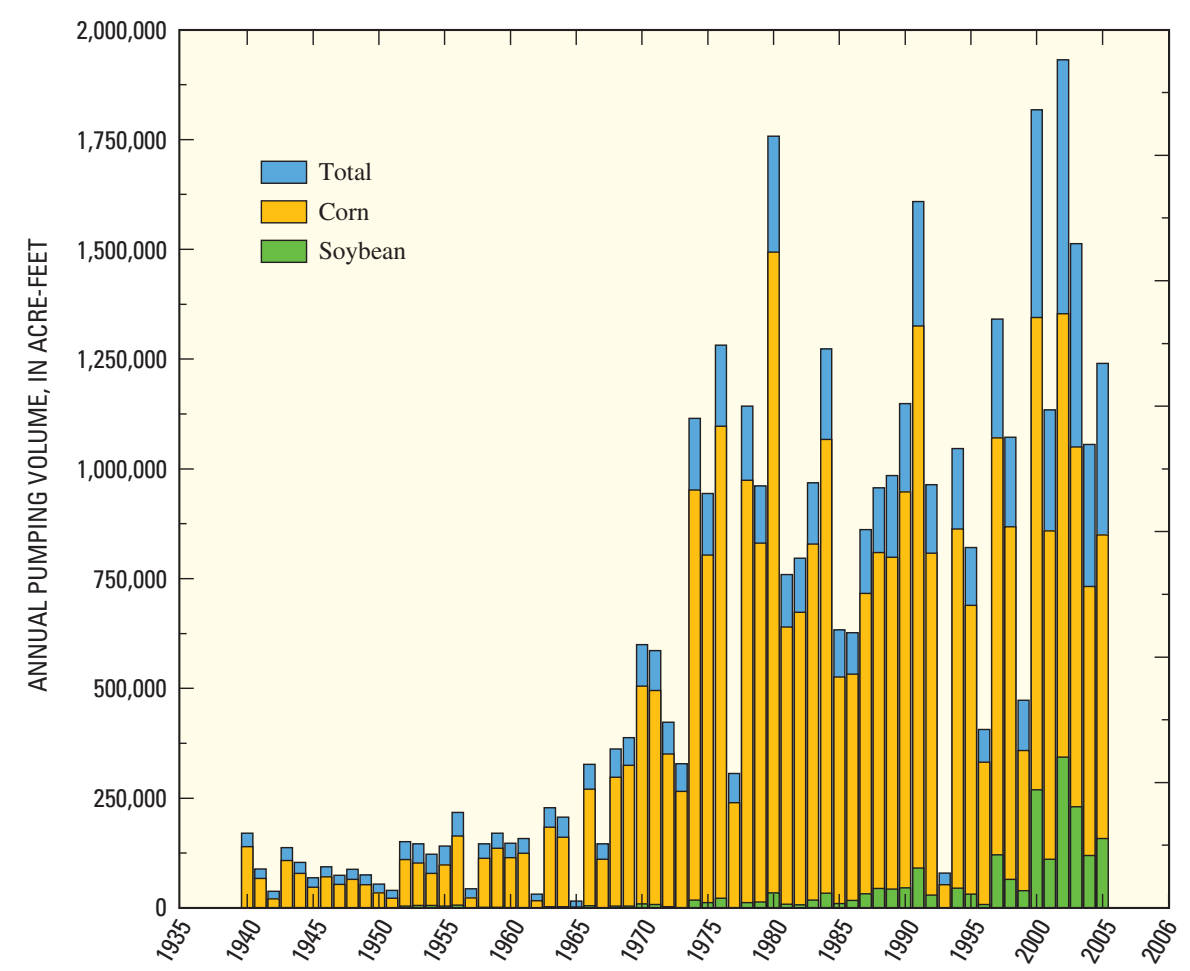

Figure 16. Yearly estimated pumpage for corn, soybeans, and total pumpage, Elkhorn and Loup River Basins, Nebraska, 1940 through 2005.
1940 through 2005 period for Middle Loup (Allan Schmidt, Middle Loup Public Power and Irrigation District, written commun., 2006), Sargent (Mel Brozek, Sargent Irrigation District, written commun., 2006), Farwell (Jack Wergen, Bureau of Reclamation, written commun., 2006, and Darwin Lee, Farwell Irrigation District, written commun., 2006), Ainsworth (William Peck, Bureau of Reclamation, written commun., 2006), and Twin Loups (Ron Wolfe, Twin Loups Irrigation District, written commun., 2006) Irrigation Districts. For all other irrigation districts and canal systems, canal seepage was estimated to be 43 percent of the total diverted water minus return flows, based on previous work (Duane Woodward, Central Platte NRD, oral commun., 2002) (fig. 17).

Lake McConaughy was represented in the simulation as a general-head boundary. This reservoir began storing water in 1940, reaching average storage capacity by about 1947 . Water-level elevations from the end of the pre-1940 simulation were used as the starting water levels for the general-head boundary, as they were in the rest of the simulation domain. Though it was considered unlikely that changes in lake stage would have any major or far-reaching effects in the interior of the simulation area, analysis of readily available annual lake stage data (C. Steinke, Central Nebraska Public Power and Irrigation District, written commun., 2007) indicated variations in lake stage of tens of feet during 1940 through 2005. If any measured water-level changes that were to be used as observations had been near the lake, they could have been affected by these stage changes. Therefore, annual lake-stage elevations were assigned to the simulated 1940 through 2005 general-head boundary. For the parts of the model representing the lake, water-level elevations were set to the starting water- level elevations from the pre-1940 simulation if the lake-stage elevation was lower than the starting water-level elevation. Conductance for the general-head boundary was tested during simulation calibration and is discussed in the "Calibration Process" section of this report for the 1940 through 2005 simulation.

\section{Calibration Targets}

Though the starting water levels for the 1940 through 2005 simulation were the simulated 1940 water levels, uncertainty and misfit between the simulated 1940 water levels and the measured water levels probably would have biased a comparison of absolute water levels simulated from 1940 through 2005 against measured water levels. Therefore, simulated and measured water-level changes were used as the calibration targets because they provided a more clear indication of simulation calibration to conditions for the 1940 through 2005 period only (and various intermediate periods), rather than potentially being affected by errors that could have been present in the pre-1940 simulated water levels.

Ground-water level changes were calculated for the simulated and measured water levels in 10-year increments (1945-55, 1955-65, 1965-75, 1975-85, 1985-95, and 1995-2005) as well as for most of the simulation period (1945 to 2005). To obtain the largest number of calibration points, measured water levels (targets) were selected separately by decade from all available water-level measurements. For example, to calculate 1945-55 water-level change a well should have had measured water levels representing 1945 and 1955 , but wells were not always measured in those specific 


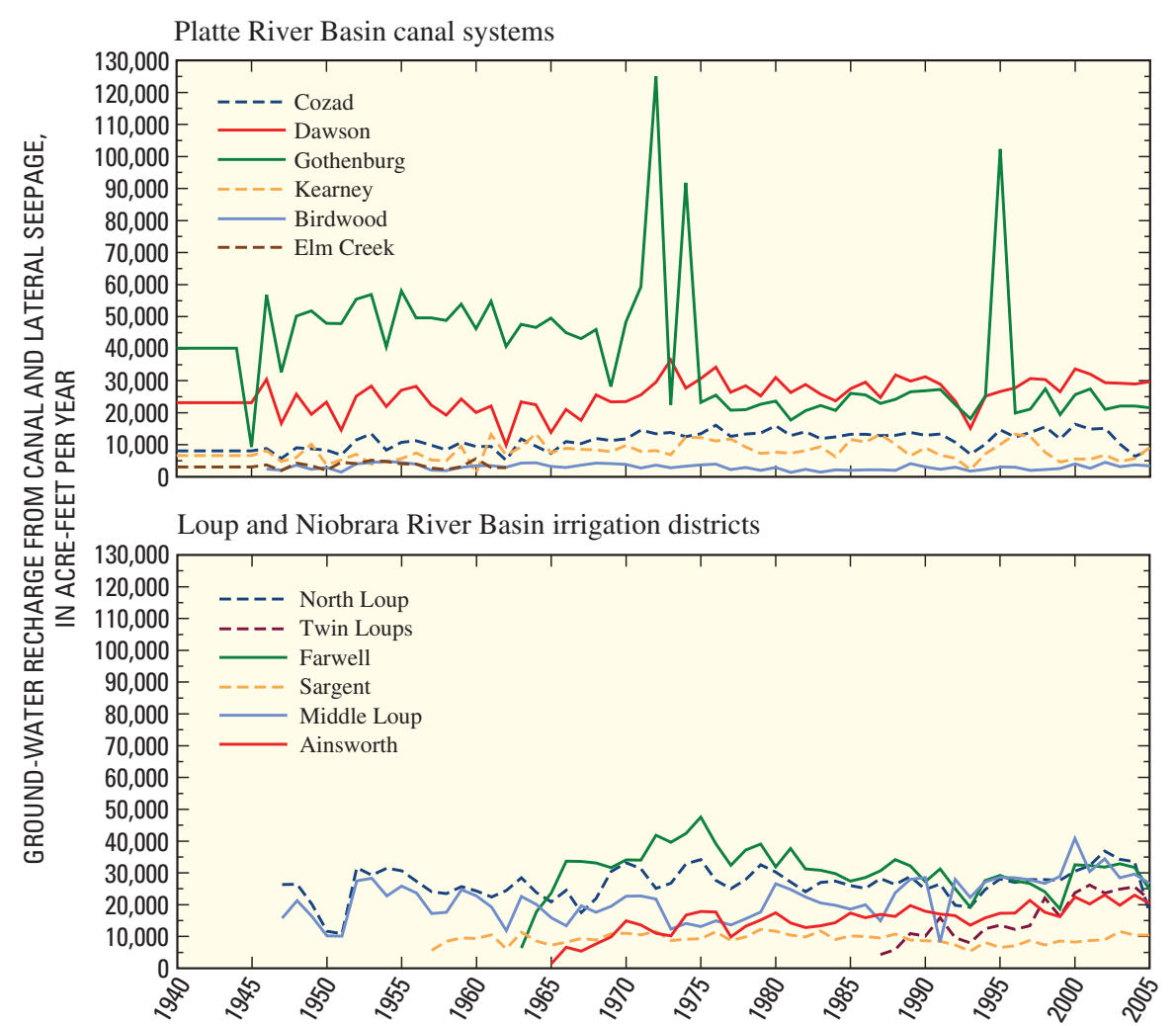

Figure 17. Estimated recharge from canal and lateral seepage, 1940 through 2005, Elkhorn and Loup River Basins, Nebraska. years. Therefore, the measurement for 1945 would have been the measurement made between 1940 and 1949 closest to 1945, and the measurement for 1955 would have been the measurement made between 1950 and 1959 closest to 1955 . In addition, some water levels randomly were removed from certain small areas of each set if many wells had been measured in that small area, because in many parts of the study area there were few measurements made or long distances between measured wells. This reduced the tendency for the areas with many measurements to obscure the calibration response of areas with fewer points.

The final set of measured water-level changes was not distributed evenly across the study area, nor was there an equal number for all time periods. Generally, there were more measured water levels in recent times than in early times; therefore, the 1995 through 2005 period had the most waterlevel changes.

Simulated 2005 base flow was compared with the same estimated long-term base flow used for the pre-1940 calibration. The same approach was used with respect to simulated 2005 base flow as was used for simulated 1940 base flow; if the simulated 2005 base flow was about the same as the estimated long-term base flow, the simulation was considered calibrated with respect to those base flows.

\section{Calibration Process}

As described previously in this report, estimated pumpage for irrigation was constrained using the best information available, so it was not adjusted during calibration of the 1940 through 2005 simulation. Recharge from precipitation occurring on unbroken (non-agricultural) lands was maintained at the same recharge from precipitation values used for the pre-1940 simulation. Canal-seepage recharge was estimated and also not adjusted during the calibration process. Pumpage for irrigation, when added to the 1940 through 2005 simulation, represents a substantial ground-water withdrawal; without an additional source of water, simulated water levels declined during the 1940 through 2005 period, though measured declines generally have not occurred in the study area. Therefore, the primary calibration strategy was to calibrate the simulation by increasing recharge applied to nonirrigated and irrigated cropland areas to balance the estimated (net) pumpage until simulated and measured water-level changes matched acceptably while ensuring that simulated 2005 base flows reasonably matched estimated base flows.

The conceptual model for enhanced recharge applied to agricultural cropland areas is that lands that have been plowed and that are used to grow crops allow precipitation to infiltrate more easily than those areas that remain unbroken (Scanlon and others, 2005). Similarly, the practice of irrigation causes soil moisture to be greater under irrigated agricultural lands; therefore, precipitation that occurs on irrigated lands also can infiltrate more easily and has a better chance of becoming recharge than precipitation that occurs on broken lands such as nonirrigated cropland (Luckey and Cannia, 2006). Therefore, areas with nonirrigated crops should allow more recharge from precipitation than unbroken lands, and areas with irrigated crops should allow more recharge than areas with nonirrigated 
crops. This concept of recharge is similar to that reported by Scanlon and others (2005), that recharge was greater under cultivated lands than under unbroken lands.

The rate of simulated recharge applied for these land classes to calibrate the simulation did not change with time during the 1940 through 2005 period, though the total amount of recharge did change with time as the amount of land classified as irrigated, nonirrigated, and rangeland changed. Recharge rate in the simulation was a calibration parameter and it is not known how the calibrated recharge compares to actually occurring recharge at a regional scale. However, if recharge rates applied to calibrate the simulation are similar to regionally occurring recharge rates, simulated recharge could be considered the long-term average recharge that occurred from that land classification type.

For recharge from precipitation occurring on nonirrigated and irrigated cropland areas, the iterative calibration process resulted in nonirrigated cropland areas allowing $0.5 \mathrm{in} / \mathrm{yr}$ more than recharge from precipitation applied to unbroken lands, and irrigated cropland areas allowing $3.5 \mathrm{in} / \mathrm{yr}$ more than recharge from precipitation applied to unbroken lands.

In addition, throughout the calibration process, simulated ground-water level declines consistently were larger than measured declines in an area of intense irrigation covering most of Hall County, southeast Buffalo County, and a small part of western Merrick County. Therefore, an additional 1 in/yr of recharge was added to the rate of recharge applied to irrigated lands in this area for 1970 through 2005, the period of most intense irrigation, to improve the calibration. This area may allow additional recharge because more fields are irrigated with gravity irrigation systems rather than the sprinkler irrigation systems more commonly used in other parts of the study area. Gravity irrigation systems typically lose more water to deep percolation than do sprinkler systems (Eisenhauer and others, 1996). In addition, it has been recognized that farmers in this area frequently dike the downgradient ends of fields (Duane Woodward, Central Platte Natural Resources District, oral commun., 2004). Diking field ends is not widely practiced throughout the rest of the study area but also would increase recharge by reducing runoff.

The conductance of the Lake McConaughy general-head boundary was adjusted during simulation calibration to test whether or not increasing or decreasing conductance from the initial estimate would improve the simulated water-level changes. Initial conductance values ranged from 0.08 to $2.50 \mathrm{ft}^{2} / \mathrm{d}$ per unit area. The range of conductance values tested was considered to be the range of reasonable values for lakebed conductance by multiplying initial values by 0.4 and then by 20 , but simulated water-level changes were not affected within this range; therefore, conductance of the Lake McConaughy general-head boundary was not changed.

\section{Simulation Results}

A statistical summary of the differences between the simulated and measured water-level changes for each 10-year time period and for 1945 through 2005 is shown in table 4 . Spatial comparisons of simulated and measured water-level change for each time period are shown in figures 18-24. In many areas, neither simulated nor measured water levels changed more than $5 \mathrm{ft}$ during a particular 10-year time period, and water-level changes were similar for simulated and measured values. However, several areas did not indicate agreement between simulated and measured water-level change. In the area of Cozad and Gothenburg Canal systems (fig. 8), the model simulated water-level rises from 1945 to 1955 that are not present in measured water-level changes, and the simulated changes from 1975 to 1985 were declines whereas measured water levels remained the same or rose. Simulated water-level rises for 1985 to 1995 were smaller than measured water-level rises in several parts of the study area, including the areas of the Twin Loups Irrigation District and Wheeler County. Simulated water-level declines for 1995 to 2005 were less than measured water-level declines between the South Loup/Loup River and the southern simulation boundary, and simulated water-level rises were less than measured waterlevel rises in the area of the Twin Loups Irrigation District.

Only 42 sites had a measured water level in both the 1940s and the 2000s and most were along the southern edge of the study area. Of those sites, 60 percent ( 25 of 42 ) had a simulated water-level change within $5 \mathrm{ft}$ of measured waterlevel change. Unfortunately, measured water-level changes generally were not available in the same areas where simulated water-level rises and declines occurred. To better evaluate the match between simulated and measured water-level changes, simulated changes also were compared with predevelopment to spring 2005 water-level change maps published by the Conservation and Survey Division (2005a). Generally, simulated water-level changes were consistent with mapped water-level changes. However, several areas of simulated water-level changes do not correspond to mapped water-level changes. Simulated rises in Pierce and Knox Counties, near the Niobrara River in Brown County, and in southern Custer and northern Dawson Counties, are not present on the map. In addition, mapped rises in Hooker, Thomas, McPherson, and Logan Counties are not simulated. Mapped declines in Custer, Holt, Buffalo, and Hall Counties are for the most part replicated in the simulation. However, it is important to note that the mapped water-level changes were created using a variety of years defined as "predevelopment" in different areas, so disparities may be present in a strict comparison between simulated 1940 through 2005 water-level changes and mapped water-level changes from "predevelopment."

The statistical differences between simulated and measured water-level changes for all of the time periods were averaged and weighted based on the number of calibration points selected in each time period. The weighting was done by multiplying the statistical difference for each period against the number of differences computed for that period, summing the weighted differences for all the periods, then dividing by the total number of differences for all periods. Therefore, periods with the most water-level changes more heavily affected 
Table 4. Statistical summary of calibration for selected time periods of the 1940 through 2005 simulation, Elkhorn and Loup River Basins, Nebraska.

[Tabled values are differences between simulated and measured water-level change, in feet; negative values indicate simulated declines smaller than measured declines, or simulated rises larger than measured rises; --, not calculated]

\begin{tabular}{|c|c|c|c|c|c|c|}
\hline Time period & $\begin{array}{c}\text { Number of } \\
\text { measurements }\end{array}$ & Mean difference & $\begin{array}{l}\text { Mean absolute } \\
\text { difference }\end{array}$ & $\begin{array}{c}\text { Root mean } \\
\text { squared } \\
\text { difference }\end{array}$ & $\begin{array}{l}\text { Maximum } \\
\text { difference }\end{array}$ & $\begin{array}{c}\text { Percentage of sites } \\
\text { with } 5 \text { feet of } \\
\text { difference or less }\end{array}$ \\
\hline $1945-1955$ & 207 & -1.57 & 2.60 & 3.89 & 20.8 & 86 \\
\hline 1955-1965 & 119 & -1.55 & 2.35 & 3.08 & 8.4 & 87 \\
\hline 1965-1975 & 158 & -.15 & 3.22 & 5.28 & 29.3 & 84 \\
\hline 1975-1985 & 411 & -2.33 & 2.56 & 4.20 & 28.3 & 88 \\
\hline 1995-2005 & 584 & .02 & 3.03 & 4.60 & 36.5 & 83 \\
\hline 1945-2005 & 42 & 1.19 & 5.04 & 6.39 & 17.7 & 60 \\
\hline Total measurements & 2,033 & -- & -- & -- & -- & -- \\
\hline Weighted average & -- & -.43 & 2.86 & 4.29 & -- & -- \\
\hline
\end{tabular}

model calibration because those periods more heavily affected the overall weighted-average statistics. The weighted-average mean difference was $-0.43 \mathrm{ft}$, the weighted-average mean absolute difference was $2.86 \mathrm{ft}$, and the weighted-average RMS difference was $4.29 \mathrm{ft}$ (table 4). Because the weightedaverage mean difference is relatively close to zero, simulated water-level changes were not greatly biased as compared to measured water-level changes. Positive mean difference values indicate that either measured water-level declines were smaller than simulated water-level declines or that measured water-level rises were larger than simulated water-level rises. Positive mean difference values also can occur when measured water levels are rising and simulated water levels are declining. Conversely, negative mean difference values indicate that either measured water-level declines were larger than simulated water-level declines or that measured water-level rises were smaller than simulated water-level rises. Negative mean difference values also can occur when measured water levels are declining and simulated water levels are rising.

In addition to measured and mapped water-level changes, simulated water levels also were compared with time-series hydrographs for some wells for the 1940 through 2005 period (fig. 25). Site locations were chosen primarily based on availability of long-term water-level measurements, in addition to spatial distribution, distance from surface-water features, and proximity of the well screen to the water table, though this was not always possible in areas with fewer wells. Sites also were selected in areas of contrasting simulated water-level change - two sites were chosen in areas where simulated water levels declined at least $5 \mathrm{ft}$ from 1940 through 2005 (wells 405226098390901, G; and 423641098580801, C), three sites were chosen in areas where simulated water levels rose at least $5 \mathrm{ft}$ from 1940 through 2005 (wells 410306099402701 , I; 413618099055801, E; and 415238097483700, D), and four sites were chosen in areas of little or no simulated water-level change from 1940 through 2005 (wells 404924098441801 , H; 411333098144601, F; 420204101200501, A; and 422930100321801, B).

Because the primary goal of the transient simulation calibration was to match simulated water-level changes with measured water-level changes while maintaining simulated base flow about the same as estimated base flow, the criterion used to assess the hydrograph match was symmetry of waterlevel change patterns with time. Simulated and measured water-level elevations are not expected to match exactly, but the difference between simulated and measured water-level elevations should remain constant with time, and the magnitude of water-level rises and declines should be similar.

In areas of simulated water-level decline, simulated water-level change patterns were similar to measured change patterns, particularly at well 423641098580801 (C), though the simulated decline from about 1965 to 1975 was larger than the measured decline. At well $404924098441801(\mathrm{H})$, the change patterns were comparable after about 1985, but the magnitudes of simulated rises and declines were less than those measured. However, the peaks and valleys exhibited by both hydrographs are in about the same place in time, which confirms that the simulation is demonstrating the correct trends at the correct times, even if the magnitudes are different. The same pattern was exhibited by hydrographs for well $405226098390901(\mathrm{G})$, where the trends of sections of the simulated and measured hydrographs match after about 1980, as do the peaks and valleys, but the magnitude of the simulated changes are less than the measured changes. Because these three wells were located in areas where most of the land is used for ground-water irrigated crops, these results indicate that the simulation is generally simulating the effects of ground-water irrigation through time. 

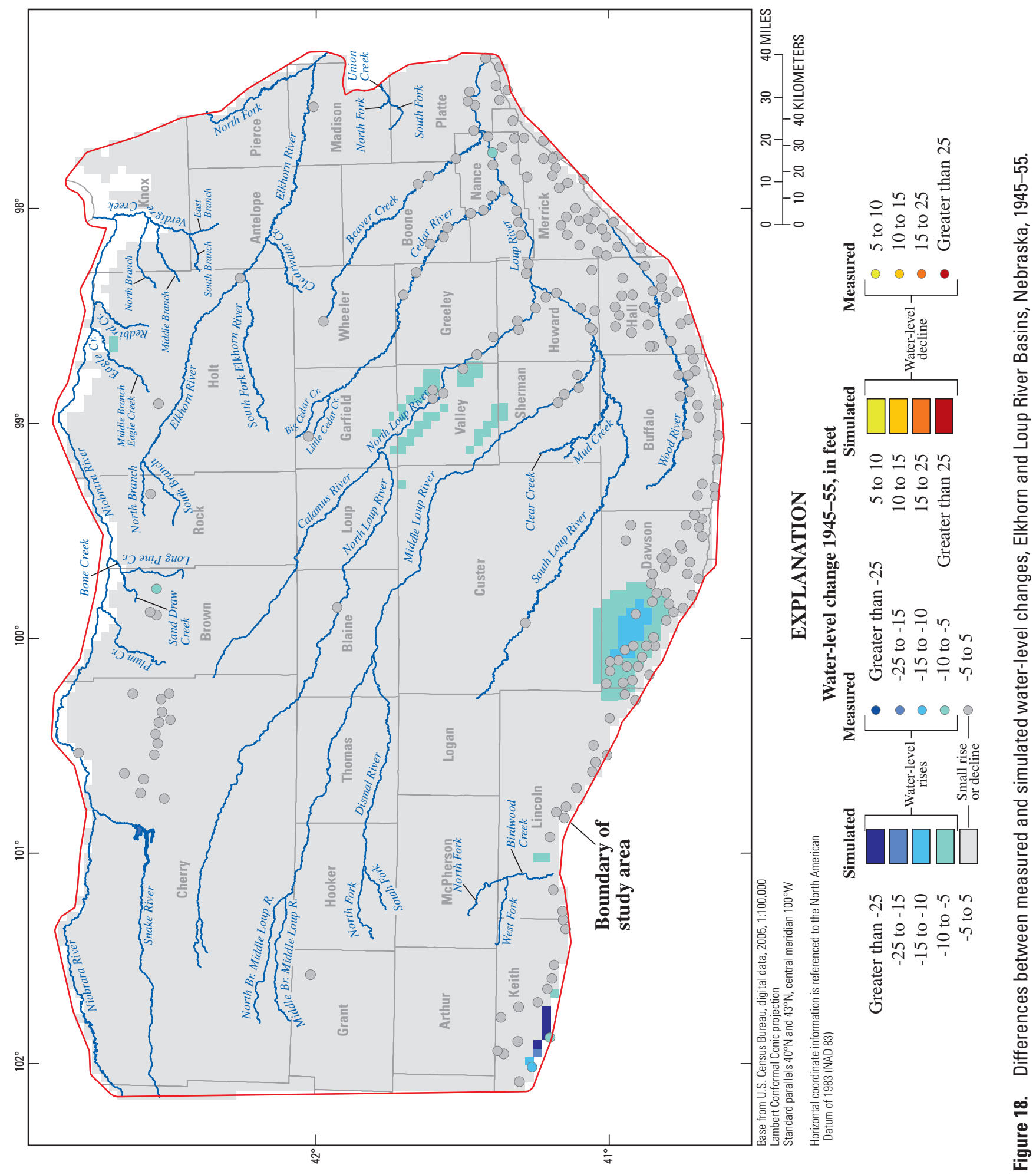


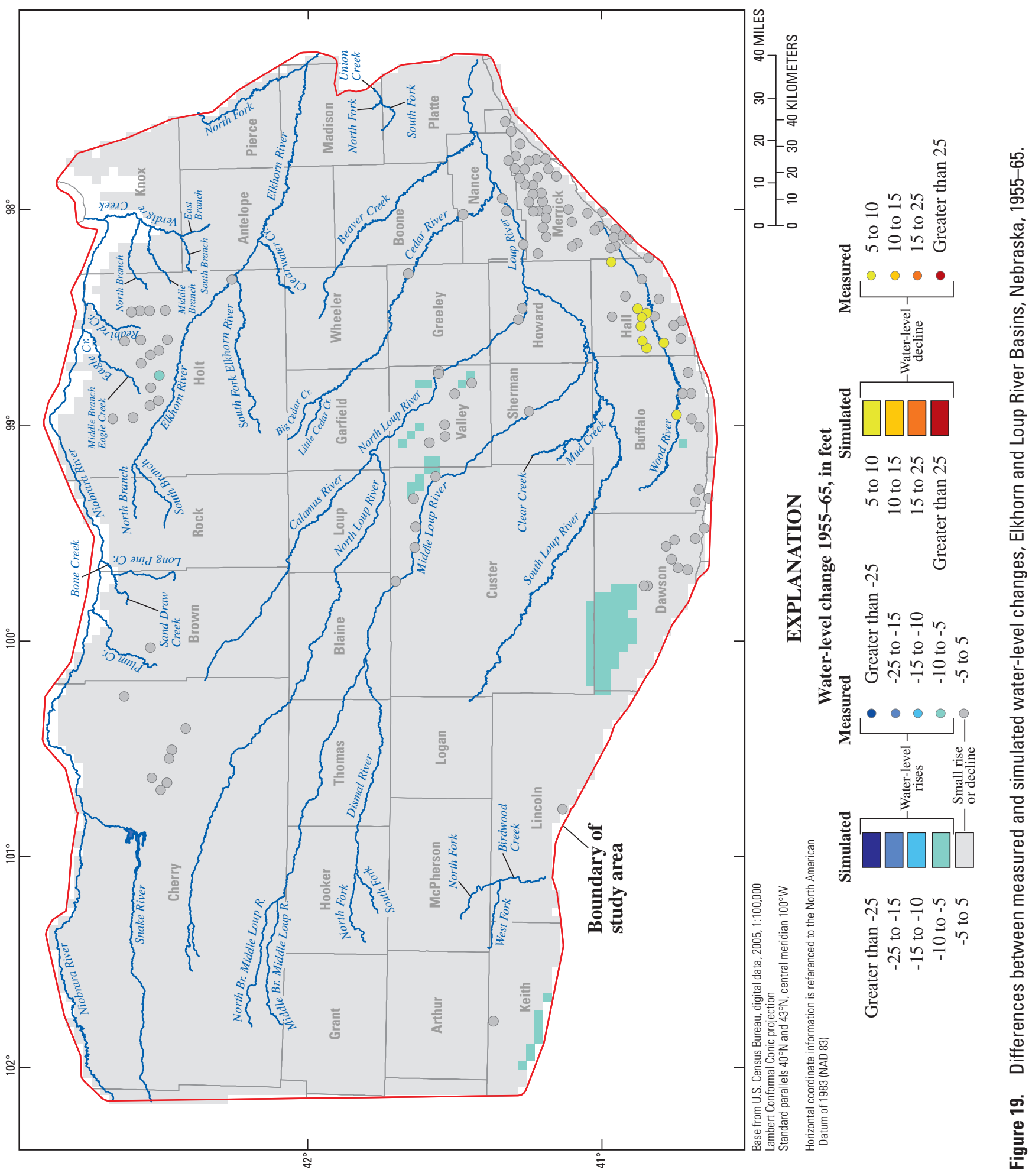




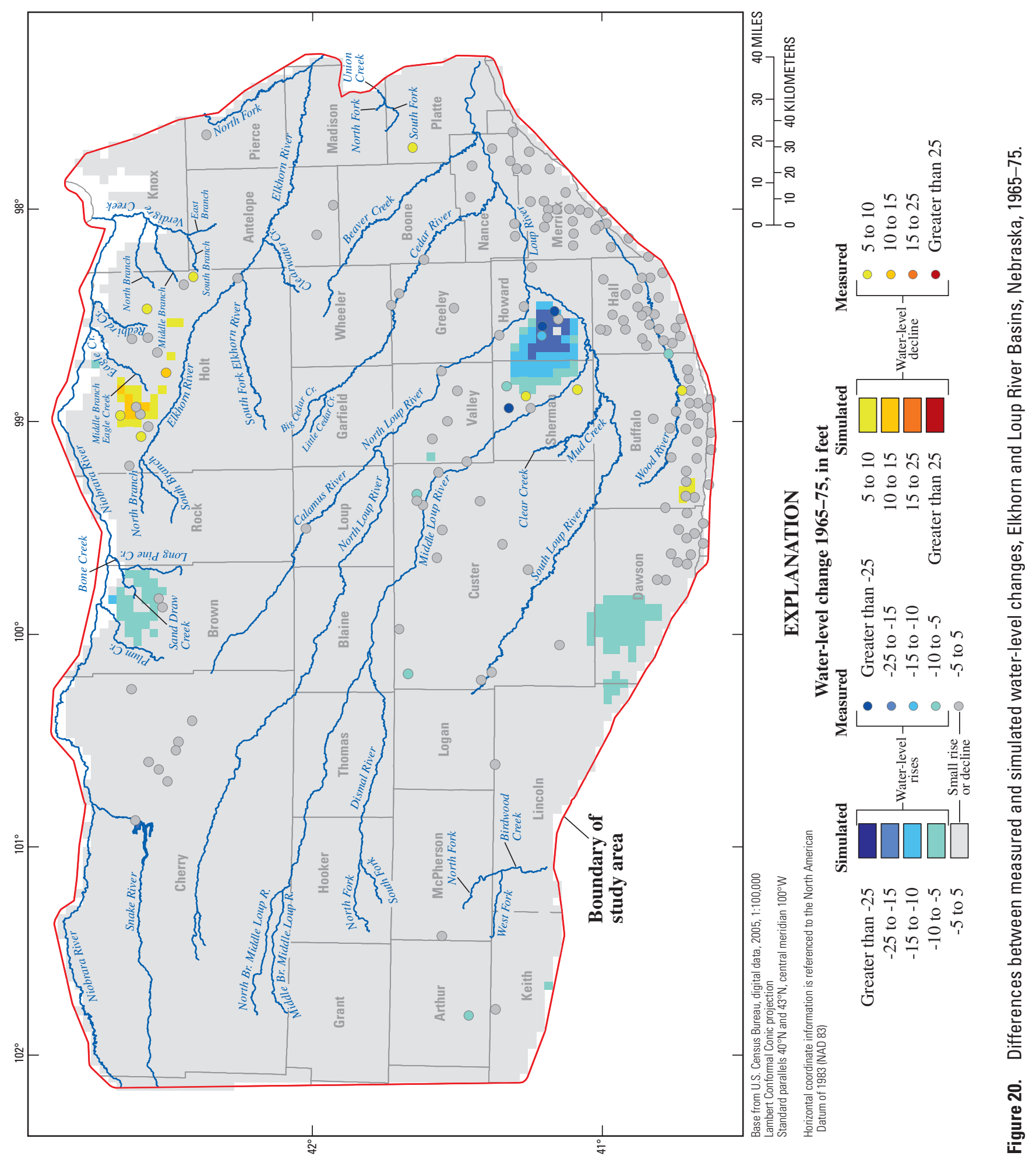




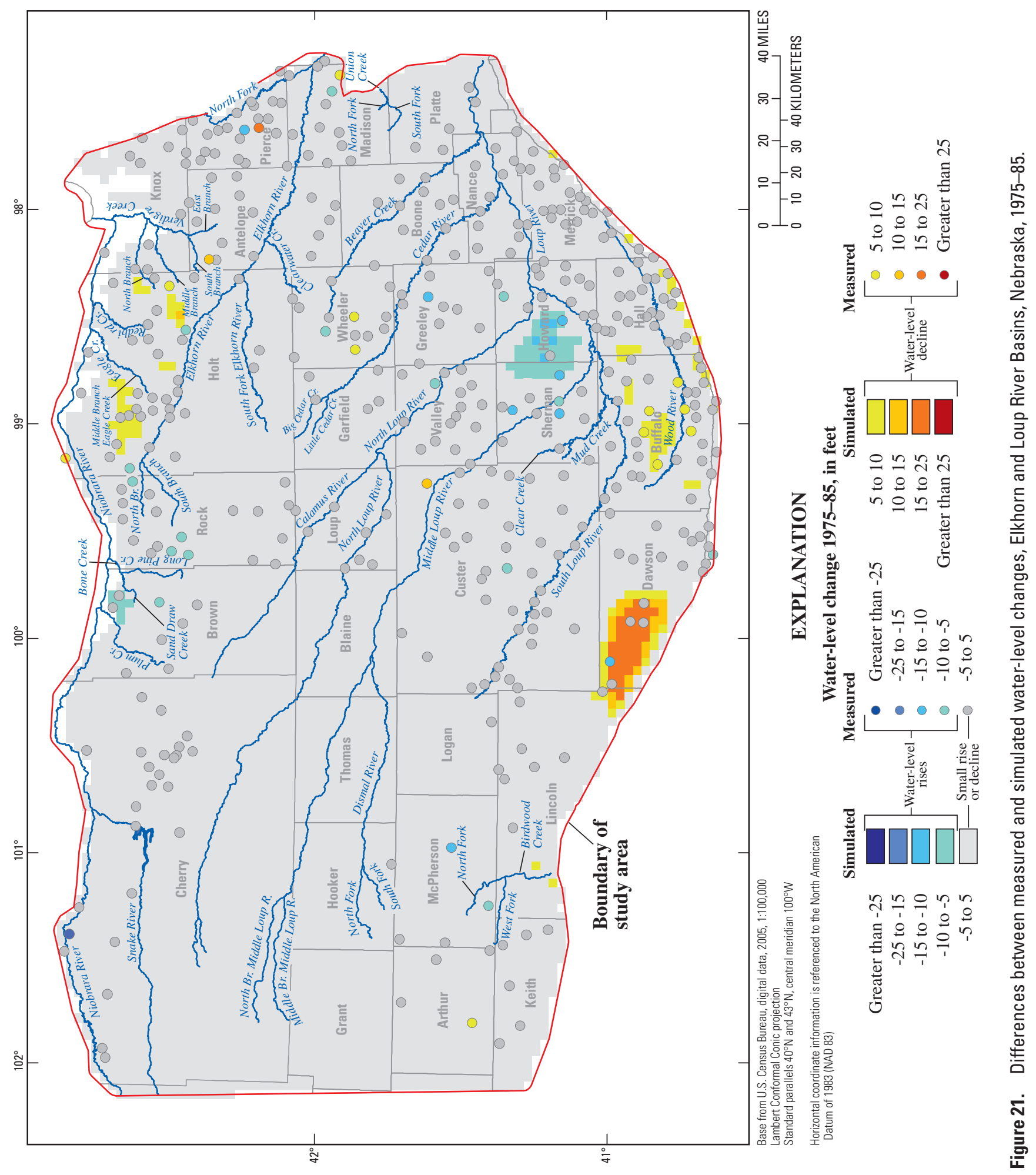




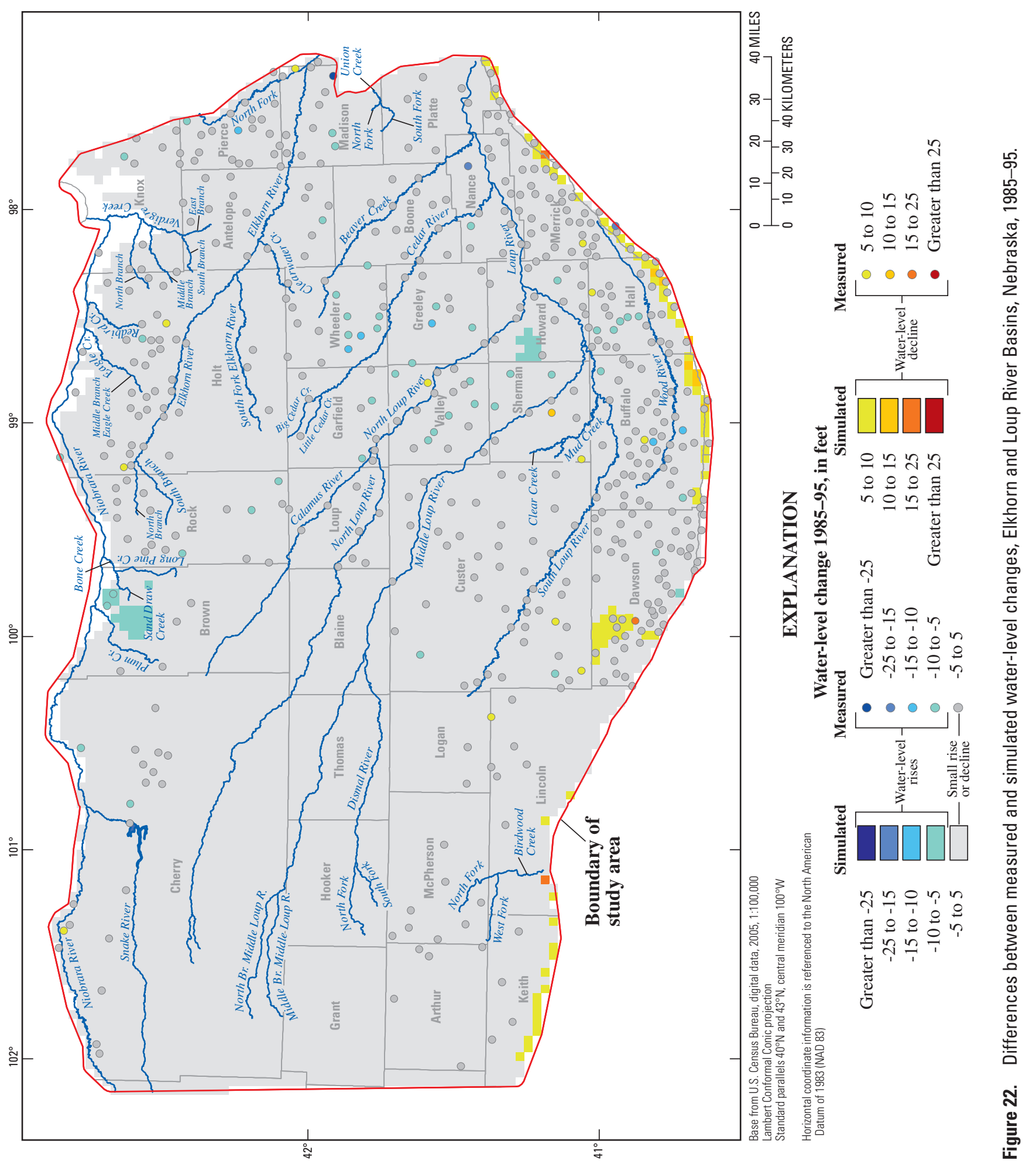



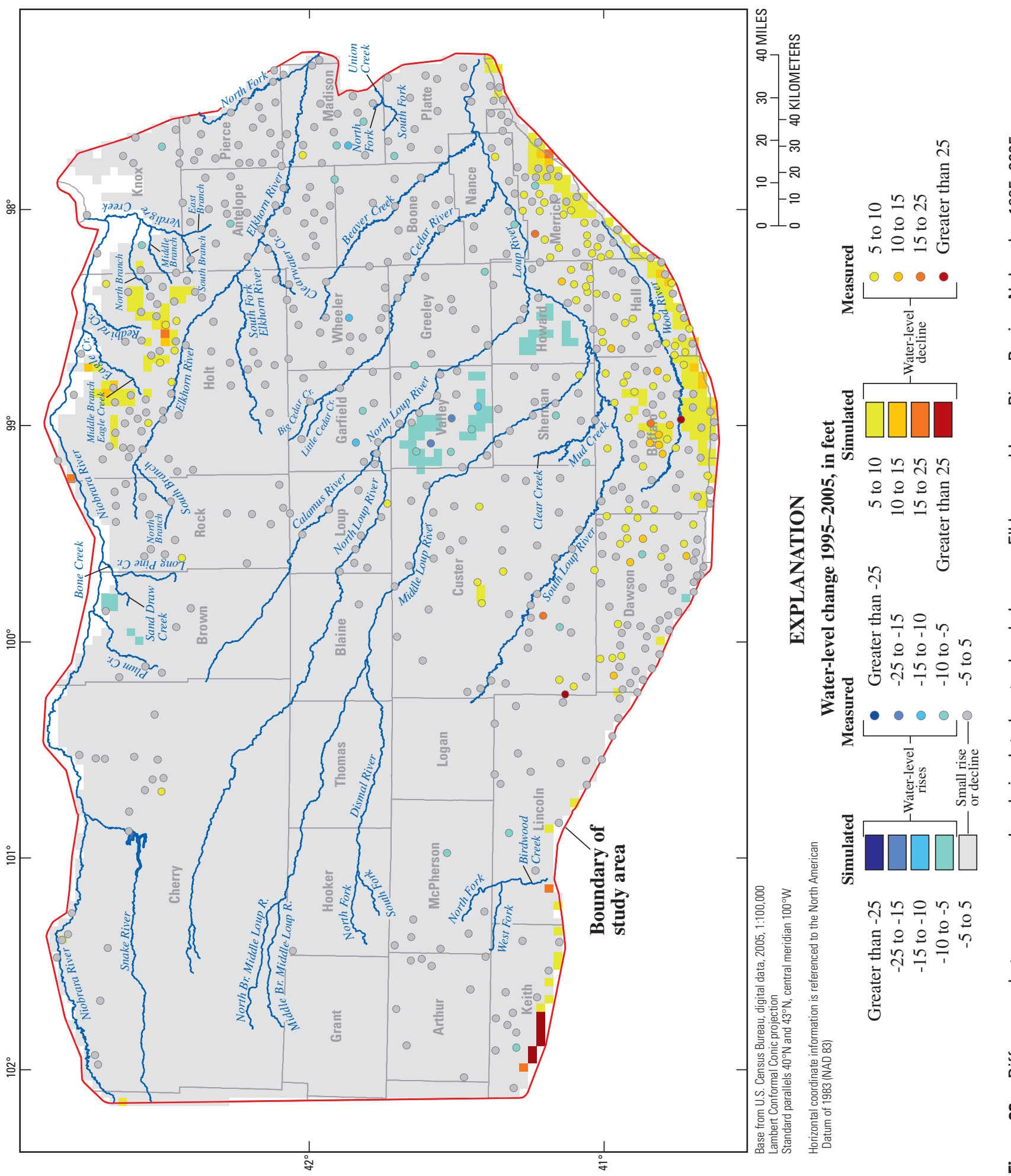

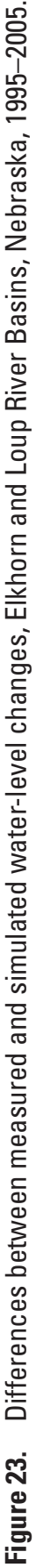



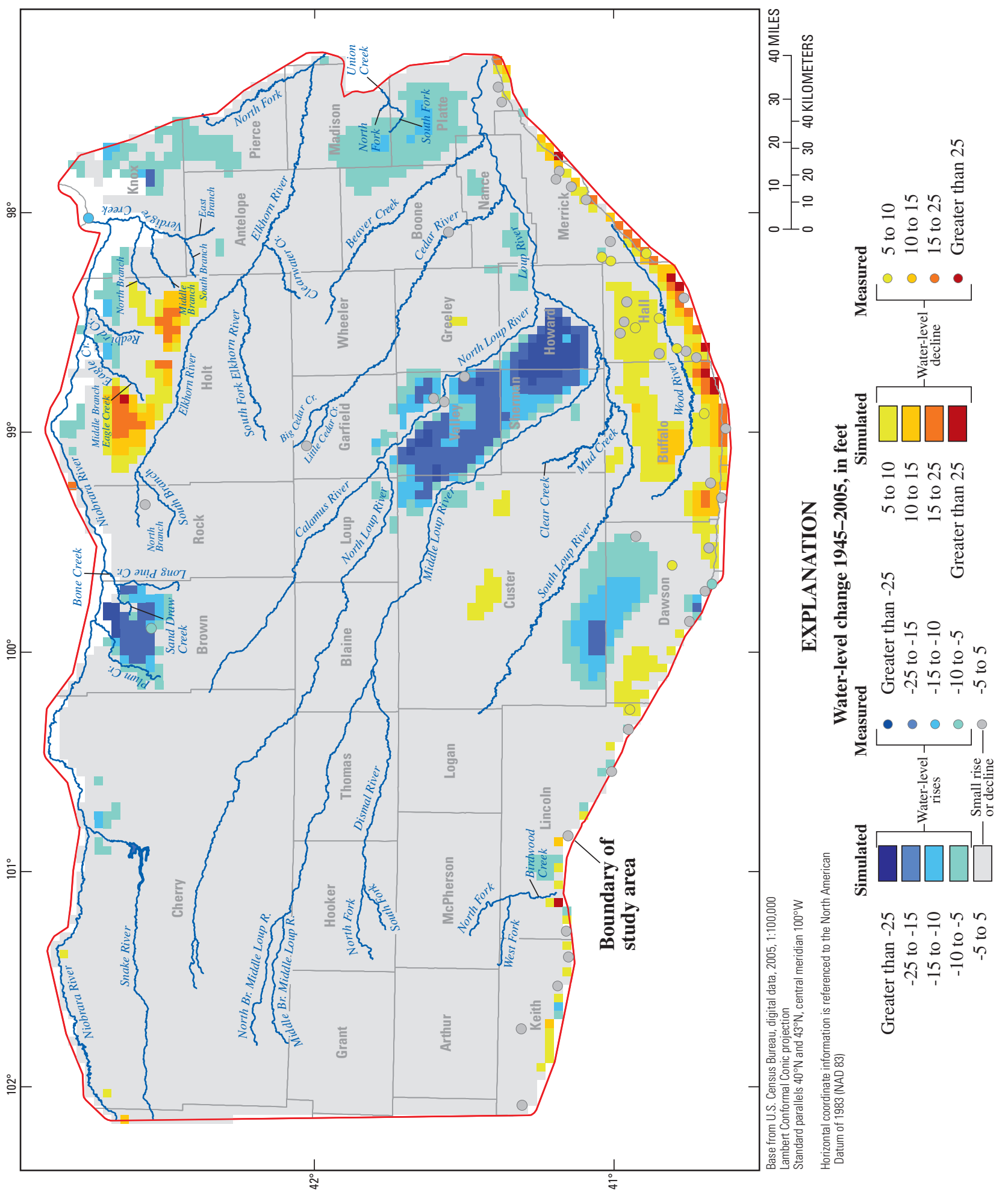

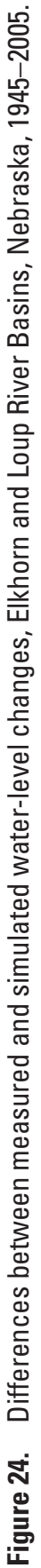

กิ

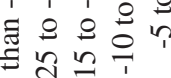
过 

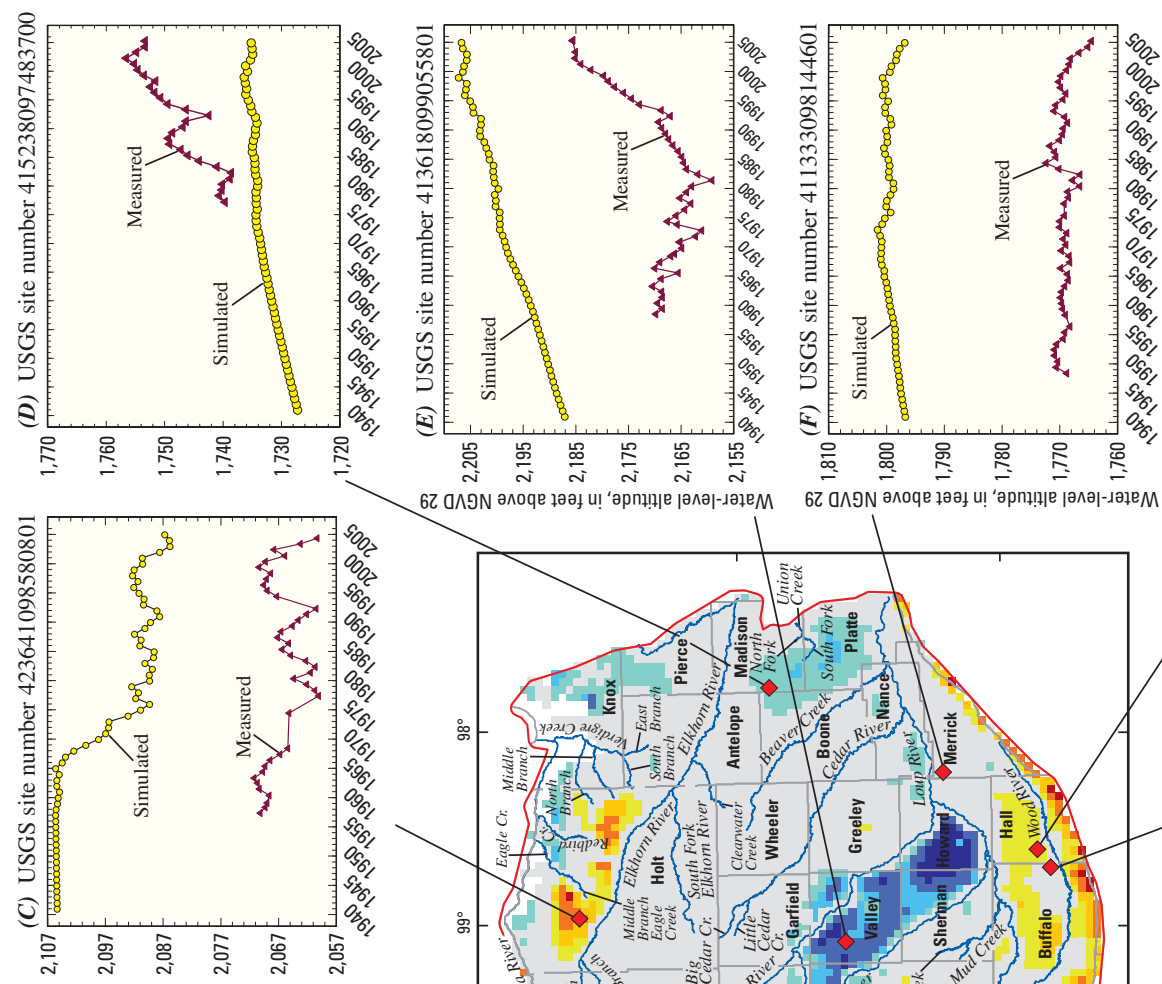

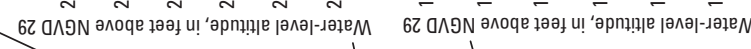
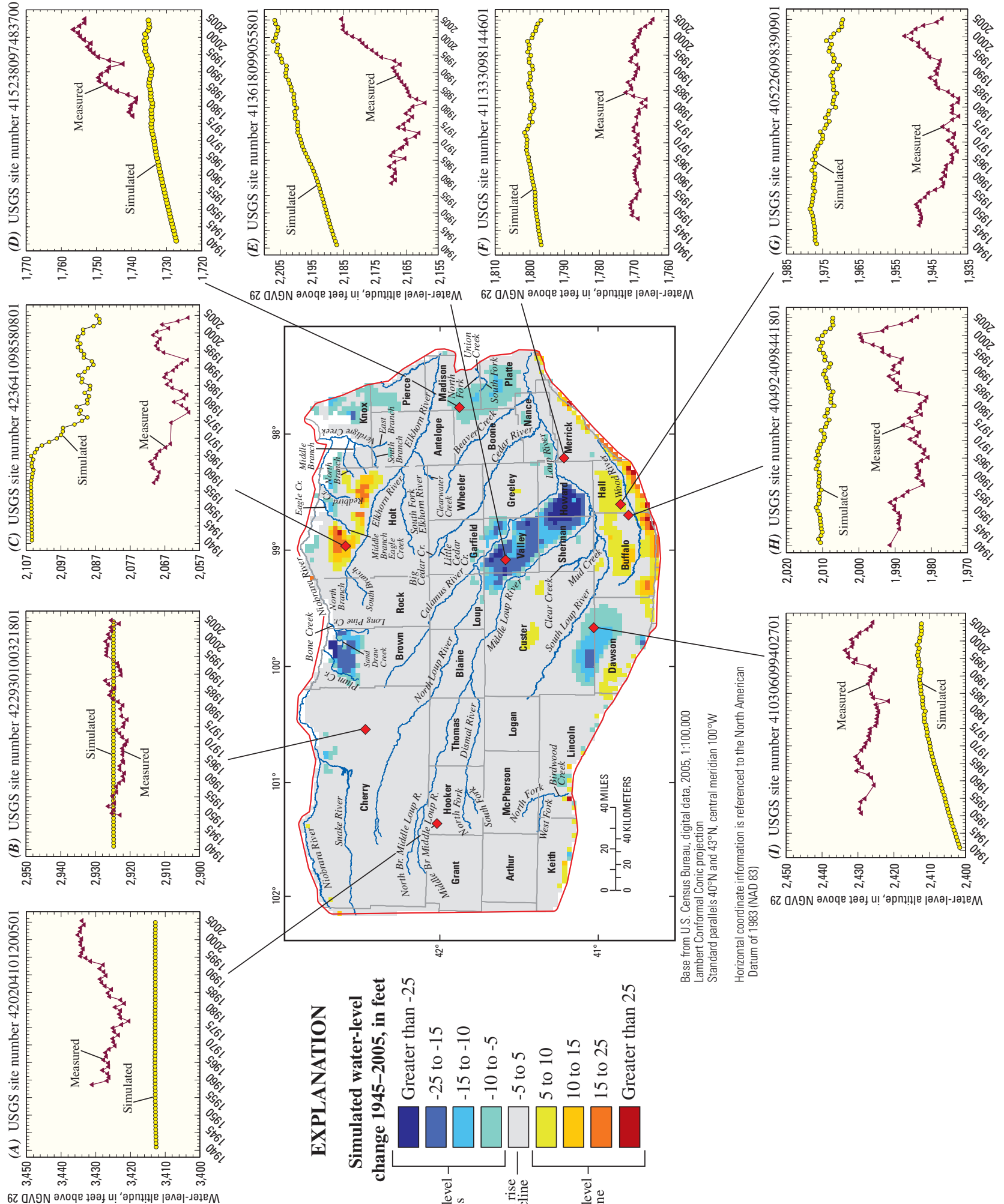

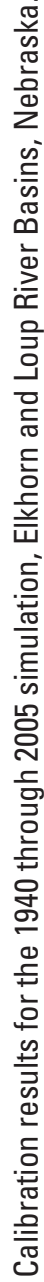
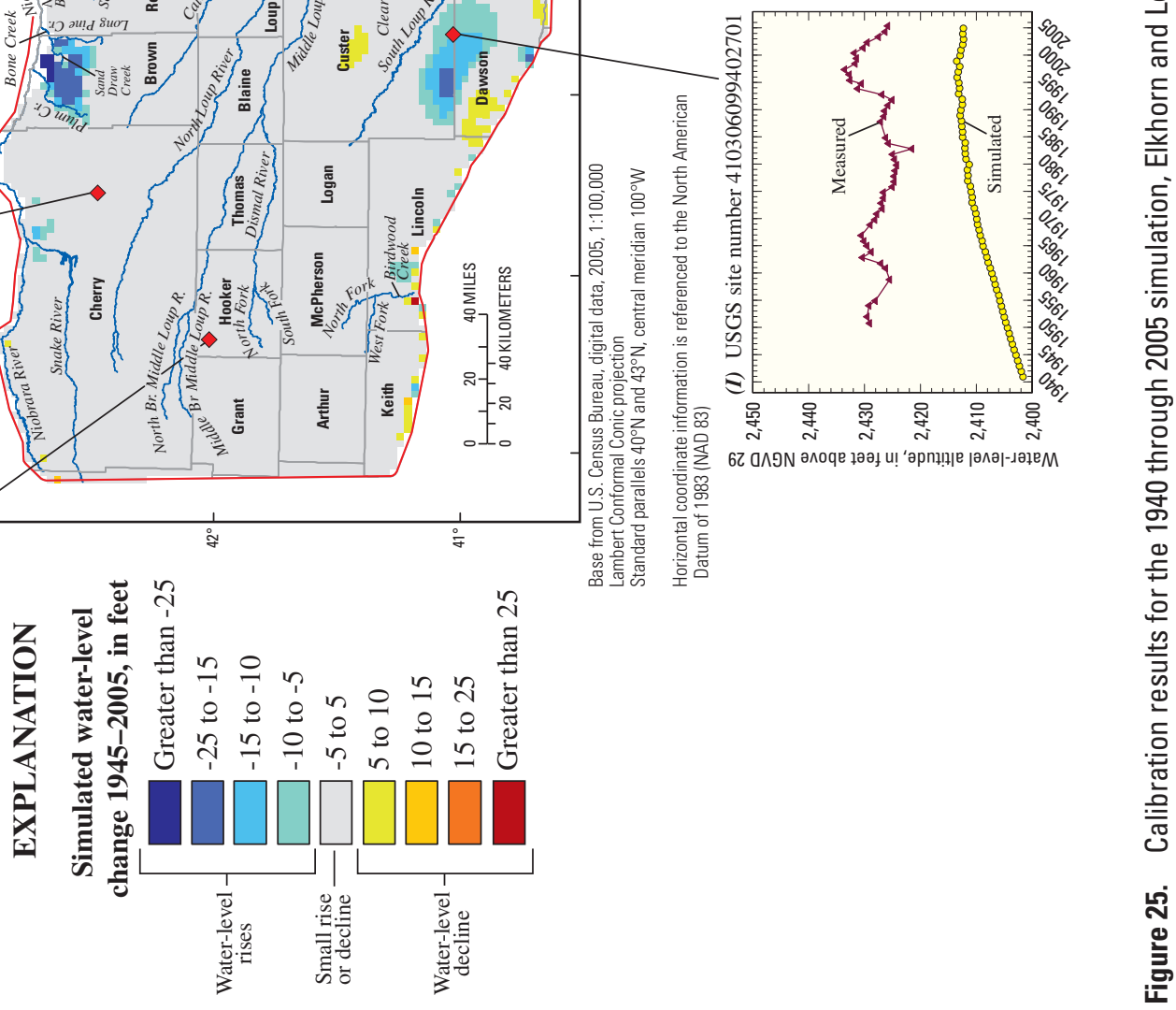
In areas of simulated water-level rise, the fit between simulated and measured change patterns was mixed. Simulated rises in southern Custer County were not present in the hydrograph for well 410306099402701 (I). Simulated waterlevel rises in Valley County generally were present in the hydrograph of well 413618099055801 (E) from the beginning to the end of record. From 1958 to 1982, however, measured water levels declined and simulated water levels rose, whereas after that time, the measured water levels increased by about the same amount as the simulated water levels increased during the 1940 through 2005 period. At well 415238097483700 (D), simulated and measured water levels rose, but simulated water levels had a smaller magnitude of rise and did not replicate two periods of measured declines.

In areas with small water-level changes, measured waterlevel fluctuations at two wells generally were replicated by the simulation (422930100321801, B; 411333098144601, F). However, the hydrograph for well 420204101200501 (A) shows that measured water levels fluctuated over a range of almost $15 \mathrm{ft}$, whereas simulated water levels did not change. The cause of this measured water-level rise is unclear; it does not occur in the hydrograph of well 422930100321801 (B), but based on only these few data, a conclusive determination cannot be made regarding regional water-level changes in undeveloped areas.

Simulated 2005 base flow was compared to estimated long-term base flow for 22 reaches based on streamflowgaging stations (table 2, fig. 9). ZONEBUDGET (Harbaugh, 1990) was used to retrieve simulated base flows from the simulation outputs for comparison, with the zones corresponding to the stream cells in between or upstream from streamflow-gaging stations (fig. 9) for which base-flow values were estimated (table 2). A detailed analysis of base-flow trends was beyond the scope of this study, but because the base-flow estimates were computed using the period of record data, and in many cases the period of record is several decades from the 1930 s to the 2000s, or at least a large part of that period, the base-flow estimates are regarded as indicative of long-term base flows. Therefore, the same approach to base-flow calibration was used for the simulated 2005 base flows as was used for the simulated 1940 base flows. If the simulated 2005 base flows were about the same as the "long-term" estimated base flows, the simulation was considered calibrated in respect to those base flows.

Simulated 2005 base flow at 45 percent (10 of the 22) of the USGS streamflow-gaging stations was within the range of estimated values (table 2). Simulated 2005 base flow at five stations was between 6 and 43 percent lower than the minimum estimated base flow. Simulated 2005 base flow was between 1 and 22 percent larger than the maximum estimated base flow at six stations, and about 85 percent larger than the maximum estimated base flow at one station (Mud Creek near Sweetwater). Streams with smaller 2005 base flow had the largest differences between the simulated and estimated base flow.
Averaged annually through the 1940 through 2005 simulation, approximately 68 percent of water entering the water-table aquifer was from recharge from precipitation (table 5). Other inflows of water were loss of stream base flow (10 percent), additional recharge applied to irrigated cropland areas ( 9 percent), canal-seepage recharge ( 5 percent), water leaving storage (3 percent), additional recharge applied to nonirrigated cropland areas ( 2 percent), and fixed water-level boundaries (1 percent). Ground-water discharge to stream base flow accounted for about one-half (53 percent) of the water leaving the water-table aquifer. Water also was lost from the water-table aquifer by evapotranspiration (19 percent), pumpage for irrigation (11 percent), fixed water-level boundaries (6 percent), base flow to drain boundaries (6 percent), water entering storage (4 percent), and pumpage for municipal use $(<1$ percent).

\section{Sensitivity Analysis}

\section{Methods}

Sensitivity of the calibrated simulation to changes in some of the simulation inputs was determined. The inputs tested primarily were calibration parameters or parameters for which uncertainty could have an important affect on the results. For example, most of the calibration of the pre-1940 simulation consisted of adjusting hydraulic conductivity and recharge, so these were included in sensitivity testing, as was recharge for the 1940 through 2005 simulation. Pumpage and specific yield were not calibration parameters for the 1940 through 2005 simulation, but pumpage affected how the inputs were adjusted to improve calibration, and uncertainty in specific yield might have affected the results, so these inputs also were tested for sensitivity.

The pre-1940 simulation and the 1940 through 2005 simulation were analyzed separately, and different inputs were investigated for different periods. The sensitivity analysis for each simulation consisted of uniformly increasing or decreasing a single simulation input and documenting how the input changes affected the comparison of simulated with measured water levels (pre-1940 simulation), simulated with measured water-level changes (1940 through 2005 simulation), and simulated 1940 and 2005 base flow with estimated long-term base flow. For the simulated 1940 water levels and simulated 1940 base flow, changes in streambed conductance, recharge from precipitation, hydraulic conductivity, and maximum evapotranspiration rate were investigated. For the simulated 1940 through 2005 water-level changes and simulated 2005 base flow, changes in specific yield, canal-seepage recharge, additional recharge applied to nonirrigated cropland areas, additional recharge applied to irrigated areas, and pumpage for irrigation were tested. 
Table 5. Average annual simulated ground-water budget for the 1940 through 2005 simulation, Elkhorn and Loup River Basins, Nebraska.

$[<$, less than; --, not applicable $]$

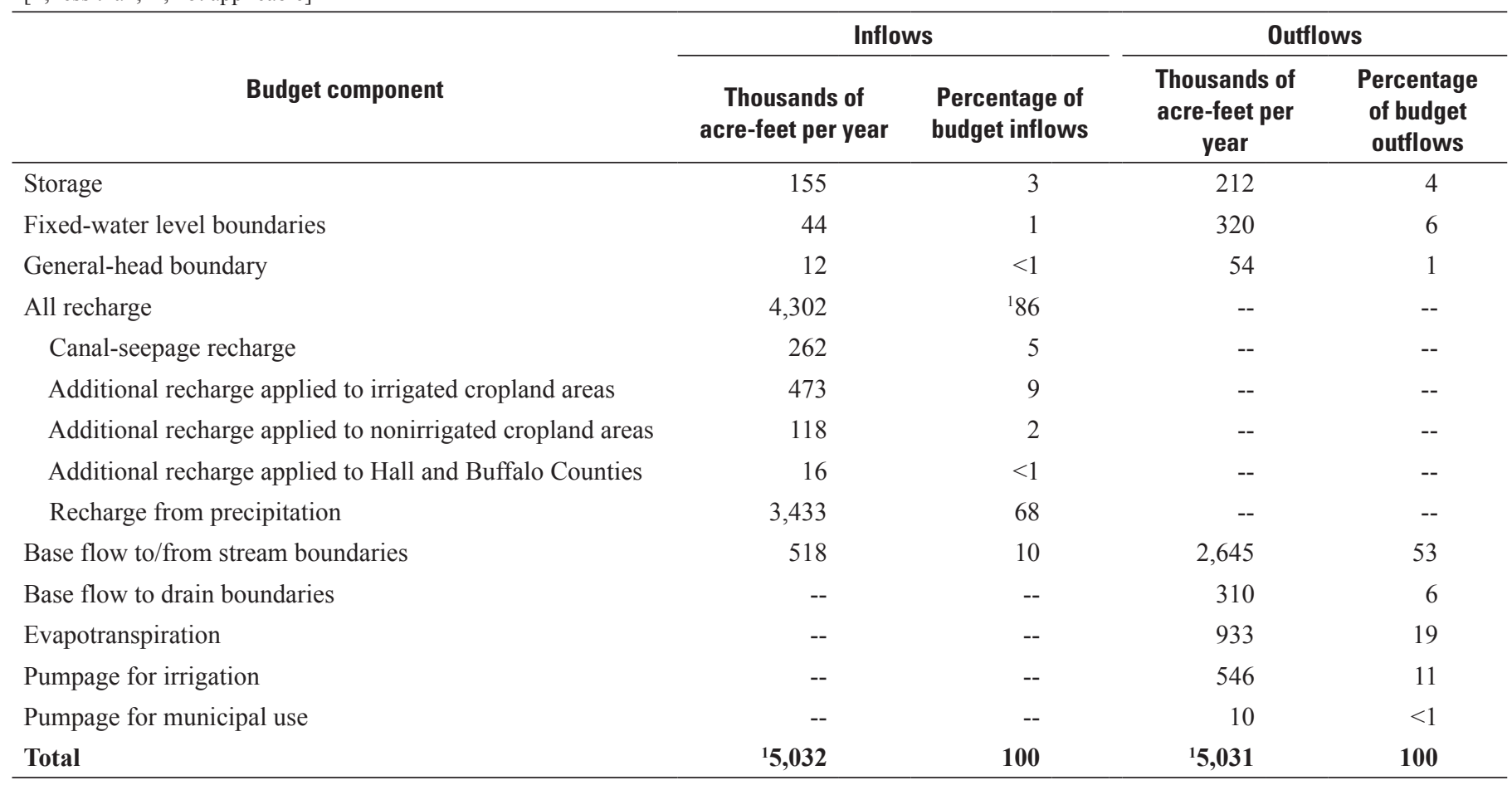

${ }^{1}$ Sum of components does not equal total because of rounding.

\section{Simulated 1940 Water Levels}

The sensitivity of the simulated 1940 water levels to input changes was indicated by changes in the mean difference, mean absolute difference, and root mean square difference between measured and simulated 1940 water levels (table 6, fig. 26). The analysis indicated that simulated water levels were most sensitive to hydraulic conductivity and recharge from precipitation, and that decreases in hydraulic conductivity and increases in recharge would have brought the mean difference between simulated and measured water levels closer to zero. However, those changes would have degraded the mean absolute and root mean squared differences between simulated and measured water levels, so these changes would not have improved the overall simulation calibration. The simulation was relatively insensitive to changes in the maximum evapotranspiration rate and streambed conductance, and those changes did not cause universal improvement among the three comparative statistics.

\section{Simulated 1940 Base Flow}

The sensitivity of simulated 1940 base flow to streambed conductance, recharge from precipitation, hydraulic conductivity, and maximum evapotranspiration rate was investigated for four streams: Calamus River near Burwell, Middle Loup River at Arcadia, North Loup River near St. Paul, and Elkhorn River at Neligh (fig. 9). ZONEBUDGET (Harbaugh, 1990) was used to retrieve simulated base flows from the simulation outputs for comparison, with the zones corresponding to the stream cells in between or upstream from streamflow-gaging stations (fig. 9) for which base-flow values were estimated (table 2). These four streams were selected because they represent a variety of settings within the study area. The Calamus River, a Sand Hills stream, drains a gently sloping terrain in the eastcentral area of the Sand Hills and has steady flow, as indicated by the small range from the minimum to maximum estimated base flow (table 2). The Middle Loup River is a Sand Hills stream with more variable flow (both smaller and larger base flow than the Calamus River) that drains the west-central area of the Sand Hills, and it has been affected by surface-water irrigation districts. The reach of the North Loup River for which sensitivity results were recorded is a non-Sand Hills stream that has been affected by surface-water irrigation districts, whereas the Elkhorn River is a non-Sand Hills stream in the eastern part of the study area that has not been affected by surface-water irrigation.

At these four streams, adjustments to recharge from precipitation rates yielded the largest changes to simulated baseflow values (table 7, fig. 27). Simulated base flow also was sensitive to changes in hydraulic conductivity, but relatively insensitive to changes in maximum evapotranspiration rate and streambed conductance. 


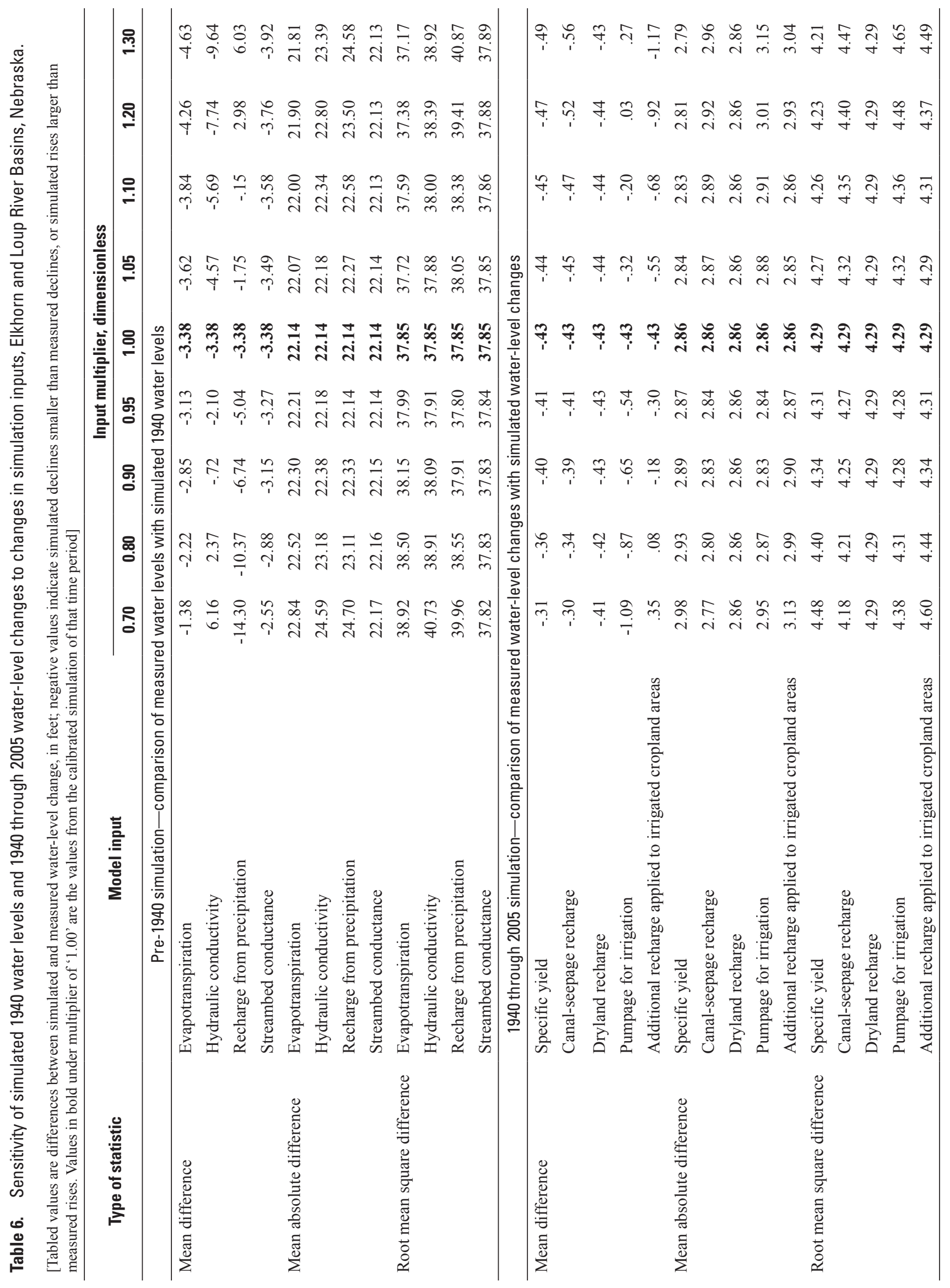




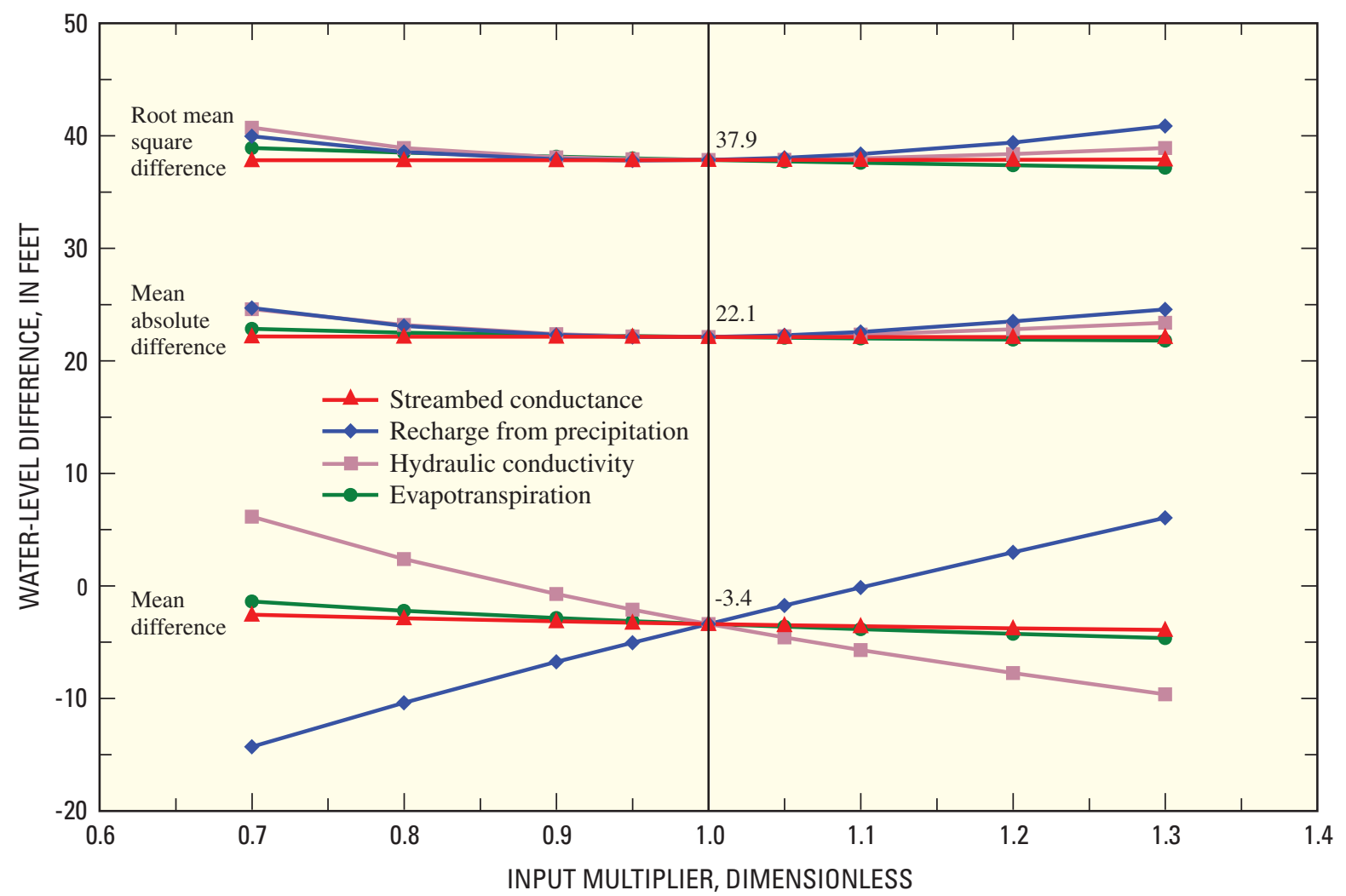

Figure 26. Sensitivity of simulated 1940 water levels to changes in simulation inputs, Elkhorn and Loup River Basins, Nebraska.

Changes to simulation inputs during the sensitivity analysis for 1940 base flow did not indicate that input modifications would improve simulated 1940 base flow. Simulated 1940 base flow for the Elkhorn River at Neligh was within the range of estimated long-term base-flow values for all tests (table 7). For the Calamus River near Burwell, simulated 1940 base flow was less than the estimated minimum base flow for the calibrated simulation. Increases to recharge from precipitation and hydraulic conductivity caused simulated 1940 base flow for the Calamus River near Burwell to increase to within the estimated range; however, increases to these inputs degraded calibration results for simulated water levels and therefore would not have improved overall simulation calibration. Similar for the Elkhorn River at Neligh, simulated 1940 base flows at the North Loup River near St. Paul were within the estimated range for all tests except for an increase in recharge from precipitation by 30 percent. For the Middle Loup River at Arcadia, a decrease of recharge by 30 percent caused simulated 1940 base flow to be lower than the estimated minimum base flow, whereas changes to all other simulation inputs resulted in simulated 1940 base flow values within the estimated range.

\section{Simulated 1940 through 2005 Water-Level Changes}

A sensitivity analysis was conducted for the 1940 through 2005 simulation, using the weighted-average mean difference, mean absolute difference, and root mean squared difference between simulated and measured water-level changes, totaling 2,033 measurements for all time periods (method of weighting described in the "Simulation Results" section of this report for the 1940 through 2005 simulation). Simulated water-level changes were most sensitive to changes in pumpage for irrigation and additional recharge applied to irrigated cropland areas, least sensitive to changes in specific yield and canal-seepage recharge, and relatively insensitive to changes in additional recharge applied to nonirrigated cropland areas (table 6, fig. 28).

Results did not indicate that increases or decreases in specific yield, irrigated-land recharge, and pumpage for irrigation would improve simulation calibration. However, averaged mean difference, averaged mean absolute difference, and averaged root mean squared difference were all at a minimum when canal-seepage recharge was decreased 30 percent, 


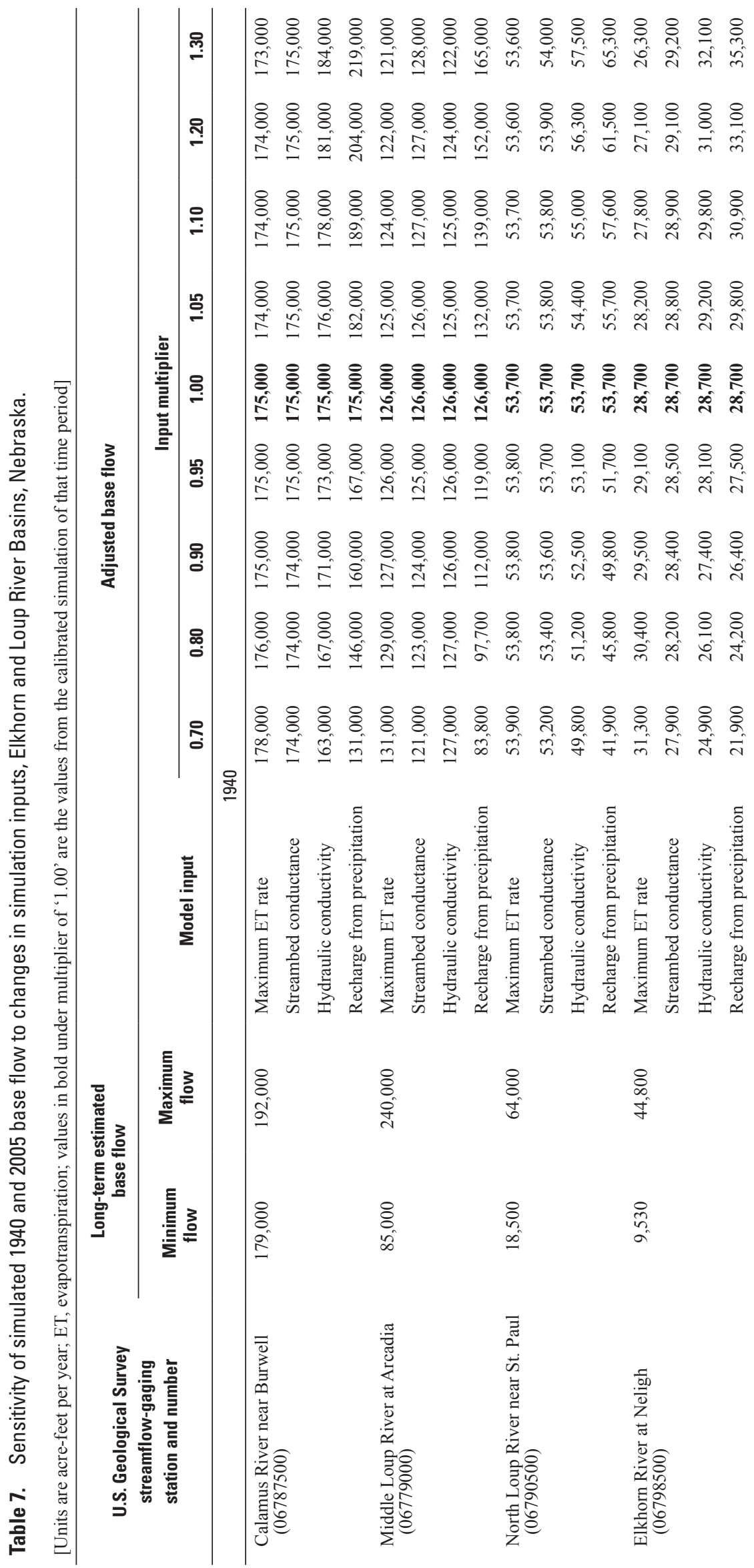




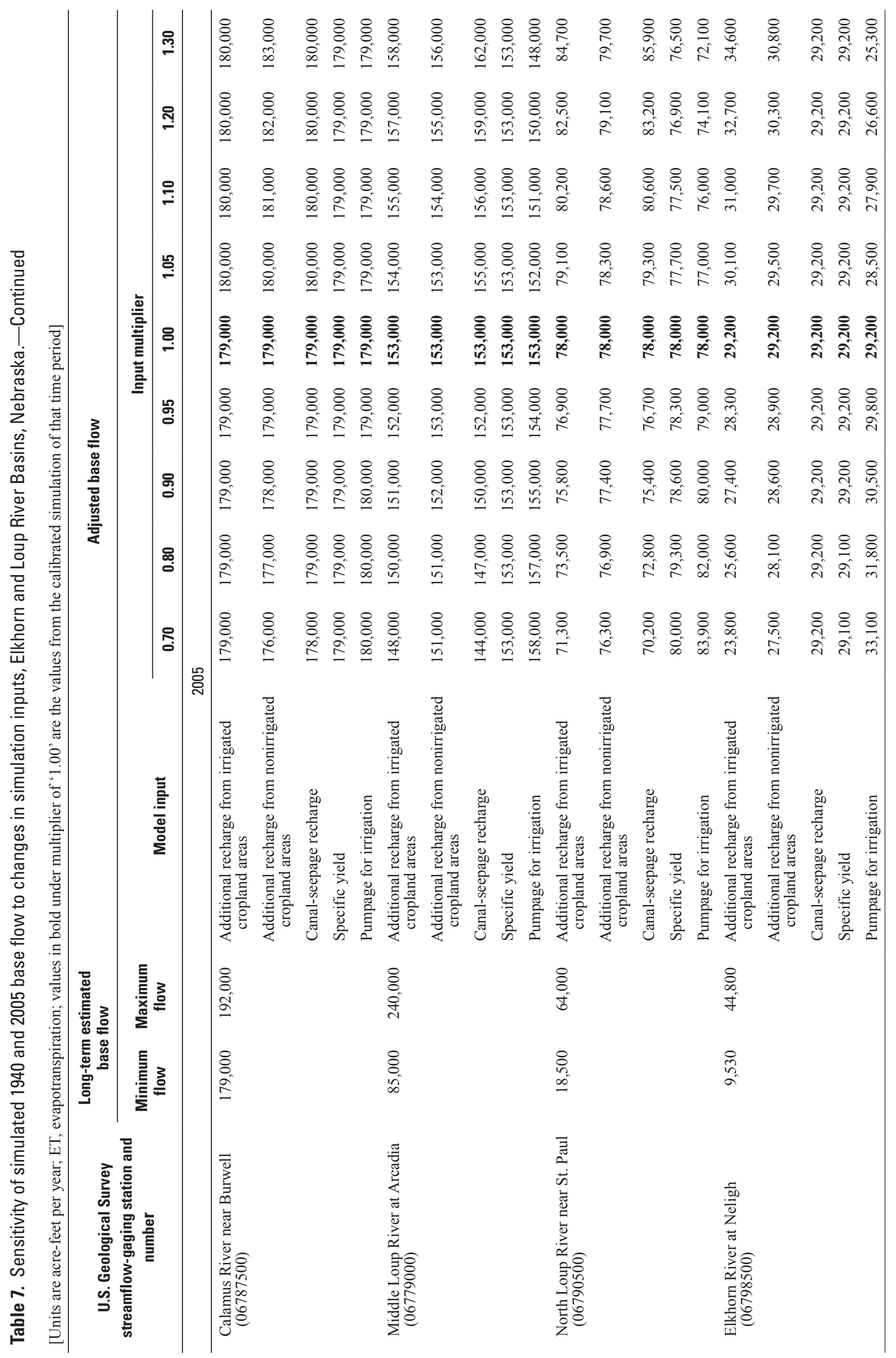



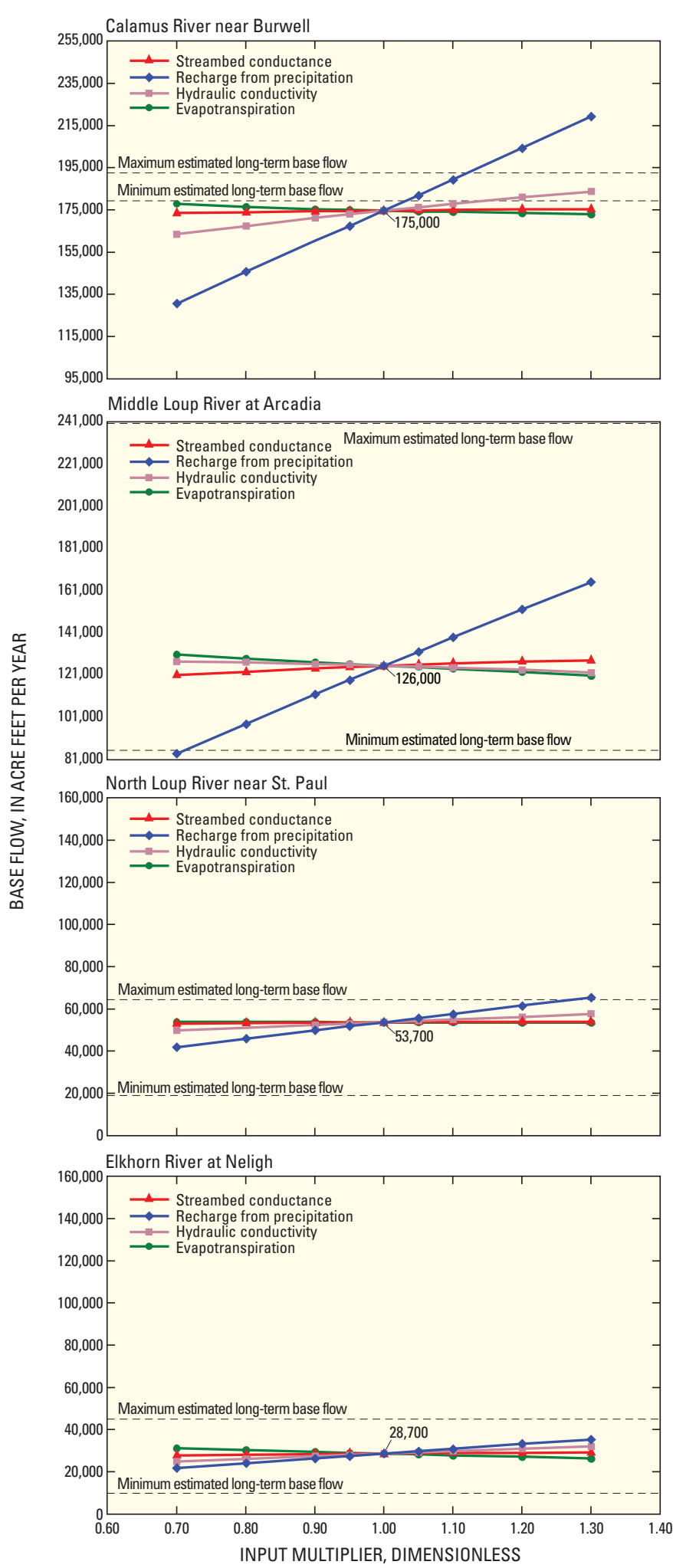

Figure 27. Sensitivity of the simulated 1940 base flow of selected streams to changes in simulation inputs, Elkhorn and Loup River Basins, Nebraska. indicating that a decrease in canal-seepage recharge would improve calibration. However, canal-seepage recharge was constrained with available data and was not adjusted during calibration; therefore it also was not adjusted after sensitivity analysis.

\section{Simulated 2005 Base Flow}

The sensitivity of simulated 2005 base flow to additional recharge applied to irrigated cropland areas, additional recharge applied to nonirrigated cropland areas, canal-seepage recharge, specific yield, and pumpage for irrigation was investigated for the same four streams that were used in the 1940 base-flow sensitivity analysis: Calamus River near Burwell, Middle Loup River at Arcadia, North Loup River near St. Paul, and Elkhorn River at Neligh (table 7, fig. 29). ZONEBUDGET (Harbaugh, 1990) was used to retrieve simulated base flows from the simulation outputs for comparison, with the zones corresponding to the reaches between or upstream from streamflow-gaging stations for which baseflow values were estimated (table 2). Simulated 2005 base flow was most sensitive to changes in additional recharge applied to irrigated cropland areas, canal-seepage recharge, and pumpage for irrigation.

For the Elkhorn and Middle Loup Rivers, simulated 2005 base flow was within the estimated base-flow range for the calibrated simulation and all changes to simulation inputs of up to 30 percent (fig. 29). Reductions greater than 5 percent to additional recharge applied to nonirrigated cropland areas and reductions greater than 20 percent to canal-seepage recharge caused simulated 2005 base flow for the Calamus River to be less than the minimum estimated base flow. Simulated 2005 base flow of the North Loup River was larger than the estimated range for the calibrated simulation and for all changes to inputs analyzed for sensitivity.

Reducing additional recharge applied to irrigated cropland areas caused North Loup River simulated 2005 base flow to improve but also degraded simulated water levels, which would not have improved overall simulation calibration. North Loup River simulated 2005 base flow decreased when pumpage for irrigation was increased, specific yield was increased, canal-seepage recharge was decreased, or additional recharge applied to irrigated cropland areas was decreased. However, increases to pumpage for irrigation degraded the mean absolute and root mean squared differences between simulated and measured water levels. Increases to specific yield caused only slight decreases in the North Loup River simulated 2005 base flow. Reductions in canal-seepage recharge caused North Loup River simulated 2005 base flow to decrease, but still not to less than the estimated maximum value. However, simulated canal-seepage recharge affecting this stream began after 1940 and increased greatly during the 1940 through 2005 period, and so could be considered to have increased by 100 percent; therefore, it was not surprising that a 30 percent reduction failed to reduce it to within the estimated range. In addition, canal-seepage recharge was relatively well 


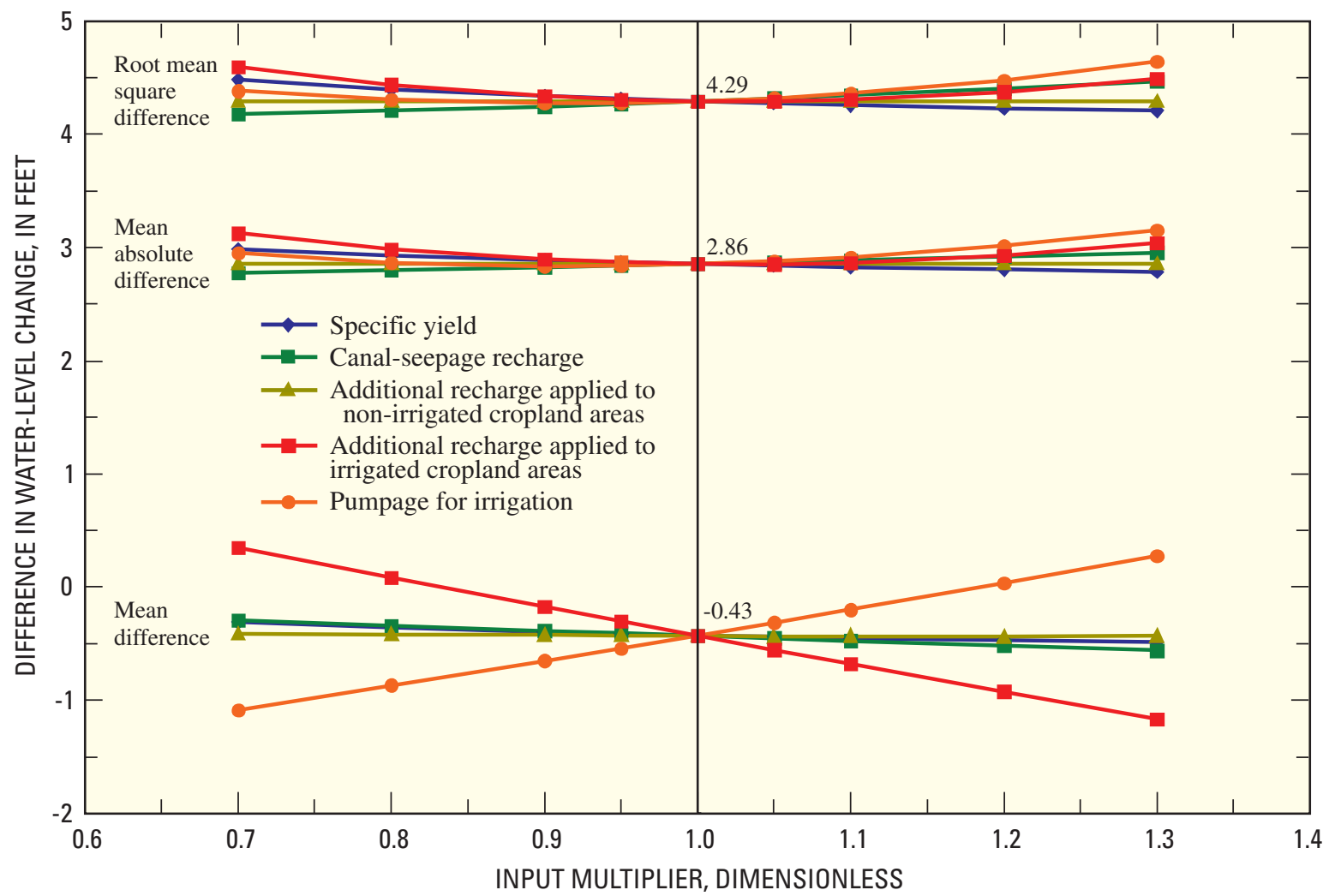

Figure 28. Sensitivity of the simulated 1940 through 2005 water-level changes to changes in simulation inputs, Elkhorn and Loup River Basins, Nebraska. (Results are a weighted average combining seven separate time periods.)

constrained for most surface-water irrigation districts, and thus was not a calibration parameter.

\section{Effects of Ground-Water Irrigation on Base Flow}

The calibrated simulation was used for two different types of analyses designed to provide information about the effects of ground-water irrigation on base flow, upon which long-term management decisions could be based. Both analyses used simulations of hypothetical future scenarios. The first analysis determined the effects of ground-water irrigation on simulated base flow for the calibrated 1940 through 2005 simulation and predicted future effects with a 2006 through 2045 simulation. Results of this analysis are described in the "Difference in Simulated Base Flow Caused by Ground-Water Irrigation" section of this report. The length of the future period in the hypothetical scenario used for this analysis was not tied to a specific rule or guideline; the desired result was to evaluate the effects of ground-water irrigation on simulated base flow for an extended period in the future. Therefore, 40 years was selected because it was thought to be an adequate period of time to analyze system responses demonstrated by comparing base flows for simulations with and without inputs related to ground-water irrigation.

The section entitled "Base-flow Depletion Percentage for a 50-year Period" describes a hypothetical scenario in which the simulation was used to create maps showing the simulated response of streams to pumping one additional theoretical well for 50 years. In other words, the map shows how much base-flow depletion would occur at each grid cell from various nearby streams, from pumping one new well from 2006 through 2055. This analysis was conducted because maps of percentage base-flow depletion for a specified period have been the basis for management boundaries in Nebraska (Nebraska Department of Natural Resources, 2005b, 2006).

\section{Assumptions and Limitations}

The analyses described in this report for determining the effects of ground-water irrigation on base flow are based on simulations that predict hypothetical future conditions, either 40 or 50 years beyond 2005. Future climate and land-use conditions in these simulations were estimated with the following assumptions. Future pumpage and additional recharge applied to irrigated cropland areas were estimated using 2005 land-use data, which assumes that in the future neither more nor less land would be used for growing crops. The average climatic 


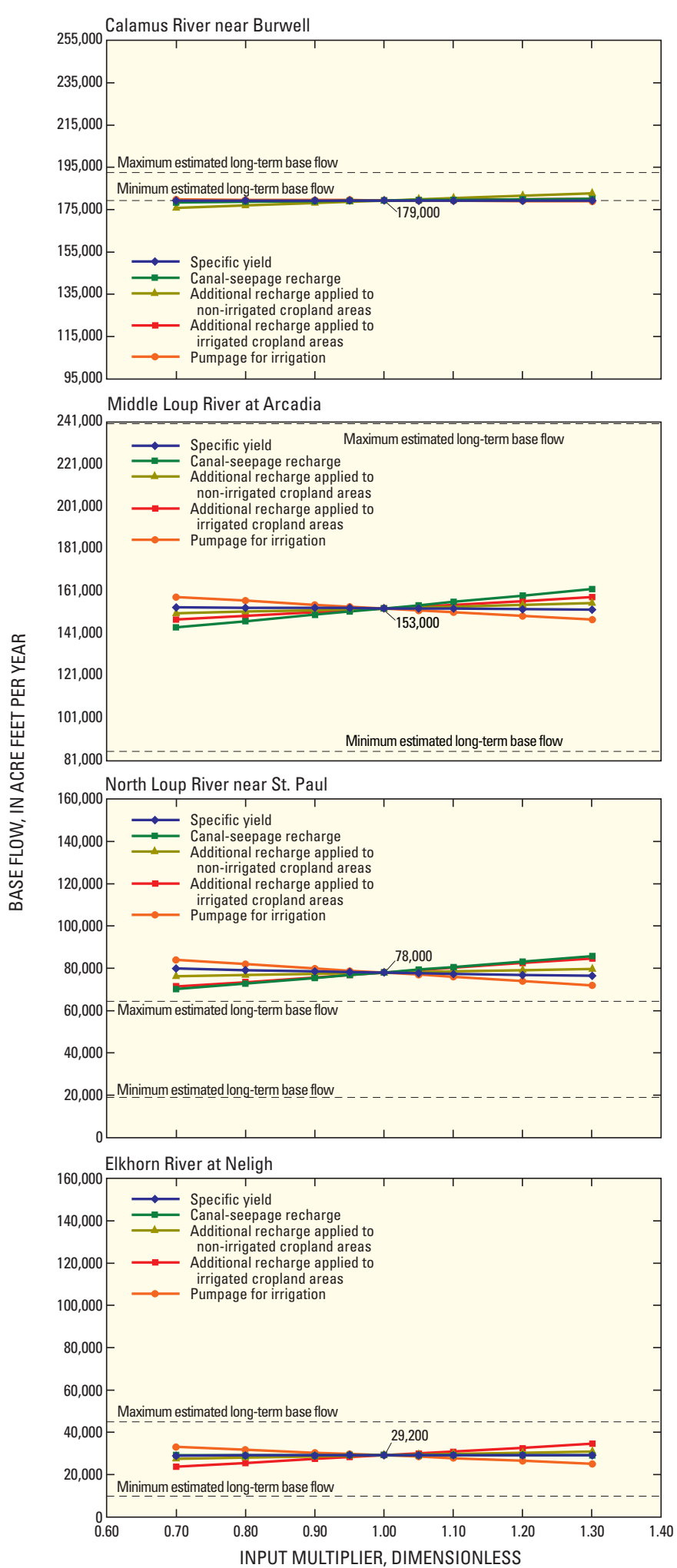

Figure 29. Sensitivity of the 2005 simulated base flow of selected streams to changes in simulation inputs, Elkhorn and Loup River Basins, Nebraska. conditions for 1940 through 2005 also were used to estimate future pumpage for irrigation for the analysis simulations, and these average conditions were held constant throughout the analysis period. Although climate and land use are unlikely to remain the same for the next 40 or 50 years, future conditions are unknown. Therefore, either the 2005 conditions, in the case of cropland distribution, or average conditions, as in the case of climate, were used to represent future conditions.

The accuracy of the analyses described in this report is dependent on the assumption that the Elkhorn-Loup Model is a reasonably calibrated representation of the ground-water system and important processes affecting that system. This is thought to be true because the 1940 through 2005 simulation produced simulated water-level changes that were comparable to measured water-level changes while maintaining a reasonable match of simulated base flows to estimated long-term base flows. However, it was noted that the accuracy of the 1940 through 2005 simulation was dependent on simulated pumpage. Simulated pumpage, in turn, is dependent on other factors, as described in the description of simulation inputs for the 1940 through 2005 simulation, and in the "Simulation Limitations" section of this report. Though simulated pumpage is thought to be approximately correct, uncertainty in the simulated pumpage cannot be quantified; therefore, uncertainty in the analysis results also cannot be quantified. As with analyzing the system using analytical equations or any other method, the results of these analyses are tools to diagnose important system behavior, and should not be regarded as absolute or precise predictions of the future state of system components.

\section{Difference in Simulated Base Flow Caused by Ground-Water Irrigation}

State and regional water-resources managers have concerns about the long-term availability of the ground-water resources in the Elkhorn-Loup Model area, as well as the sustainability of base flow to streams as it constitutes a large part of flow of these streams. Stream systems constantly are changing in response to changes in climate, the ground-water system, and anthropogenic changes, so it can be difficult to assess what part of these base-flow changes were caused by ground-water irrigation as opposed to other factors.

\section{Approach}

The calibrated Elkhorn-Loup Model simulating 1940 and 2005 base flow suitably matched estimated long-term base flow, and the simulation included inputs specific to pumpage for irrigation and additional recharge applied to irrigated cropland areas. Therefore, the effects of ground-water irrigation on base flows were assessed by comparing base flows of the simulation representing current (2005) conditions with base flows of a simulation where pumpage for irrigation was removed and additional recharge applied to ground-water irrigated cropland areas was changed to the recharge rate applied 
to nonirrigated cropland areas. Future effects of ground-water irrigation on base flows were assessed by comparing a future simulation that included pumpage for irrigation and supplemental recharge to a future simulation that did not include pumpage for irrigation or the additional recharge above nonirrigated cropland area recharge rates.

To assess the effects of ground-water irrigation on simulated base flow, the calibrated 1940 through 2005 simulation (1940 through 2005 baseline simulation) was compared to the 1940 through 2005 simulation with no ground-water irrigation (NGWI simulation). The NGWI simulation included all of the same inputs as the 1940 through 2005 baseline simulation, but pumpage for irrigation was removed, and the additional recharge applied to ground-water irrigated cropland areas in the 1940 through 2005 baseline simulation (3.5 in/yr more than recharge from precipitation applied to unbroken lands) was reduced to the amount of additional recharge applied to nonirrigated cropland areas ( $0.5 \mathrm{in} / \mathrm{yr}$ more than recharge from precipitation applied to unbroken lands). Calibrated irrigatedland recharge was maintained for all surface-water irrigated crops. Simulated base flows from the 1940 through 2005 baseline simulation were compared against those from the 1940 through 2005 NGWI simulation. The difference in the two base-flow results represents the simulated effects of groundwater irrigation on 1940 through 2005 base flow.

This method was repeated for 2006 through 2045. The 2006 through 2045 baseline simulation was assigned the simulated baseline 2005 water levels as starting water levels, and other inputs were held constant for the remainder of the simulation period. Recharge was the same as that used in the baseline simulation for 2005, and pumpage for irrigation was based on 2005 land-use data and average 1940 through 2005 climatic conditions. Similarly, a second NGWI simulation was created, and was assigned the simulated NGWI 2005 water levels as starting water levels, and again, other inputs were held constant for the remainder of the simulation period. Recharge and pumpage (both for irrigation and municipal use) were the same as those used in the NGWI simulation for 2005. Simulated base flows from the 2006 through 2045 baseline simulation were compared with those from the 2006 through 2045 NGWI simulation. The difference in the two predictions represents the simulated effects of ground-water irrigation on simulated 2006 through 2045 base flow.

\section{Results for 1940 through 2005}

ZONEBUDGET (Harbaugh, 1990) was used to retrieve simulated base flows from the simulation outputs, by river reaches grouped into zones (fig. 30). The zones used were the upper Elkhorn River, from the upper perennial reach down to and including the South Fork of the Elkhorn River (zone 1); the lower Elkhorn River, from the end of zone 1 downstream to the eastern end of the ELM area, including the North Fork of the Elkhorn River (zone 2); the North Loup River, from the upper perennial reach down to the confluence with the Middle Loup River (zone 3); the Middle Loup River, from the upper perennial reach down to the confluence with the South Loup River (zone 4); the South Loup River from the upper perennial reach down to the confluence with the Middle Loup River (zone 5); and the downstream Loup River area, from the lower end of zones 3 and 4, downstream to the eastern end of the ELM area (zone 6) (fig. 30). The cumulative effects of ground-water irrigation on simulated 1940 through 2005 base flow are shown in figure 31.

The cumulative effects on simulated base flow followed a similar trend for all zones (fig. 31); effects were minimal before 1970, and increased steadily after 1970. This seems reasonable because before 1970 , most ground-water irrigation was limited to areas near the Platte River, whereas groundwater irrigation became much more common throughout the interior of the study area after around 1970. The cumulative effect in 2005 was largest (about 695,000 acre-ft) for the Loup River downstream area (zone 6), though this is not surprising because streams in that zone probably are in close proximity to more ground-water irrigated acres than streams in other zones. The cumulative effect in 2005 was smallest for the Upper Elkhorn (zone 1), at about 438,000 acre-ft. Because inputs related to ground-water irrigation were removed from the entire ELM area at once, these analysis results do not indicate the location of the ground-water irrigation that affected each stream zone. The sum of the cumulative 1940 through 2005 effects for the Elkhorn River zones ( 1 and 2) was 888,000 acre-feet, whereas the sum of the cumulative 1940 through 2005 effects for the Loup River zones (3 through 6) was 2,273,000 acre-feet.

The annual rate of ground-water irrigation effects on simulated base flow for the various basins, reflecting in part the effects of climate variability from 1940 through 2005 on pumpage for irrigation, are shown in figure 32. As pumpage for irrigation increased or decreased each year (fig. 16) in response to the amount of growing season effective precipitation, the effects on simulated base flow also increased and decreased annually. For example, there were some years, such as 1978 and 1994, when the effects of ground-water irrigation on simulated base flow were zero or small for the North Loup River zone compared with the effects of ground-water irrigation in other years. This indicates that for those years when growing-season effective precipitation was large, causing pumpage for irrigation to be small, there was nearly no effect of ground-water irrigation on simulated base flow. In addition to the indirect effects of climate, the rates for each zone changed with time in response to land-use changes. As the amount of ground-water irrigated lands increased, so did pumpage for irrigation and associated enhanced recharge.

A few of the graphs show negative differences for one or a few short time periods (fig. 32), which indicate that the simulated base flow with irrigation exceeded simulated base flow without irrigation. These negative differences are an artifact caused by the different temporal representations used for pumpage for irrigation as opposed to recharge. Pumpage for irrigation varies annually in response to climate and landuse changes, but recharge was tied only to land-use changes, and did not change with climate. This means that recharge for 


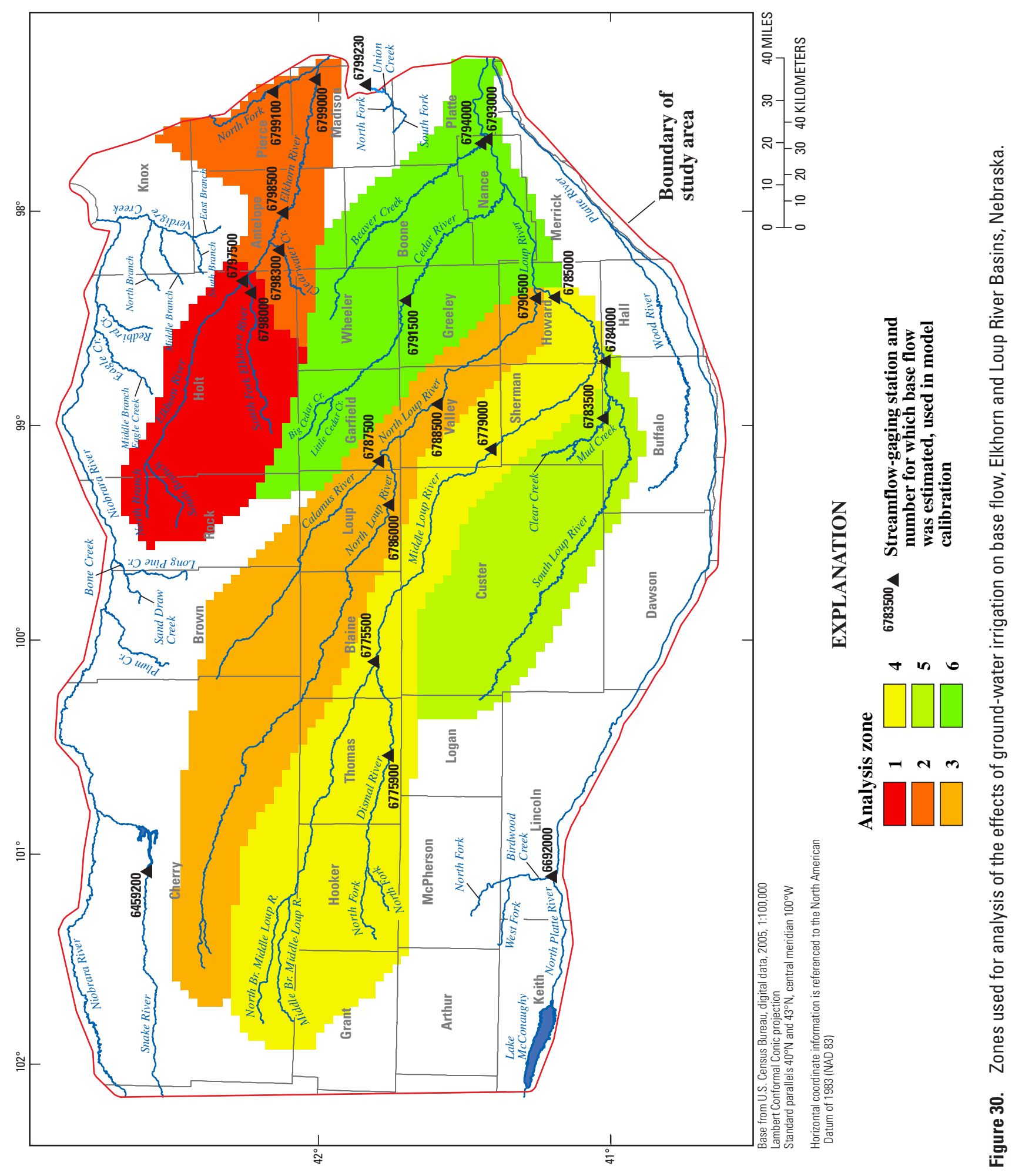




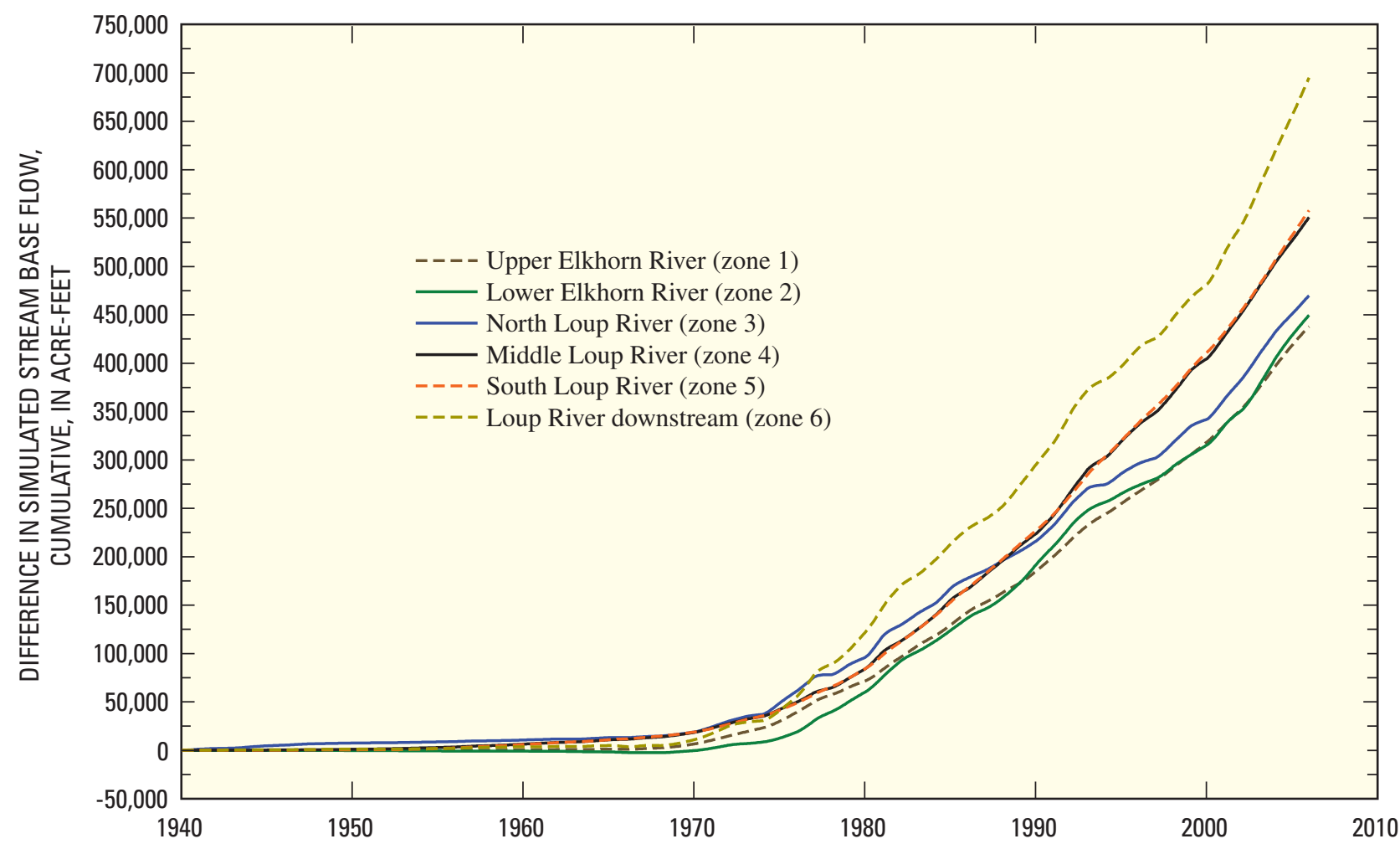

Figure 31. Cumulative effects of ground-water irrigation on simulated base flow, Elkhorn and Loup River Basins, Nebraska, 1940 through 2005. (Differences in simulated base flow for simulations with and without ground-water irrigation are graphed.)

a particular year potentially could increase for a simulation grid cell if more acres were classified as irrigated than for the previous year, while at the same time, if it were a year with increased precipitation during the growing season, pumpage for irrigation would be less than for the previous year. These artifacts are inconsequential for the longer period of the analysis, as they have a small magnitude and do not persist in the results, but rather were confined to a few specific periods, such as for the end of 1965, when the rate of effect was negative for 4 of the 6 zones.

The rates of simulated 2005 base flow by gaged reach and zone number for the baseline and NGWI simulations are listed in table 8. Simulated 2005 base flows for the NGWI simulation were at least as large as simulated 2005 base flows from the baseline simulation, though in most cases the increases were small compared to the overall magnitude of the simulated base flows. The simulated 2005 base flows in the table contrast with the cumulative volume of effects (fig. 31) and the annual rate of effects (fig. 32), as the tabled values are only a sample of the simulated 2005 base flows for the two simulations. The differences between the 2005 base flows for each simulation, summed by the zone numbers given in table 8 , are equivalent to the rates presented in figure 32 for 2005 .

However, because table 8 presents the information about the differences between the two simulations for specific reaches, effects to reaches within each zone can be evaluated. For instance, a casual inspection of the two reaches that zone 1 comprises, the Elkhorn River at Ewing plus the South Fork Elkhorn River at Ewing, show that simulated 2005 base flows for the former reach differ by about 16,500 acre-feet per year (acre-ft/yr) between the two simulations $(45,200$ acre-ft/yr for the baseline simulation, and $61,700 \mathrm{acre}-\mathrm{ft} / \mathrm{yr}$ for the NGWI simulation). In contrast, for the South Fork Elkhorn River at Ewing, the difference in simulated 2005 base flows for the two simulations is only about $1,600 \mathrm{acre}-\mathrm{ft} / \mathrm{yr}(18,400 \mathrm{acre}-\mathrm{ft} / \mathrm{yr}$ for the baseline simulation and 20,000 acre-ft/yr for the NGWI simulation). Therefore, the effects of ground-water irrigation on simulated base flows of the Elkhorn River at Ewing accounted for more than 91 percent of the zone 1 total $(18,100 \mathrm{acre}-\mathrm{ft} / \mathrm{yr})$ for 2005 . Simulated 2045 and 2055 base flows (table 8 ) are discussed respectively in the sections entitled "Results for 2006 through 2045" and "Base-Flow Depletions for 2055," later in this report.

\section{Results for 2006 through 2045}

As described in the "Approach" section for this analysis, two simulations were constructed for hypothetical conditions for 2006 through 2045. One simulation of future conditions used the simulated 2005 water levels from the baseline simulation as starting water levels and the other simulation used the 


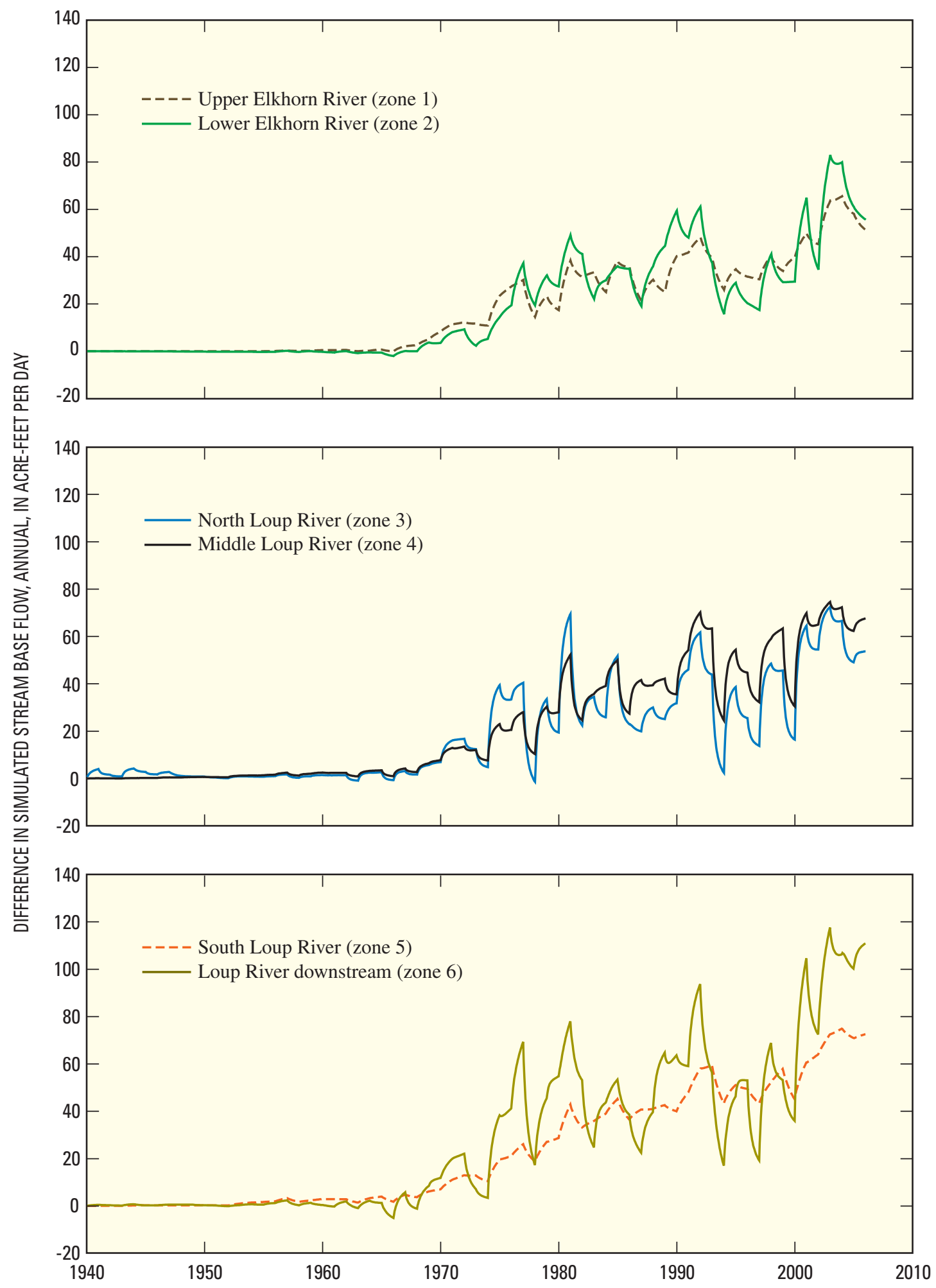

Figure 32. Annual rate of effects of ground-water irrigation on simulated base flow, Elkhorn and Loup River Basins, Nebraska, 1940 through 2005. (Differences in simulated base flow for simulations with and without ground-water irrigation are graphed.) 
Table 8. Comparison of simulated base flow for simulations with and without ground-water irrigation, 2005, 2045, 2055, Elkhorn and Loup River Basins, Nebraska.

[number in parentheses indicate that stream has a net loss of water to the aquifer; no ground-water irrigation (NGWI)]

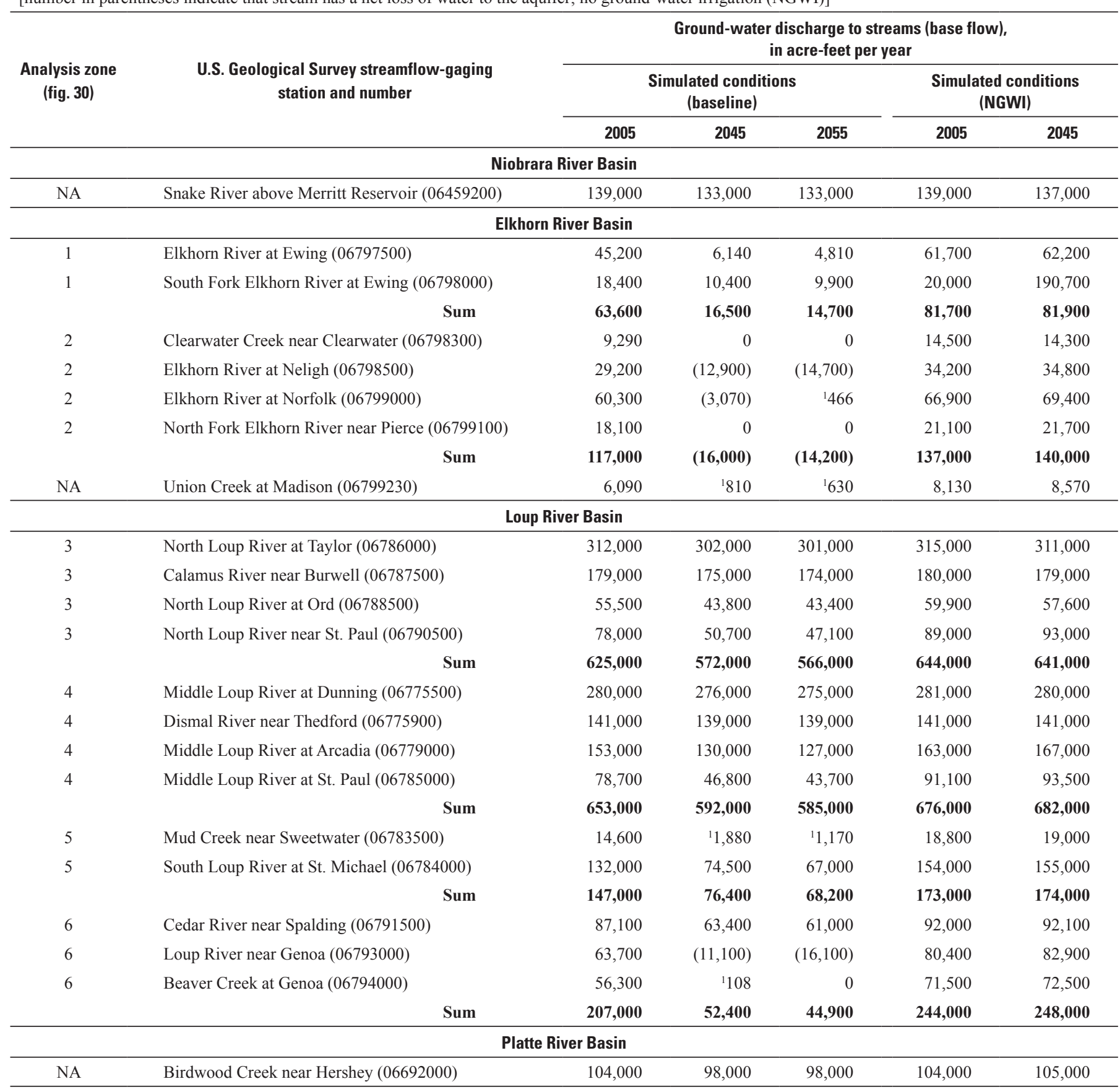

${ }^{1}$ Values are reported to three significant digits, though simulation results have greater uncertainty than tabled values for streams with small base-flow values; values in these cases should be considered to be indicative only of relative magnitude. 
simulated 2005 water levels from the NGWI simulation as starting water levels.

The cumulative effects of ground-water irrigation on simulated base flow for 2006 through 2045 for the same stream zones as analyzed for the 1940 through 2005 period are shown in figure 33 . The plots of cumulative effects are nearly linear for 2006 through 2045 because the same pumpage and recharge were used for the entire simulation period. The largest cumulative effect for 2045 was for the downstream reaches of the Loup River (zone 6) at nearly 6,980,000 acre-ft. This is similar to the results for the 1940 through 2005 analysis, which showed the largest cumulative effect in zone 6 , except that the magnitude of effect on simulated base flows for 2045 was about 10 times larger than it was for 2005. Large effects for the downstream reaches of the Loup River are expected as those reaches are in close proximity to more ground-water irrigated acres than streams in other zones. The smallest effect in 2045 was for the North Loup River (zone 3), at about $2,250,000$ acre-ft, which is about five times the size of the smallest cumulative effect for 2005, which had been simulated for the upper Elkhorn River (zone 1).

The cumulative effects on simulated base flow were nearly identical for four of the zones until almost 2020, at which time the effects diverged, though they remained similar for the remainder of the analysis period (fig. 33). The only zones for which the cumulative effects clearly were larger are the lower Elkhorn River (zone 2) and the Loup River downstream (zone 6). The sum of cumulative 2006 through 2045 effects of ground-water irrigation on simulated base flow was 7,678,000 acre-feet for the Elkhorn River Basin (zones 1 and 2) and was 14,784,000 for the Loup River Basin (zones 3 through 6), more than 7 times larger than the effects predicted for 1940 through 2005.

A similar pattern of larger values for zones 2 and 6 resulted for the daily rates of effect on simulated base flow (fig. 34). Ground-water irrigation effects for zones 1, 3, 4, and 5 were similar throughout the simulation period, increasing in a relatively slow and uniform pattern from 2006 through 2045. Effects for zones 2 and 6 were different (and larger than for the other four zones). The rate of effect for zone 6 increased rapidly from 2006 to 2015, and then increased more slowly until 2045. The rate for zone 2 had a similar pattern to that for zone 6, until around 2036, when the rate of effect abruptly ceased increasing and declined slightly through the remainder of the simulation period.

Generally, rates of effects were four to eight times larger for 2045 than for 2005. Rates from 2006 through 2045 did not show the effects of climate variability because pumpage for irrigation was estimated assuming a constant value of growing-season effective precipitation representative of historically average climatic conditions.

There are a number of reasons why the rate of effects might change. In the simplest sense, curves of the rate of effect through time of a stress on a hydrologic system are expected to approach equilibrium if all other conditions remain constant (Lohman, 1972). As a system approaches equilibrium, the slope of a rate-of-effect curve will decrease with time, causing the curve to flatten and become nearly horizontal. The flattening of any of the curves shown in figure 34 with increasing time is considered an indication of an approach to equilibrium. Curve flattening is not present in figure 32, nor was it expected to appear, because the stresses in that simulation changed annually, whereas for the 2006 through 2045 simulation the stresses were constant through time.

Given that such curves are expected to follow a particular shape, it also means that whenever the shape of such a curve changes abruptly, some aspect of system hydrology has changed. For example, around 2015, as shown in figure 34, the curve for zone 6 (Loup River downstream) abruptly deviated from the smooth curve one might expect based on an informal extrapolation of the part of the curve from 2006 to 2015. In this case, the only definite conclusion that can be made based on the curve alone is that from 2006 to 2015, the effects of ground-water irrigation for zone 6 were being affected by one or more system responses that stopped affecting them after 2015. One system response that could have caused this particular change is evapotranspiration. As water levels in an area decline below the specified evapotranspiration elevation, the rate at which evapotranspiration removes ground water linearly decreases until the water level reaches the extinction depth, at which point evapotranspiration no longer removes ground water. In zone 6 streams during 2006 to 2015 , the effects of ground-water irrigation on simulated base flow could have increased directly as the removal of ground water by evapotranspiration decreased. If the water levels declined below the evapotranspiration extinction depth around 2015, then the linear change in evapotranspiration rate would have stopped affecting the effects of ground-water irrigation on simulated base flow, and the response curve would then most likely have flattened out (again, if all other stresses and responses remain constant).

Reductions in ground-water discharge to evapotranspiration do not explain the absolute flattening or change to a slightly descending rate in the curve for zone 2 after about 2036. However, data in table 8 indicate that simulated 2045 base flows of the baseline simulation for some streams in this zone declined to zero (the North Fork Elkhorn River and Clearwater Creek near Clearwater). For the remaining two reaches, the Elkhorn River at Neligh and Elkhorn River at Norfolk, the simulated 2045 base flows represent a loss of nearly all the base flow gained by streams in zone 1, which is upstream. So, it appears that the curve for zone 2 flattens out because beyond 2036, the rate of effect is dependent only on the amount of simulated base flow routed into this area from upstream, and effects for zone 2 had reached the level where all simulated base flow leaves the stream and returns to the water-table aquifer. For the baseline simulation, the Elkhorn River at Ewing contributed more than 70 percent of the simulated 2005 base flow in zone 1, but it contributed only about 37 percent of the zone 1 simulated 2045 base flow, which had declined overall to only 26 percent of what it had been in 2005 . 


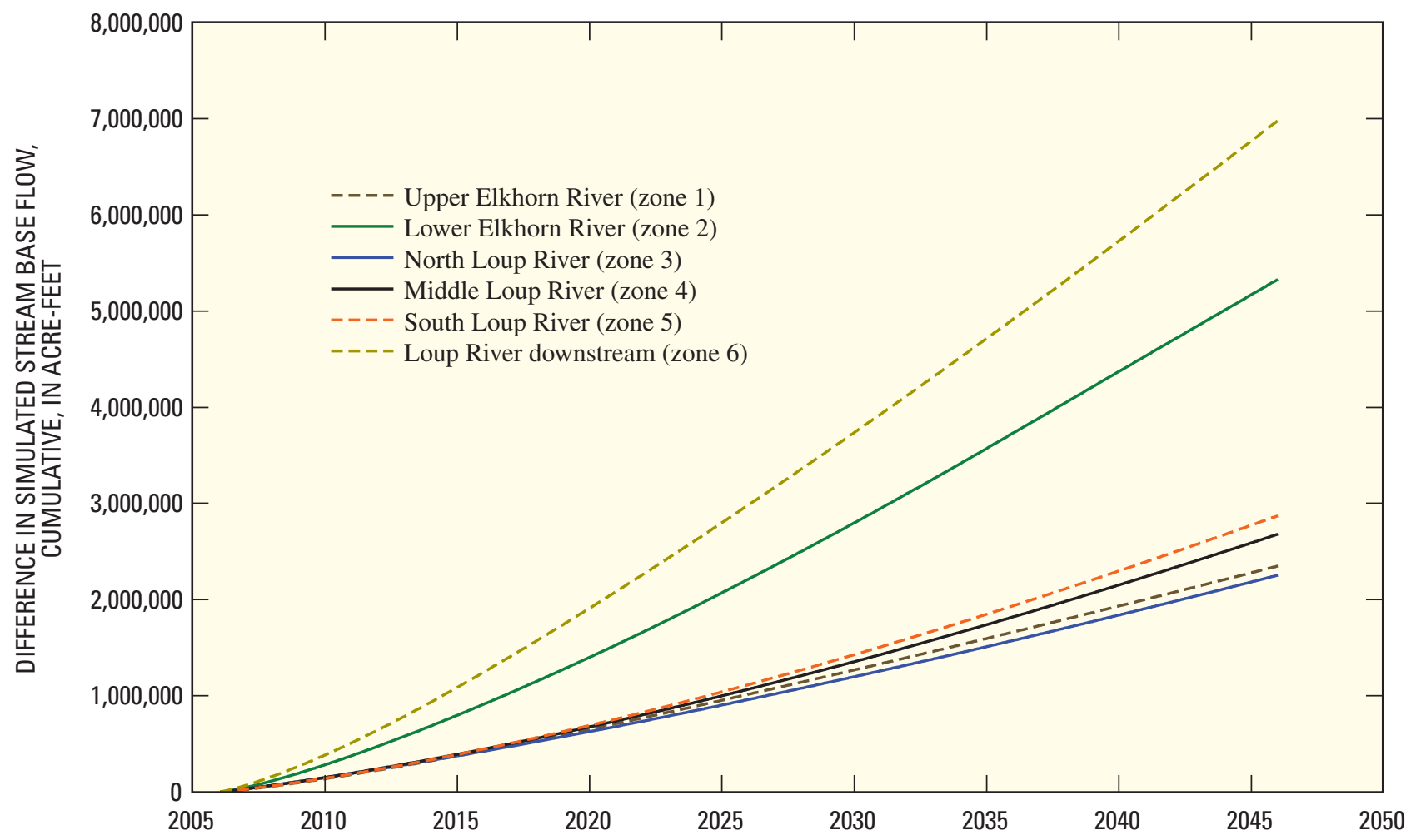

Figure 33. Cumulative effects of ground-water irrigation on simulated base flow, Elkhorn and Loup River Basins, Nebraska, 2006 through 2045.

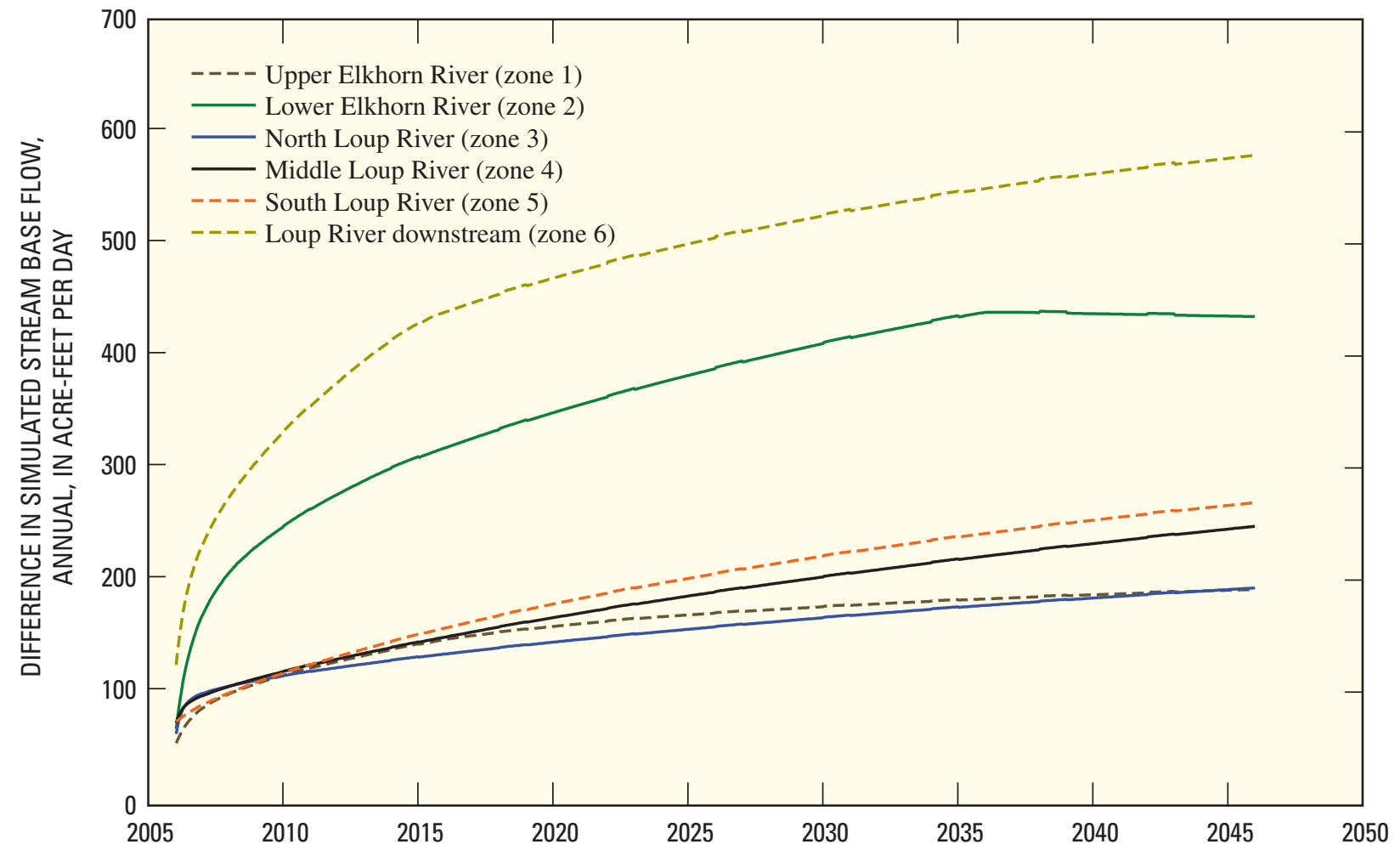

Figure 34. Annual rate of effects of ground-water irrigation on simulated base flow, Elkhorn and Loup River Basins, Nebraska, 2006 through 2045. 
Similar to those in zones 1 and 2, simulated base flows in zones 5 and 6 in the baseline simulation declined from 2005 through 2045, and were 52 percent and 25 percent of simulated 2005 base flows, respectively. For Beaver Creek at Genoa there was no simulated base flow in 2045, and Loup River near Genoa had a net loss of water to the water-table aquifer in 2045.

Conversely, simulated 2045 base flows for zones 3 and 4, while having declined somewhat, were both still about 91 percent of the simulated 2005 base flows. For most stream reaches in zones 3 and 4 (table 8) the declines in simulated base flow from 2005 to 2045 were small in comparison to the overall magnitude of simulated base flows.

Simulated base flows for the NGWI simulation (table 8) generally were about the same in 2045 as they were in 2005 . Many of the decreases and increases during the 2006 through 2045 simulation were small compared to the overall magnitude of simulated base flows. The cause of these minor declines was not further investigated.

The main objective of this analysis was to evaluate the effects of ground-water irrigation on base flow, by comparing base flow from simulations with and without simulation inputs representing ground-water irrigation. For a few streams, simulated 2045 base flow in the simulation with ground-water irrigation declined to zero; once stream base flow has declined to zero, the rate of effects to that stream cannot increase, though pumpage or other withdrawals of ground water could still affect storage, discharge to base flow of other streams, or other hydrologic components dependent on ground-water flow.

\section{Base-Flow Depletion Percentage for a 50-Year Period}

Streamflow depletion percentages for 40 - or 50 -year periods have been the basis for ground-water and surface-water management boundaries in Nebraska (Nebraska Department of Natural Resources, 2005b, 2006). However, existing streamflow depletion maps for the ELM area are based on analytical equations similar to those used by Jenkins (1968). Streamflow depletion as defined by Jenkins (1968) is the number of days a well is pumped until streamflow reductions caused by the well pumping become a predetermined percentage of the pumped volume. Jenkins' (1968) original analytical equation solved for 28 percent streamflow depletion during 40 years. The pumping effects (stream depletion) are composed of (1) additional water that leaks from the streambed to the watertable aquifer because of well pumping, usually referred to as induced seepage, or (2) the capture of ground water that would have discharged to the stream if it had not been captured by the pumping well, usually referred to as captured base flow. In gaining streams, such as many in Nebraska, the part of streamflow depletion caused by captured base flow usually is more than 90 percent of the total streamflow depletion, and induced seepage is only a small part. In contrast, induced seep- age probably would constitute the largest part of streamflow depletions in losing streams.

Though the analytical equations presented by Jenkins (1968) are readily available and simple to implement, they do not account for all the factors that can affect streamflow depletion values. For example, recharge, evapotranspiration, the direction and magnitude of ground-water flow, changes in water-table elevation, and other factors all must be assumed to be negligible to derive the analytical equation. Not all these factors are operative in every location, but all have the potential to affect streamflow depletion caused by pumpage of one additional well. The calibrated Elkhorn-Loup Model, which accounts for many factors affecting streamflow depletion, was used to estimate the percentage of streamflow depletion caused by pumping during a 50 -year period. These results are characterized as base-flow depletion, because that is the part of streamflow simulated by ELM simulations. Streamflow runoff is not represented in the simulations; therefore, depletions to runoff are not represented in the simulation results. This analysis is an appropriate use for the ELM because it concerns a large area and a long time period.

\section{Approach}

To determine the effect of pumpage on base-flow depletion, two simulations were constructed. Both simulations used the calibrated 1940 through 2005 simulation and started with the simulated 2005 water levels, but simulated the period from 2006 through 2055. The first simulation, called the baseline simulation, predicted the effect of maintaining the distribution of 2005 irrigated cropland areas through 2055. Recharge rates were constant during the simulation period and were equal to the recharge rates used in 2005 for the 1940 through 2005 simulation. Pumping rates also were held constant in the baseline simulation and were calculated by subtracting the average (modified) growing-season effective precipitation from 1940 through 2005 from the crop water demand in 2005. All other simulation inputs were the same as those used in the 1940 through 2005 simulation. This simulation essentially was the same as the one used for the baseline simulation for the 2005 through 2045 simulation described in the "Difference in Simulated Base Flow Caused by Ground-Water Irrigation" section of this report, except that for the base-flow depletion analysis, the baseline simulation was configured to run an additional 10 years, through 2055 .

The second simulation, called the pumping-well simulation, also simulated the period from 2006 through 2055, and included the addition of one theoretical well pumped at a constant rate of 1 cubic foot per second $\left(\mathrm{ft}^{3} / \mathrm{s}\right)$. Because the simulation response to the pumping rate of the additional well is nearly linear, the predicted depletion generally is not sensitive to the pumping rate selected for the additional well. Other than the additional well, all inputs were the same as those of the baseline simulation. The reduction in base flow caused by the addition of one pumping well was calculated as the reduction in base flow from the baseline simulation compared 
with the pumping-well simulation during the 50-year period. The volume of that reduction was divided by the volume pumped by the theoretical well to calculate the percentage base-flow depletion caused by that well.

To produce a map displaying the base-flow depletion caused by the addition of the theoretical well throughout the interior of the simulation area required the pumping-well simulation to be repeated for each grid cell for which a result was desired. To determine the base-flow depletion for each grid cell required assigning the theoretical pumping well to that cell, running the pumping-well simulation, and recording the results. The additional well was then moved sequentially to the next grid cell, and the process repeated, using a utility designed to manage these simulations and record the results in a database (CycleWellZB17, Rich Kern, Nebraska Department of Natural Resources, written commun., 2007). The simulated base flow for each of the pumping-well simulations was compared to the simulated base flow in the baseline simulation, and the difference was divided by the pumpage to calculate the percentage base-flow depletion for that grid cell. Changes in simulated base flow caused by the addition of the theoretical well were evaluated only for the Elkhorn and Loup River Basins; depletions caused to the Niobrara or Platte Rivers or their tributaries were not included. The base-flow depletion percentage caused by the additional pumping well in each grid cell was mapped to display the spatial distribution of simulated base-flow depletion (fig. 35).

\section{Base-Flow Depletions for 2055}

In many areas, base-flow depletion for the 50-year future period was greater than 10 percent for wells placed less than 7 or $8 \mathrm{mi}$ from the stream, though considerable variations exist because of the heterogeneity of the natural system represented in the simulation (fig. 35). The distance from streams through which pumpage of one additional well caused depletions of 10 percent of pumpage mostly ranged from 5 to $12 \mathrm{mi}$, though in a few cases even pumpage in the same cell as the stream caused less than a 10 percent depletion.

Pumpage that occurred in the same grid cell as streams or that occurred in a cell next to streams often resulted in a large percentage of base-flow depletion, generally more than 80 percent of pumpage. This can be seen for much of the Loup River system, including the Loup River main stem, and its tributaries, including the Cedar River, North Loup River, and Middle Loup River (fig. 35). However, for the South Loup River and the Dismal River, the depletions were less than 80 percent in the grid cells containing those streams, ranging as low as 60 percent. For the Elkhorn River, depletions were even smaller, tending to be 40 to 60 percent along most of the river, except near the upper end of the Elkhorn River, where most projected depletions were less than 20 percent. For Beaver Creek, most of the depletions for the 2006 through 2055 simulation were less than 20 percent.

Many factors caused base-flow depletions for various streams to be different. Differences in depletions along every stream and across the area are caused by heterogeneity in simulation inputs and by differences in the simulated hydrology of the system. Further, because the simulation does not manufacture water to supply the theoretical well, the water pumped by that well must be balanced by some other change in the system. In some cases, such as for grid cells along parts of the South Loup River and for much of the upper Elkhorn River, the theoretical well reduced the amount of ground water removed by evapotranspiration (figs. 7, 13) instead of depleting base flow, so the base-flow depletion was less than in areas without evapotranspiration of ground water.

In some cases, such as near Beaver Creek and the lower Elkhorn River, and to a small extent near the Dismal River, pumpage of the additional well was at least partially balanced by water-level declines. For the Dismal River, this small decrease in water levels did not have a large effect on the amount of simulated base flow, but it seems that the area where depletions were larger than 10 percent extends further from the Dismal River than from some other streams. However, for Beaver Creek and the lower Elkhorn River, simulated base flows for 2055 either declined considerably from 2005 or base flows were absent.

In the case of Beaver Creek, the lack of simulated base flow in 2055 (table 8) precluded additional pumping wells near that stream from causing further depletions to those simulated base flows by 2055. Simulated base flows of Beaver Creek had declined to 108 acre-ft/yr by 2045, and probably were zero for some period before 2055 (table 8).

In the case of the lower Elkhorn River, simulated base flows indicated a total loss of the flow received from the upstream gaining sections at station 06798500 (table 8). The total loss for this reach occurred in the baseline simulation for 2055, though it was not clear when during 2005 through 2055 it occurred. There also was a total loss of simulated base flow for 2045 in the baseline simulation, but further downstream, at station 06799000 (table 8); the losses occurred mostly upstream from Neligh with additional losses between Neligh and Norfolk. In contrast, in 2055 the simulated base flow was lost upstream from Neligh and no base flow was simulated between Neligh and Norfolk, other than a small gain (466 acre-ft/yr). Regardless of when it occurred, the total loss of base flow in the lower Elkhorn River occurred both in the baseline and pumping-well simulations; therefore, it was not caused primarily by the addition of the theoretical well.

Even without additional work, it is reasonable to infer that if Beaver Creek or the lower sections of the Elkhorn River had more simulated base flow in 2055 (and before), and simulated base flow received from upstream reaches was not lost totally back to the water-table aquifer, that depletions of simulated base flow caused by the theoretical well pumpage in these areas would have been larger. The same would hold true for any stream that had little or no simulated base flow in the baseline simulation. No base-flow depletion can occur if simulated base flow is absent; therefore, base-flow depletion as a percentage of the volume pumped in 50 years declines from the time the stream goes dry until the end of the analysis 


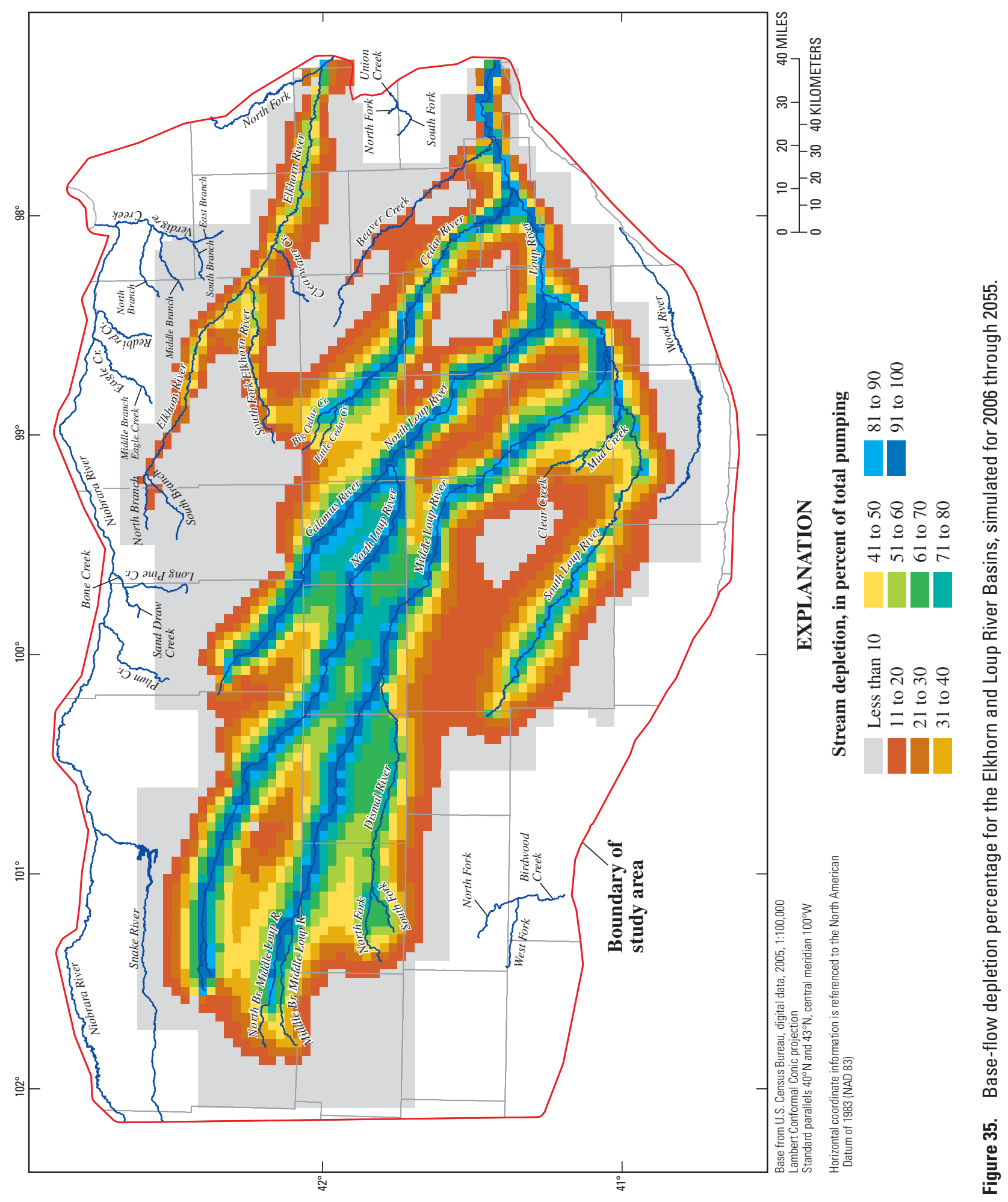


period. If runoff were considered for streams with no base flow, part of that runoff also could be lost to the water-table aquifer, increasing the total streamflow depletion above the base-flow depletion calculated in this analysis.

\section{Simulation Limitations}

Assumptions inherent to MODFLOW simulations are described in the "Numerical Model Construction" section of this report, but these are assumptions common to most studies of this type, and by themselves, those assumptions do not inherently limit the usefulness of the simulation as a tool. Most of the important limitations relate either to data used as simulation inputs or data used to estimate simulation inputs. The simulation of the 1940 through 2005 period predicted simulated water-level changes that were comparable to measured water-level changes, while maintaining an amount of simulated base flow that compared favorably to long-term base-flow estimates; therefore, the balance of the pumpage and recharge inputs was considered to be generally correct. Pumpage for irrigation was constrained using the best measured pumpage data available at the time of the calibration; however, the measured pumpage data correspond only to a short period of record at the end of the simulation period, and represented only a few parts of the study area instead of being uniformly distributed across the entire simulation area. In addition, in the calibrated 1940 through 2005 simulation, estimated pumpage for irrigation and recharge on agricultural lands was dependent on the land-use data. Land-use maps for 1940 through 2005 were based on the best, most reliable data available, but probably still contain errors. Errors in 1940 through 2005 land use would have caused errors in estimated pumpage for irrigation and in calibrated recharge applied to agricultural lands. Moreover, the relations of land use to pumping and land use to recharge also are uncertain.

A detailed analysis of base-flow trends through time was beyond the scope of this study, and no relevant reports of previous base flow-trend analyses by other authors were discovered. However, in the analysis related to Peterson and Carney (2002), no large trends were observed in base flow as defined for that analysis, which studied an area that partially overlaps the ELM area. Therefore, it was assumed at the beginning of the ELM study that no large trends of base-flow changes had occurred in the ELM area during the period of interest, and base-flow estimates were compiled using period of record data. Until an analysis of base-flow trends is completed, the uncertainty associated with this assumption cannot be investigated in a meaningful way and the effects of that uncertainty on the simulation results also is unknown.

Uncertainties in some simulation inputs are not quantifiable, and cause uncertainties in the results of the analyses that used these simulations that also are unquantifiable. As might be expected, the representativeness of the simulation also depends on how representative the past climate conditions and pumpage are of future climate conditions and pumpage. For example, if the 2006 through 2045 simulation is much drier or wetter than average, then the analysis results reported would either understate or overstate the effects of groundwater irrigation and projected base-flow depletions. However, as the amount by which future climate conditions might be drier or wetter than the average of past climate conditions is also unknown, it was considered acceptable to use the average of 1940-2005 climatic conditions to represent hypothetical future conditions.

Furthermore, the simulations documented in this report are considered acceptable, given the input data limitations, simulation assumptions, and resources available at the time of the simulation construction and calibration. However, given the large grid cell spacing ( $2 \mathrm{mi}$ by $2 \mathrm{mi}$ ), these simulations are appropriate only for analyzing regional ground-water management scenarios over spatial scales of multiple counties and time scales of multiple years, and are not for analysis of small areas or short time periods.

\section{Planned Work for Phase Two}

Simulations and analyses reported herein are planned to be updated using components of the Phase Two Elkhorn-Loup Model study. These components include updating the elevation contour map of the base of the water-table aquifer, collecting synoptic streamflow measurements to map gains and losses along stream reaches, construction of a runoff-recharge model to estimate long-term patterns of recharge, geophysical mapping of resistivity patterns in canals, and collecting additional geologic data through test-hole drilling and surface and borehole geophysics. In addition to the new and refined data to be added to the simulations, parameter-estimation techniques (Hill, 1998; Doherty, 2004) will be investigated for phase two simulation calibration, and are expected to provide additional confidence in simulations and analysis, as well as providing quantitative information about calibration and related prediction uncertainty.

The simulated base flows for 1940 and 2005 were compared herein with estimated long-term base flows, but it is preferable to compare simulated and estimated base flows for shorter time periods as well. Accordingly, the simulation will be refined to include this new information, and calibration to base flows over shorter time periods will be evaluated. Analysis completed using the revised simulations will be based at least partially on optimization modeling to analyze water-resource management options.

\section{Summary and Conclusions}

In central and eastern Nebraska, the Elkhorn and Loup Rivers provide surface-water flows for irrigation, recreation, hydropower production, and aquatic life. Outflows from the 
Elkhorn and Loup Rivers also recharge the aquifer used by large municipal water systems that pump ground water near the Platte River. Pumpage for irrigation is vital to agricultural productivity, and hence the livelihood, of the communities in the Elkhorn-Loup Model area. Recent drought (2000-06) has amplified concerns about the long-term sustainability of surface- and ground-water resources in the area, as well as concerns about the effect of ground-water irrigation on streamflow. Further, State legislation was enacted in 2004 to ensure that long-term supplies of ground water and surface water are in balance with long-term demands, and in some cases State and regional agencies must develop integrated management plans to describe how the goal of balancing water demands and supplies will be achieved. The purpose of this report is to document the methodology and results of a simulation of ground-water flow and effects of ground-water irrigation on base flow in the Elkhorn-Loup Model (ELM) area at the completion of its first phase. The goal of the ELM project was to study surface- and ground-water resources in the Elkhorn River Basin upstream from Norfolk, Nebraska, and the Loup River Basin upstream from Columbus, Nebraska and to provide information with which long-term management decisions can be made.

A ground-water flow simulation was constructed and calibrated for the area, using a 2-mi by 2-mi cell size and one layer, to represent the water-table aquifer, comprised of Quaternary-age alluvial deposits and Tertiary-age Ogallala Group deposits. The simulation domain included a 30,800- $\mathrm{mi}^{2}$ area of north-central Nebraska, and simulated the pre-1940 and 1940 through 2005 periods. To calibrate the simulations, simulation outputs were compared with measured water levels, estimated long-term base flow, measured water-level changes for every decade from 1945 to 2005, and measured water-level changes from 1945 to 2005 .

The calibrated simulation was used to analyze the annual and cumulative effects of ground-water irrigation on base flow for the 1940 through 2005 period and for the 2006 through 2045 period. For both time periods, streams most affected were those located in close proximity to more ground-water irrigated acres. Cumulative effects on base flows of six groups of streams in the ELM area through 2005 ranged from 438,000 acre-ft to 695,000 acre-ft. Generally, cumulative effects to stream groups were 5 to 10 times larger for the 2006 through 2045 simulation than for the 1940 through 2005 simulation, and ranged from about 2.3 million acre- $\mathrm{ft}$ up to nearly 7 million acre-ft. For a few streams, simulated 2045 base flow in the simulation with ground-water irrigation declined to zero; in these cases, if the simulated base flow of that stream in the simulation without ground-water irrigation did not change from 2006 to 2045, the effects of ground-water irrigation on base flow cannot further increase for that stream.

The calibrated simulation also was used as the basis for simulation of 2006 through 2055 to predict the base-flow depletion percentage caused by a well throughout most of the interior of the area, because base-flow depletion percentage provides the legal basis for water-management boundaries in
Nebraska. For the Elkhorn and Loup River systems, pumpage of one additional theoretical well resulted in more than 10 percent base-flow depletion if within 7 to $8 \mathrm{mi}$ of most streams, though common distances ranged from 5 to $12 \mathrm{mi}$ among streams. In some locations, pumpage of an additional well in the same grid cell as a stream caused less than 10 percent base-flow depletion, but base-flow depletions usually were more than 80 percent of pumpage when the well was in the same grid cell as the stream. In some areas, depletions were smaller where mitigated by reductions in ground-water discharge to evapotranspiration, or where water-level declines changed the local interaction between surface and ground water. For a few streams, simulated base flow declined substantially from 2006 through 2055; in some of these cases the simulated 2055 base flow was absent. No base-flow depletion occurs if simulated base flow is absent; therefore, base-flow depletion as a percentage of the volume pumped in 50 years declines from the time the stream goes dry until the end of the analysis period. If runoff were considered for streams with no base flow, part of that runoff also could be depleted, increasing the total streamflow depletion above the depletion to base flow alone.

Simulations documented in this report have limitations, as do all tools used to analyze the function of natural systems. Uncertainties in some simulation inputs are not quantifiable, and cause uncertainties in the results of the analyses that used these simulations that also are unquantifiable. However, the simulations documented in this report are as accurate as could reasonably be expected given the input data limitations, simulation assumptions, and resources available at the time of the simulation construction and calibration. Given the large grid cell spacing ( $2 \mathrm{mi}$ by $2 \mathrm{mi}$ ), these simulations are only appropriate for analyzing regional ground-water management scenarios over large areas and long time periods, and are not reliable for analysis of small areas or short time periods. Simulations of the Elkhorn-Loup Model area are planned to be refined through the addition of new data, interpretations, and innovative approaches to analysis during phase two of the study.

\section{References Cited}

Anderson, M.P., and Woessner, W.W., 1992, Applied groundwater modeling-Simulation of flow and advective transport: San Diego, Academic Press, 381 p.

Cannia, J.C., Woodward, Duane, and Cast, L.D., 2006, Hydrostratigraphic units and aquifer characterization report: Nebraska Department of Natural Resources, accessed November 1, 2006, at http://cohyst.dnr.ne.gov/document/ dc012hydro_aquifer_022406.pdf 
Center for Advanced Land Management Information Technologies, 2007, 2005 Nebraska land use patterns: Lincoln, Nebraska, Center for Advanced Land Management Information Technologies, remote-sensing 1:100,000 scale image accessed October 1, 2007, at http://www.calmit.unl. edu/2005landuse/statewide.shtml

Condra, G.E., and Reed, E.C., 1943, The geological section of Nebraska: Nebraska Geological Survey Bulletin (Conservation and Survey Division, University of Nebraska-Lincoln), v. 14, p. 82 .

Conservation and Survey Division, 1996a, Thickness of the principal aquifer: Institute of Agriculture and Natural Resources, University of Nebraska-Lincoln, file wtthick. e00, accessed July 21, 2005, at http://snr.unl.edu/Data/ NebrGIS.asp

Conservation and Survey Division, 1996b, Bedrock geology: Institute of Agriculture and Natural Resources, University of Nebraska-Lincoln, file bedrock.e00, accessed July 21, 2005, at http://snr.unl.edu/Data/NebrGIS.asp

Conservation and Survey Division, 1996c, Configuration of the water table, 1979: Institute of Agriculture and Natural Resources, University of Nebraska-Lincoln, file wtable. e00, accessed August 29, 2005, at http://snr.unl.edu/Data/ NebrGIS.asp\#ConfigurationofWaterTable1979

Conservation and Survey Division, 1997, Topographic regions of Nebraska: Institute of Agriculture and Natural Resources, University of Nebraska-Lincoln, file toporeg.e00, accessed July 21, 2005, at http://snr.unl.edu/Data/NebrGIS.asp

Conservation and Survey Division, 1998, The groundwater atlas of Nebraska: Institute of Agriculture and Natural Resources, University of Nebraska-Lincoln, Resource Atlas No. $4 \mathrm{a}, 44 \mathrm{p}$.

Conservation and Survey Division, 2002, Configuration of the base of the principal aquifer, 1979: Institute of Agriculture and Natural Resources, University of Nebraska-Lincoln, file aqbase.e00, accessed August 29, 2005, at http://snr.unl.edu/Data/NebrGIS.asp

Conservation and Survey Division, 2003, 1995 Water table contours: Institute of Agriculture and Natural Resources, University of Nebraska-Lincoln, file watertable95.e00, accessed February 28, 2003, at http://cohyst.dnr.ne.govi cohyst_preliminarydata.html

Conservation and Survey Division, 2005a, Groundwater-level changes in Nebraska - predevelopment to spring 2005: University of Nebraska map, accessed November 6, 2007, at http://snr.unl.edu/information/GroundwaterMaps.asp
Conservation and Survey Division, 2005b, Transmissivity of the principal aquifer, 2005: Institute of Agriculture and Natural Resources, University of Nebraska-Lincoln, accessed August 5, 2005, at http://snr.unl.edu/Data/NebrGIS.asp

Conservation and Survey Division, 2005c, Specific yield of the principal aquifer, 2005: Institute of Agriculture and Natural Resources, University of Nebraska-Lincoln, accessed August 3, 2005, at http://snr.unl.edu/Data/NebrGIS.asp

Conservation and Survey Division, 2005d, Till: Institute of Agriculture and Natural Resources, University of Nebraska-Lincoln, accessed July 14, 2005, at http://snr.unl.edu/ Data/NebrGIS.asp

Conservation and Survey Division, 2006, Testhole database: Institute of Agriculture and Natural Resources, University of Nebraska-Lincoln, accessed October 30, 2006 at http://snr.unl.edu/Data/NebrGIS.asp

Doherty, J.E., 2004. PEST — model-independent parameter estimation: user's guide, 5th ed. 333 p., accessed December 21, 2004, at http://www.sspa.com/PEST

Eisenhauer, D.E., Martin, D.L., and Hoffman, G.J., 1996, Irrigation system performance, in Irrigation systems management MSM452/852 - Class notes: Lincoln, University of Nebraska, 38 p.

Environmental Modeling Systems, Inc., 2007, GMS 6.0: software release August 7, 2007, accessed August 30, 2007, at http://www.ems-i.com/

Fetter, C.W., 1994, Applied hydrogeology (3d. ed.): Upper Saddle River, N.J., Prentice Hall, 691 p.

Harbaugh, A.W., 1990, A computer program for calculating subregional water budgets using results from the U.S. Geological Survey modular three-dimensional ground-water flow model: U.S. Geological Survey Open-File Report 90-392, $46 \mathrm{p}$.

Harbaugh, A.W., 2005, MODFLOW-2005, the U.S. Geological Survey modular ground-water model - the ground-water flow process: U.S. Geological Survey Techniques and Methods, book 6, sect. A, chap. 16, 253 p.

Harbaugh, A.W., Banta, E.R., Hill, M.C., and McDonald, M.G., 2000, MODFLOW-2000, the U.S. Geological Survey modular ground-water model - user guide to modularization concepts and the ground-water flow process: U.S. Geological Survey Open-File Report 00-92, 121 p.

Hill, M.C., 1998, Methods and guidelines for effective model calibration: U.S. Geological Survey Water-Resources Investigation Report 98-4005, 97 p.

Hill, M.C., 2006, The practical use of simplicity in developing ground water models: Ground Water, v. 44, no. 6, p. $775-781$. 
Jenkins, C.T., 1968, Computation of rate and volume of stream depletion by wells: Washington, D.C., U.S. Geological Survey Techniques of Water-Resources Investigations, book 4, chap. D1, 17 p.

Keech, C.F., and Bentall, Ray, 1971, Dunes on the plainsthe Sand Hills region of Nebraska: Lincoln, Conservation and Survey Division, Institute of Agriculture and Natural Resources, University of Nebraska-Lincoln, Resource Report No. 4, 18 p.

Lohman, S.W., 1972, Ground-water hydraulics: U.S. Geological Survey Professional Paper 708, 70 p.

Luckey, R.R., and Cannia, J.C., 2006, Groundwater flow model of the western model unit of the Nebraska Cooperative Hydrology Study (COHYST) area: Nebraska Department of Natural Resources accessed November 1, 2006, at http://cohyst.dnr.ne.gov/adobe/dc012WMU_ GFMR_060519.pdf

McDonald, M.G., and Harbaugh, A.W., 1988, A modular three-dimensional finite-difference ground-water flow model: U.S. Geological Survey Techniques of Water-Resources Investigations, book 6, chap. A1, 588 p.

National Climatic Data Center, 2006, Climate division precipitation data: Asheville, North Carolina, National Climate Data Center, accessed July 31, 2006, at http://www.cdc. noaa.gov/USclimate/Data/

Nebraska Department of Natural Resources, 1997, Digital elevation model: Nebraska Department of Natural Resources, accessed November 28, 2005, at http://www.dnr.ne.gov/ databank/dem.html

Nebraska Department of Natural Resources, 2005a, Registered well database: Nebraska Department of Natural Resources, accessed September 26, 2005, at http://dnrdata.dnr.ne.gov/ wellssql/

Nebraska Department of Natural Resources, 2005b, 2006 Annual evaluation of availability of hydrologically connected water supplies: Nebraska Department of Natural Resources, accessed February 1, 2006, at http://dnr.ne.gov/ LB962/AnnualReport/AnnualReport_2006.html

Nebraska Department of Natural Resources, 2006, 2007 Annual evaluation of availability of hydrologically connected water supplies: Nebraska Department of Natural Resources, accessed February 1, 2007, at http://dnr.ne.gov/ LB962/AnnualReport_2007/AnnualReport2007.pdf

Nebraska Department of Natural Resources, 2007, LB962 enacted into law: Nebraska Department of Natural Resources, accessed November 4, 2007, at $h t t p: / / w w w . d n r$. ne.gov/watertaskforce/LB962/LB962SCREEN.pdj
Nebraska Department of Natural Resources, 2008, Nebraska surface water rights data retrieval: Nebraska Department of Natural Resources, accessed May 26, 2008, at http://dnrdata.dnr.ne.gov/SWRCombined/ SelectSearchOptions.aspx

Nebraska Natural Resources Commission, 1998, Estimated water use in Nebraska, 1995: Nebraska Natural Resources Commission, State Water Planning and Review Process, $47 \mathrm{p}$.

Peterson, S.M., and Carney, C.P., 2002, Estimated groundwater discharge to streams from the High Plains aquifer in the Eastern Model Unit of the COHYST study area for the period prior to major groundwater irrigation: Nebraska Department of Natural Resources, accessed March 4, 2002, at http://cohyst.dnr.ne.gov/adobe/dc012EMU_baseflw_02. $p d f$

Prudic, D.E., 1989, Documentation of a computer program to simulate stream-aquifer relations using a modular, finitedifference, ground-water flow model: U.S. Geological Survey Open-File Report 88-729, 113 p.

Reilly, T.E., 2001, System and boundary conceptualization in ground-water flow simulation: U.S. Geological Survey Techniques of Water-Resources Investigations, book 3, chap. B8, 26 p.

Reilly, T.E., and Harbaugh, A.W., 2004, Guidelines for evaluating ground-water flow models: U.S. Geological Survey Scientific Investigations Report 2004-5038, 30 p.

Scanlon, B.R., Reedy, R.C., Stonestrom, D.A., Prudic, D.E., and Dennehy, K.F., 2005, Impact of land use and land cover change on groundwater recharge and quality in the southwestern U.S.: Global Change Biology, v. 11, p. $1,577-1,593$.

Szilagyi, Jozsef, Harvey, F.E., and Ayers, J.F., 2003, Regional estimation of base recharge to ground water using water balance and a base-flow index: Ground Water, v. 41, no. 4, p. 504-513.

University of Nebraska, 1990, Evapotranspiration (ET) or crop water use: Lincoln, University of Nebraska, Cooperative Extension, NebGuide G90-992-A, accessed January 9, 2007, at http://www.p2pays.org/ref/20/19769.htm

University of Nebraska, 2002, Crop water use in western Nebraska: Lincoln, University of Nebraska, Cooperative Extension, NebGuide G1465, accessed January 9, 2007, at http://www.ianrpubs.unl.edu/epublic/pages/publicationD. jsp? publicationId $=248$ 
U.S. Department of Agriculture, 1986, Soil Conservation Service: Technical Release 55, Urban hydrology for small watersheds: U.S. Department of Agriculture, accessed March 19, 2007, at http://www.info.usda.gov/CED/ftp/CED/ tr55.pdf

U.S. Department of Agriculture, 2006, USDA - National Agricultural Statistics Service's 1:100,000-scale 2005 cropland data layer, a crop-specific digital data layer for Nebraska, 2006: U.S. Department of Agriculture, National Agriculture Statistics Service, raster digital data CD-ROM.

U.S. Department of Agriculture, variously dated, Census of agriculture: U.S. Department of Agriculture data, electronic data accessed May 8, 2006, at http://www.agcensus.usda. gov/

U.S. Environmental Protection Agency, 2003, Level III and IV ecoregions of the continental United States: U.S. Environmental Protection Agency, vector digital data, accessed November 28, 2007, at http://www.epa.gov/wed/pages/ ecoregions.htm

U.S. Fish and Wildlife Service, 2005, National wetlands inventory-Wetlands geodatabase: U.S. Fish and Wildlife Service, accessed November 4, 2005, at http://wetlandsfws. er.usgs.gov/NWI/
U.S. Geological Survey, 2005, USGS ground-water data for Nebraska: U.S. Geological Survey data, accessed August 1, 2005, at http://waterdata.usgs.gov/ne/nwis/gw

U.S. Weather Bureau, 1959, Evaporation maps for the United States: U.S. Weather Bureau Technical Paper 37, plate 2, digital data available at http://cohyst.dnr.ne.gov/ cohyst_preliminarydata.html

Water and Climate Center of the Natural Resources Conservation Service, 2000, Central United States average annual precipitation, 1961-90: Lincoln, Nebraska Department of Natural Resources, accessed November 26, 2007, at http://cohyst.dnr.ne.gov/cohyst_preliminarydata.html\#weat

Wilson, J.D., and Naff, R.L., 2004, The U.S. Geological Survey modular ground-water model-GMG linear equation solver package documentation: U.S. Geological Survey Open-File Report 2004-1261, 47 p.

Woodward, D.E., Hawkins, R.H., Jiang, Ruiyun, Hjelmfelt, A.T., Van Mullem, J.A., and Quan, Q.D., 2002, Runoff curve number method - examination of the initial abstract ratio, in Federal Interagency Hydrologic Modeling Conference, 2d, Las Vegas, Nev., 2002, Proceedings: Reston, Va., U.S. Interagency Advisory Committee on Water Data, CD-ROM. 
Publishing support provided by:

Rolla Publishing Service Center

For more information concerning this publication, contact: Director, USGS Nebraska Water Science Center

5231 South 19 Street

Lincoln, NE 68512

(402) 328-4100

Or visit the Nebraska Water Science Center Web site at: http://ne.water.usgs.gov 

